\title{
Scoping Review \\ Supporting decision-making on allocation of ICU beds and ventilators in pandemics
}

\author{
Magnolia Cardona, PhD, MBBS, ${ }^{1,2^{*}}$ Claudia C. Dobler MD, PhD, ${ }^{1,3,6}$ Eyza Koreshe MPH, \\ BSc, ${ }^{4}$ Daren K Heyland, MD, FRCPC ${ }^{5}$ Rebecca Nguyen, ${ }^{6}$ Joan P.Y. Sim, ${ }^{6}$ Justin Clark, BA, ${ }^{1}$ \\ Alex Psirides MBBS, FCICM. ${ }^{7}$
}

\author{
Affiliations \\ ${ }^{1}$ Institute for Evidence-Based Healthcare, Bond University Gold Coast, Queensland, Australia \\ ${ }^{2}$ Gold Coast University Hospital, Southport, Queensland, Australia \\ ${ }^{3}$ Evidence-Based Practice Center, Robert D. and Patricia E. Kern Center for the Science of \\ Health Care Delivery, Mayo Clinic, Minnesota, USA \\ ${ }^{4}$ Boden Institute, University of Sydney, NSW, Australia \\ ${ }^{5}$ Department of Critical Care Medicine, Queens University, Kingston, Ontario, Canada \\ ${ }^{6}$ The University of New South Wales, South Western Sydney Clinical School, NSW Australia \\ ${ }^{7}$ Intensive Care Unit, Wellington Regional Hospital, Wellington, New Zealand
}

\begin{abstract}
As the world struggles with the COVID-19 pandemic, health service demands have increased to a point where healthcare resources may prove inadequate to meet demand. Guidelines and tools on how to best allocate intensive care beds and ventilators developed during previous epidemics can assist clinicians and policymakers to make consistent, objective and ethically sounds decisions about resource allocation when healthcare rationing is inevitable. This scoping review of 62 published guidelines, triage protocols, consensus statements and prognostic tools from crisis and non-crisis situations sought to identify a multiplicity of objective factors to inform healthcare rationing of critical care and ventilator care. It also took ethical considerations into account. Prognostic indicators and other decision tools presented here can be combined to create locally-relevant triage algorithms for clinical services and policy makers deciding about allocation of ICU beds and ventilators during a pandemic. Community awareness of the triage protocol is recommended to build trust and alleviate anxiety among the public. This review provides a unique resource and is intended as a discussion starter for clinical services and policy makers to consider formalising an objective triage consensus document that fits the local context.
\end{abstract}


medRxiv preprint doi: https://doi.org/10.1101/2020.09.20.20198184; this version posted September 23 , 2020. The copyright holder for this preprint (which was not certified by peer review) is the author/funder, who has granted medRxiv a license to display the preprint in All rights reserved. No reuse allowed without permission.

Keywords: intensive care; ventilator; COVID-19 pandemic; decision-making; healthcare rationing; triage; review.

Take-home message: An evidence-based catalogue of objective variables from 62 published resources tested in crisis and non-crisis situations can help clinicians make locally relevant triage decisions on ICU and ventilator allocation in inevitable COVID-19 health rationing.

\section{Supporting decision-making on allocation of ICU beds and ventilators in pandemics}

\section{Background}

The COVID-19 pandemic stretched hospital resources to their limits and beyond in Italy, Spain, England, France, Brazil and the United States [1].Countries and cities that were not affected too badly initially may experience ongoing epidemic waves, and some countries are likely to reach maximum hospital capacity in the near future. A number of countries have faced a shortage of ventilators for COVID-19 patients due to pre-pandemic deficiency. There has been demand for additional care sites and health care to handle a surge in COVID-19 patients. Reported hospitalisation rates are age related, ranging from 0-1\% (in people aged 29 years or younger) to $80 \%$ (in people aged $80+$ years) [2]. Of hospitalised patients, 4.6 to $45.9 \%$ have required treatment in the ICU [2-4]. Of all those requiring critical care, $75 \%, 76 \%$ and $88 \%$ ended up receiving treatment on a ventilator in the UK, the USA and Italy respectively [5-7]. The length of stay in ICU for COVID-19 patients on ventilators has been longer than in non-crisis periods (median 10 days IQR between 8-14 days in Italy)[7] and median 18 days IQR 9-28 in USA) [8]. Over a quarter (26 to 38\%) of those admitted to ICU have died [3,6,7], and overall, people older than 75 years have experienced the highest COVID-19 mortality rates (from $33.5 \%$ in UK, to $75.5 \%$ in France) [8,9].

ICUs have some capacity to respond to increased demand by surging ICU beds, repurposing hospital spaces, purchasing additional ventilators and hiring and/or training the health 
medRxiv preprint doi: https://doi.org/10.1101/2020.09.20.20198184; this version posted September 23 , 2020. The copyright holder for this preprint (which was not certified by peer review) is the author/funder, who has granted medRxiv a license to display the preprint in All rights reserved. No reuse allowed without permission.

workers needed to care for critically ill patients. However, with rapidly increasing and sustained demand such measures might be insufficient, and the need for resources may rapidly exceed capacity. In this situation, healthcare systems need to have evidence-based, equitable, and publicly defensible policies in place on how to ration potentially life-saving treatments [10,11]. Rules to guide allocation of life sustaining treatments will need to incorporate ethical considerations such as social justice, non-prejudice, prevention of preferential treatment of population subgroups, and be transparent to clinicians and the public to prevent moral distress and outrage.

While many health services have ICU admission policies in place for routine care, a recent survey of US services found vast heterogeneity in ventilator triage policies for COVID19. Policies were based (exclusively or in combination) on subjective perceptions of benefits to patients and medical need, ethical considerations, and objective clinical scoring systems [12]. A common gap in these recommendations is the lack of integration of patient values and treatment preferences [13].

We conducted a scoping review of publications that provide prognostic prediction tools or models, and/ or objective triage recommendations which can inform allocation of ICU beds and/or ventilators. The specific objectives were:

1. To identify criteria for ICU admission and ventilator allocation used in epidemic situations as well as during routine care

2. To identify prognostic tools used in patient care during and outside epidemic situations that can potentially enhance confidence in decision-making about resource allocation during the COVID-19 pandemic; and

3. To discuss applicability of these tools for ICU triage in future global emergencies

\section{Methods}

For this scoping review, we searched the databases Medline and Embase on $1^{\text {st }}$ May 2020 for English language articles published since $1^{\text {st }}$ January 2002 (the year in which a SARS outbreak emerged) [14]. Additionally, we manually searched institutional websites of professional intensive care societies, reference lists of systematic reviews, pandemic guidelines from World Health Organization and Centre for Disease Control, and consulted 
medRxiv preprint doi: https://doi.org/10.1101/2020.09.20.20198184; this version posted September $23,2020$. The copyright holder for this preprint (which was not certified by peer review) is the author/funder, who has granted medRxiv a license to display the preprint in All rights reserved. No reuse allowed without permission.

with experts in the field (AP, CD, DH). Details of the full search strategy are shown in Supplement 1, Table S1.1

\section{Inclusion criteria}

We included studies that described patient characteristics and clinical or laboratory parameters/algorithms to facilitate healthcare triage (I). Settings included were hospital wards, emergency departments, and ICUs. To be eligible for inclusion, studies had to report either the accuracy of a prognostic tool (area under the receiver operating characteristics curve [AUROC], or sensitivity/specificity), the validity of a prognostic tool, or significant correlation between a prognostic tool and clinical outcomes (mortality or complication rates) using odds ratios and 95\% confidence intervals (CI). Target populations (P) were adults or children presenting to hospital during pandemic or non-crisis periods. We included cohort studies, retrospective analyses with large sample sizes (>100 patients), case-control studies, position statements of clinical colleges or professional societies, and consensus documents or guidelines. Selected articles were classified as applicable during an epidemic or applicable to routine care (i.e non-crisis situations).

\section{Exclusion criteria}

We excluded pre-prints; recommendations based on i) subjective clinical judgments only; ii)test result cut-off points that were not validated or at least statistically significantly associated with clinical outcomes; iii) disease-specific scores (e.g. for blood cancers or traumatic brain injury); that were irrelevant to COVID-19; recommendations related to injury in mass casualties; modelling studies; studies with a small sample size $(<100)$; conference abstracts with insufficient data on association/prediction performance; poor performing algorithms; publications in non-Western health systems; and reports with a focus on logistics, ethics of surge capacity.

\section{Outcomes}

Our outcomes of interest (O) were performance of algorithms or individual clinical or laboratory factors in predicting patient outcomes, such as in-hospital, 30-day, 90-day, or 1year mortality. Comparators (C) for the validation studies were any other algorithm or 
medRxiv preprint doi: https://doi.org/10.1101/2020.09.20.20198184; this version posted September $23,2020$. The copyright holder for this preprint (which was not certified by peer review) is the author/funder, who has granted medRxiv a license to display the preprint in All rights reserved. No reuse allowed without permission.

laboratory test used by authors, or confirmation of outcomes at discharge or follow-up as specified.

\section{Data extraction and synthesis}

Dyads of reviewers (MC, EK, RN, JS), independently extracted the following study information using a standardized data extraction sheet: author, year of publication, study country, publication type, characteristics of target population disease-specific information), whether pandemic or routine care, type of triage decision (for admission to ICU, discharge from ICU), decision algorithms, and characteristics of risk prediction tools. All discrepancies were discussed within the dyads until consensus was achieved. Algorithm components and variables were presented in tabular form according to source from crisis or non-crisis situation, and whether they were used in intensive care, emergency departments or hospital wards. No meta-analysis was attempted, as this was a scoping review.

\section{Results}

Sixty-two publications relating to 20 countries (eight studies covered multiple countries) met the eligibility criteria: Seven pandemic guidelines/consensus papers/frameworks,[11,15-20] Nine pandemic triage factors/decision algorithms, [8,21-28] and 46 algorithms, prognostic tools or guidelines for non-crisis care met our inclusion criteria: 19 for routine ICU care [2947], 21 for routine emergency department care [48-68], and six for general ward care [47,69-73]. The screening process is illustrated in Figure 1, and reasons for exclusion of studies are presented in Supplement 1, Table S1.2.

\section{<Figure 1. PRISMA diagram illustrating inclusions and exclusions> about here}

The target age groups for the pandemic publications were predominantly adults of all ages admitted to ICU, whereas the routine care algorithms included patients in emergency departments or ICU, and three were exclusively for babies and children [32,34,72]. Supplement 1, Table S1.3 summarises the target populations, study types, and context for pandemic situations, and Table S1.4 shows the corresponding information for routine care. 
medRxiv preprint doi: https://doi.org/10.1101/2020.09.20.20198184; this version posted September 23 , 2020. The copyright holder for this preprint (which was not certified by peer review) is the author/funder, who has granted medRxiv a license to display the preprint in

All rights reserved. No reuse allowed without permission.

Fourteen of the pandemic-related articles and 8 of the routine care papers included factors that applied to patients with pneumonia. Other conditions to which risk prediction tools/factors were applied included influenza, sepsis, acute injuries due to natural disasters in adults and children, exacerbation of chronic obstructive pulmonary disease, chronic kidney disease and heart failure. Most of the pandemic-related publications suggested criteria for ICU admission, ICU discharge or ventilator allocation, although not all addressed all three questions.

\section{Domains used for decision-making}

A summary of references for recommendations to consider in the decision to escalate care, admit individuals to ICU, and allocate ventilators is presented in Table 1. One domain for decision making included variables and scores to determine patients' need for higher-level care (column A) to patients who may not yet be in ICU, ventilated or receiving other organ support but may do so later (Table 1, column A). Another domain for decision-making included predictors for patients who stand to benefit from ICU care or mechanical ventilation the most and should be prioritised (Table 1, column B).

The Sequential Organ Failure Assessment (SOFA) score and its variants was the most widely used (or reported) for both ICU admission and discharge criteria, as well as to recommend ventilator allocation or removal.

Patients who stand to benefit the most from ICU admission typically suffer from a critically severe, treatable and potentially reversible deterioration of health. ICU treatment should also be consistent with the values and preferences of the patient [13,74]. When patients' are deteriorating despite ongoing ICU care, withdrawal of life-sustaining therapies, and transfer to ward and palliative care has to be considered. This process is known as 'reverse triage' [75] and variables to facilitate these decisions are listed in Table 1, column C. Withholding or withdrawing treatments must include discussions with the patient (if possible) and their family. Ideally during pandemic triage the possibility of future deterioration and need to discharge from ICU later should already be discussed on admission to ICU. 
medRxiv preprint doi: https://doi.org/10.1101/2020.09.20.20198184; this version posted September $23,2020$. The copyright holder for this preprint (which was not certified by peer review) is the author/funder, who has granted medRxiv a license to display the preprint in All rights reserved. No reuse allowed without permission.

Multiple studies investigated predictors for mortality in the ensuing weeks and months after ED or ICU admission to inform decision-making, mostly in non-pandemic situations (Table 1, columns D and E). These prediction models can assist clinicians and patients in the decision-making about the appropriateness of ICU care by providing information about the expected recovery (or likely downward trajectory) following ICU admission and/or ventilator treatment $[39,76,77]$.

\section{Variables and prognostic factors used for decision-making in pandemic situations}

Amongst the sixteen pandemic-related publications, several expert consensus documents outlined factors that inform the allocation of ICU care and ventilator treatment (Table 2). The usual criteria for requiring critical care interventions applied such as refractory hypoxaemia, respiratory acidosis, evidence of impending respiratory failure, shock, requiring, vasopressor or inotropic support, decreased urinary output, evidence of organ failure, and altered level of consciousness.

The SOFA, qSOFA, and mSOFA score cut-offs were used to either determine priority for ICU or ventilator access or removal from a ventilator and/or discharge from ICU in futile situations. Likewise, the AGILITIES score and Simple Triage Scoring (STSS) for adults, the Pediatric Logistic Organ Dysfunction 2 (PELOD) triage score, the COVID-19 clinical risk score, and the Community Assessment Tools (CATs) criteria for adults and children were used to prioritise ICU admission or recommend ICU discharge due to a lack of benefit.

Age was a variable in six of the 15 predictive approaches for pandemic situations $[8,18,19,25,27,78]$. Two studies outlined criteria for patients who do not require organ support or ICU because they are below the critical illness threshold [11,23]. 
Table 1. Evidence-based variables and scores for decision-making about allocation of ICU care and ventilators based on predicted outcomes (during pandemics and routine care)

\begin{tabular}{|c|c|c|c|c|c|}
\hline Factors and scores for decision-making & $\begin{array}{c}\text { A) } \\
\text { Predicts need for } \\
\text { increased care } \\
\text { resources/ ICU } \\
\text { care }\end{array}$ & $\begin{array}{c}\text { B) } \\
\text { High or intermediate } \\
\text { priority for ICU and } \\
\text { ventilator allocation } \\
\text { based on potential } \\
\text { benefit }\end{array}$ & $\begin{array}{c}\text { C) } \\
\text { Recommends Not for } \\
\text { ICU or discharge from } \\
\text { ICU or exclude from } \\
\text { ventilator }\end{array}$ & $\begin{array}{c}\text { D) } \\
\text { Predicts } \\
\text { in-hospital death }\end{array}$ & $\begin{array}{c}\text { E) } \\
\text { Predicts } \\
\text { ICU discharge death or } \\
\text { poor function } \\
\mathbf{3 0 , 9 0 , 3 6 5 \mathrm { d }}\end{array}$ \\
\hline \multicolumn{6}{|l|}{ OTHER RECOMMENDATIONS } \\
\hline Guidelines, Consensus & & {$[16,18,20,23,79,80]$} & {$[11,15-19,79,80]$} & & \\
\hline Triage scores, reviews & [21] & {$[3,20,23,27-29,81]$} & {$[10,22,28,39,47,81]$} & {$[8,27]$} & {$[73,77]$} \\
\hline \multicolumn{6}{|l|}{ SCORES / INDICES } \\
\hline SOFA/qSOFA/mSOFA & {$[21,49]$} & {$[3,11,15,17,18,23]$} & {$[11,15,17,21-24]$} & {$[17,22,24,51]$} & [29] \\
\hline $\begin{array}{l}\text { ICU scoring: APACHE II, PIM2, PELOD, } \\
\text { ProVent14, SAPS II, SMART-COP, SI, STSS, } \\
\text { SMS-ICU }\end{array}$ & $\begin{array}{c}{[21,37,40,47,56} \\
58]\end{array}$ & {$[10,36,45,46]$} & {$[39,45,46]$} & $\begin{array}{c}{[30,33-36,38,41-} \\
45,47,56,58,62,82]\end{array}$ & {$[31,40,41,58]$} \\
\hline $\begin{array}{l}\text { Other routine scores: ALT, EWS, CURB65, } \\
\text { CriSTAL, HOTEL, IDSA/ATS, mBTS, MPM, } \\
\text { NIVO, REMS, SCAP, SCS, TIMM, WPS }\end{array}$ & $\begin{array}{c}{[37,47,54,56,58} \\
59,62]\end{array}$ & & [47] & {$[53,55,57,71,72]$} & $\begin{array}{c}{[37,50,53,54,58,60,61} \\
65,69,71]\end{array}$ \\
\hline \multicolumn{6}{|l|}{ CLINICAL \& LABORATORY VARIABLES } \\
\hline Sepsis & [49] & & & {$[49,51]$} & [70] \\
\hline Shock Index & {$[21,56]$} & & & {$[21,27,55,56]$} & \\
\hline Hypotension or requires vasopressors & {$[37,49,54]$} & & [39] & {$[38,51]$} & [69] \\
\hline $\begin{array}{l}\text { Abnormal respiratory rate, respiratory failure, } \\
\text { Low } \mathrm{SpO}_{2} \text {, or pneumonia }\end{array}$ & {$[21,37,54]$} & [19] & {$[10,47]$} & {$[27,47]$} & {$[37,58,69]$} \\
\hline Arterial Lactate & & & & {$[64,83,84]$} & {$[48,63]$} \\
\hline High creatinine or end-stage renal disease & & & {$[39,67]$} & {$[38,67]$} & {$[48]$} \\
\hline \multicolumn{6}{|l|}{ CLINICAL CONDITIONS, DEMOGRAPHICS } \\
\hline GCS/altered mental state & {$[27,37,49,54]$} & & & {$[27,38,47]$} & {$[38,60,69]$} \\
\hline Cardiac arrest or resuscitation & & {$[16,17]$} & & {$[38,67]$} & \\
\hline End-stage organ failure & & [19] & & & \\
\hline Advanced malignancy & & [17] & & {$[33,38]$} & [65] \\
\hline Frailty/aged care residency/prior admission/obesity & & [19] & & {$[47,52,68]$} & {$[60,65]$} \\
\hline Physical functioning, quality of life & & & & & {$[32,77]$} \\
\hline Age (life cycle) & {$[27,54]$} & [17-19] & [39] & {$[36,39,56,65]$} & {$[60,65,69]$} \\
\hline
\end{tabular}

ALT = Admission Laboratory Tests; APACHEII= Acute Physiology and Chronic Health Evaluation; ATS = Australasian Triage Scale; CriSTAL= Criteria for Screening and Triaging to

Appropriate aLternative care; CURB65=Confusion, Urea, Respiration, Blood pressure age > 65; EWS = Early Warning Score; GS = Goodacre Score; H1NI=Swine flu; HOTEL= Hypotension, 
Oxygen saturation, low Temperature, ECG changes and Loss of independence Score; IDSA/ATS $2007=$ Infectious Diseases Society of America/American Thoracic Society 2007 Pneumonia Guidelines; mBTS= modified British Thoracic Society rule; MPM=Mortality Probability Models; NIVO=Non-Invasive Ventilation Outcomes; N/R=Not reported; PELOD-2

= Pediatric Logistic Organ Dysfunction 2; ProVent14=Platelets, Requirement for vasopressor or dialysis after 14days of ventilation; REMS = Rapid Emergency Medicine Score; SAPS= Simplified Acute Physiology Score; SAPSII = Simplified Acute Physiology Score; SCS= Simple Clinical Score; SI= Shock Index; SMART-COP=Systolic BP, Multilobar involvement, Albumin, Respiration, Tachycardia, $\mathrm{O}_{2}$ saturation, $\mathrm{pH}$; SOFA = Sepsis-related Organ Failure Assessment; SMS-ICU= Simplified Mortality Score for ICU; STSS= Simple Triage Scoring System; TIMM = Triage Information Mortality Model; TTS = Track and Trigger System; WPS = Worthing Physiological Scoring System 
medRxiv preprint doi: https://doi.org/10.1101/2020.09.20.20198184; this version posted September 23, 2020. The copyright holder for this preprint (which was not certified by peer review) is the author/funder, who has granted medRxiv a license to display the preprint in

All rights reserved. No reuse allowed without permission.

Table2. Summary of consensus/taskforce/algorithm recommendations for rationing ICU care and ventilators during pandemics according to patient status and response to treatment

\section{Highest priority for ventilator and ICU access}

- Patients with initial SOFA $\leq 11$ who showed improvement (SOFA decreases) at 48 and 120-hour, and those with initial SOFA $<8$ with little ( $<3$ points decrease) or no improvement in the previous 72 hours [20]

- SOFA score $\leq 7$ or single organ failure [23,28]

- Other more stringent criteria were SOFA <6, age 12-40 years, and absence of life limiting conditions.[18]

- Hypoxaemia $\left(\mathrm{SpO}_{2}<90 \%\right)$ or impending respiratory failure [11,20] or $\mathrm{SpO}_{2}<92 \%$ with increased respiratory rate/exhaustion[26]

- Clinical evidence of shock (Systolic Blood Pressure < 90mmHg) [11,20]

\section{Intermediate priority for ICU or ventilator}

- Patients with SOFA score 6-9, age 41-60 and minor comorbidities with small impact on long-term survival. [18]

- Patients with SOFA <8 with no improvement from initial assessment.[20]

- Patient with SOFA 8-11 if no patient in the high priority category requires bed [23]

Exclusion/removal from ventilator treatment in the face of resource scarcity

- Patients who had experienced an unwitnessed cardiac arrest, have terminal cancer, or irreversible organ failure [17]

- SOFA >12 in patients with severe comorbidities and high risk of death within 1 year including age $\geq 75$ years. [18]

- AGILITIES score >100 integrating current clinical parameters, medical and surgical history, treatments and tests administered in the previous 6 hours, and using threats to healthcare providers as criterion to deny access [19]

- Patients near immediate death despite aggressive therapy, and those with unwitnessed cardiac arrest or cardiac arrest unresponsive to standard interventions [16]

\section{Exclusion from/discharge from ICU (too ill to benefit from ICU support)}

- SOFA score of $>11$ combined with comorbidities and not likely to benefit $[11,17,22]$

- A clear indication of $\geq 6$ organ failures with a SOFA of 15 , or severe chronic disease with short life expectancy (85+ years) [15]

- Unwitnessed cardiac arrest, metastatic cancer, end-stage organ failure [28]

- SOFA scores not improving after 48 hours in mechanically ventilated patients [24]

Table S2.1 in Supplement 2 lists specific details of some tools used for decision-making about ICU admission and ventilator allocation during pandemics along with their reported accuracy (AUROC, OR or sensitivity/specificity). Recommendations in patients who 
medRxiv preprint doi: https://doi.org/10.1101/2020.09.20.20198184; this version posted September 23, 2020. The copyright holder for this preprint (which was not certified by peer review) is the author/funder, who has granted medRxiv a license to display the preprint in

All rights reserved. No reuse allowed without permission.

warrant high priority access to ICU care but have a poor prognosis were ambiguous. The COVID-19 clinical risk score predicted either need for critical care, need for ventilator or the risk of in-hospital death for patients with COVID-19, based on age, abnormal chest radiography, haemoptysis, dyspnoea, unconsciousness and history of cancer [25]. Another triage tool also had composite outcomes for patients with a score of $\geq 3$ (including age, respiratory rate, oxygen saturation, shock index and altered mental status) [27]. The CATs tool was based on 5 respiratory criteria and evidence of shock and altered level of consciousness to predict the need for mechanical ventilation or ICU admission or the risk of death but did not indicate when to set a threshold for choosing a care pathway [26].

\section{Prognostic tools used in non-crisis situations}

Our study also explored whether triage algorithms/factors used for ICU, emergency departments or in hospital wards in non-crisis situations (Supplement 2, Table S2.2), could add value to the above pandemic recommendations. The majority of these prognostic indicators were derived from large patient population studies and predicted in-hospital or post-discharge mortality. Only four indicators were based on expert consensus, of which three $[29,49,51]$ used SOFA or qSOFA for predicting outcomes, while a ward-based rule to predict mortality used the CURB65 score [69]. The tools applied predominantly to adult patients in routine ICU care (18 studies) or patients being assessed in emergency departments (21 studies), with only a few (5 studies) used in routine ward care.

Unlike pandemic tools, which focus on acute organ failure, many routine care decisionmaking algorithms rely more on patient history of chronic illness [34,38,41,46,52,60,61,65,66,68], admission type (emergency, medical, elective surgery, non-trauma) [30,31,35,38,39,41,65], and age $[38,39,46,54,57,59,60,62,65,68,70,71]$.

\section{Triage algorithms, scores and tools used in non-crisis ICU care}

Instruments for decision-making about ICU triage this category also included SOFA, and qSOFA, but a diverse collection was a: Simplified Mortality Score for the ICU (SMS-ICU), ProVent 14 score, Simplified Acute Physiology Score (SAPSS II, SAPS III), SMART -COP 
medRxiv preprint doi: https://doi.org/10.1101/2020.09.20.20198184; this version posted September 23, 2020. The copyright holder for this preprint (which was not certified by peer review) is the author/funder, who has granted medRxiv a license to display the preprint in

All rights reserved. No reuse allowed without permission.

score, Mortality Probability Models (MPM), and Acute Physiology and Chronic Evaluation (APACHE II, III) and for children the Revised Paediatric Index of Mortality and PELOD-2.

ICU-based algorithms relied predominantly on laboratory variables or acute treatments such as those for sepsis or respiratory failure $[35,37,39,41-43,46]$ and two relied solely on a single biomarker cut-off: Secretoneurin [44] and Procalcitonin respectively [45]. Five of the 18 articles on routine care included algorithms to predict clinical deterioration with a need for ICU admission [36,37,40,46,49]. Only one article included a tool to predict the need for vasopressor treatment and respiratory support [37]. Two articles provided information on patients who are unlikely to benefit from (ongoing) ICU treatment $[39,46]$.

\section{Emergency Department algorithms used in non-crisis situations}

Emergency department decision-making algorithms combined laboratory tests and clinical history or examination: Severe community acquired pneumonia score (SCAP), Infectious Diseases Society of America/American Thoracic Society IDSA/ATS), the Shock Index (SI), Mortality in Emergency Department Sepsis (MEDS) score, Simple Clinical Score (SCS), Emergency Severity Index (ESI), Triage Information Mortality model (TIMM), and Criteria for screening and triaging to appropriate alternative care (CriSTAL). Two studies predicted in-patient mortality based only on frailty syndrome [52,68], and six studies based mortality predictions purely on laboratory test results $[48,50,63,64,66,67]$.

Six of the 21 studies among patients in the emergency department predicted the need for potential transfer to ICU based on clinical and laboratory variables $[54,56,58,61,62,66]$. The other studies predicted mortality at different time points. One study focused on decisionmaking about ICU admission in patients on chronic dialysis [67]. Two studies provided recommended a score cut-off for referral to palliative care [61,65].

\section{Ward-based triage used in non-crisis situations}

Five scoring systems predicted in-hospital and 30-day mortality among ward-based patients (Simple Clinical Score, HOTEL, CURB65, NIVO, and Mortality Predictive Model for Children (MPMC) based on a combination of clinical criteria and laboratory test results 
medRxiv preprint doi: https://doi.org/10.1101/2020.09.20.20198184; this version posted September 23, 2020. The copyright holder for this preprint (which was not certified by peer review) is the author/funder, who has granted medRxiv a license to display the preprint in All rights reserved. No reuse allowed without permission.

[47,69-72]. One scoring system predicted the need for non-invasive ventilation in ward-based patients with COPD and was recommended for setting a ceiling of treatment [47].

Summary of variables and prognostic factors used for decision-making in non-pandemic situations

Table S2.2 in Supplement 2 gives an overview of variables predicting poor patient outcome for decision-making about ICU admission (IDSA/ATS, ESI) or discharge in non-pandemic situations presented for ICU, ED and ward care. Several tools including SAPS II, APACHE II/III, SOFA) predicted in-hospital mortality risk. Results from the validation of Simple Clinical Score, CriSTAL tool, and Shock index, indicated a good predictive value to identify people who will require ICU admission, palliative care or will die in the short term postdischarge.

Using combined variables and prognostic factors for decision-making in pandemic situations

A simplified example of triage recommendations for pandemic times based on predicted prognosis is illustrated in Figure 2. The parameters and accompanying cut-off points are extracted from the comprehensive factors used in both pandemic and routine care shown in Supplement 2. Elements from this catalogue of triage criteria could be used to design locally relevant triage tools.

In this priority setting scenario for pandemics, two types of patients are unambiguously outside eligibility thresholds and therefore excluded from access to critical care resources: patients in group 1 who are 'too healthy' and patients in group 5 who are 'too sick' (Figure 2). For other severity profiles (patients in groups 2 to 5 with increasingly poorer prognosis) some parameters may be unknown at triage; a suite of alternatives are listed to assist with decisionmaking. Periodic reassessment at 48, 96 and 120 hours is recommended $[11,20,24,28,38]$ to determine the need to discharge to ward due to improvement, escalate treatment to ICU, or withdraw ICU treatment and refer for palliative care as indicated by the arrows between all groups. 
medRxiv preprint doi: https://doi.org/10.1101/2020.09.20.20198184; this version posted September 23, 2020. The copyright holder for this preprint (which was not certified by peer review) is the author/funder, who has granted medRxiv a license to display the preprint in

All rights reserved. No reuse allowed without permission.

\section{<Figure 2. Sample prioritisation criteria to determine access or exclusion from critical care services during pandemics using combinations of crisis and non-crisis algorithms> about here}

The concept of a waiting list may not apply under normal circumstances, but in overwhelmed health systems, people with characteristics in group 4 may have to be managed on the ward until an ICU bed becomes available and no patient with a higher priority profile is competing for an ICU bed.

Patients who are deemed to be beyond salvageable -group 5 with the poorest prognosisusually have already experienced a catastrophic event like a cardiac arrest and/or are unconscious and/or are refractory to vasopressors and/or need or have been on mechanical ventilation for 14+ days and/or have documented advanced chronic illness/frailty/age. The general recommendation is not to use scarce resources on these patients during a public health crisis. Importantly, no decision should be based on single parameters or undesirable individual characteristics.

\section{Ethical and resource considerations in crisis decision-making}

A number of publications identified in this scoping review explored social, ethical, and political considerations when making decisions about patients' access to ICU and ventilator treatment (Table 3). Key principles included institutional and public transparency about the decision-making process, consultation with interdisciplinary groups, and establishing local partnerships for implementation of decision-making processes in a local context. Studies varied in their approach to including patients' illness severity scores in the decision-making process, with some supporting their inclusion due to objectivity and validity for patient groups [11,18], and others recommending against their use in isolation to predict individual patient outcomes [80].

Guidelines warned against making judgments about the worth of individuals, and unintentionally discriminating population subgroups such as the elderly or obese, or people with certain conditions as well as specific ethnic groups or people in non-health occupations. However, some publications outlined that older age is associated with a higher risk of death 
medRxiv preprint doi: https://doi.org/10.1101/2020.09.20.20198184; this version posted September 23, 2020. The copyright holder for this preprint (which was not certified by peer review) is the author/funder, who has granted medRxiv a license to display the preprint in All rights reserved. No reuse allowed without permission.

$[19,21,25]$ or flagged a natural shorter life expectancy as an additional reason for excluding patients from critical care [15], and indicated that among young people most years of life could potentially be saved [18]. Giving preferential treatment to population subgroups such as those with dependent children [81], caregivers of elderly [81] or frontline pandemic health workers [17] were discouraged by some and promoted by others [80,85]. Likewise, discrepancies were found about the recommendation to (not) involve treating clinicians in the decision-making process, with some studies supporting the exclusion of the treating clinicians $[15,86]$ while others recommended that the senior treating clinician should lead the decision-making process [80]. 


\title{
Table 3. Ethical, legal, practical and clinical considerations when allocating ICU care ventilator treatment
}

\author{
What to conside \\ - Make triage policy and rationing criteria transparent to staff and the public to ensure understanding of the \\ reasons for access restrictions [2,15,79,80] \\ - Establish local/regional partnerships to effectively manage resource shortages and triage pathways \\ $[2,15,75,80]$ \\ - When resources cannot be maintained, unequal treatment may be justified and choice determined on the \\ basis of medical need and likely benefit[12] by using a proportionately lower amount of resources [81] \\ - People making decisions about resource allocation should not be the treating clinicians but preferably a \\ central triage committee of senior clinicians and legal officers $[15,79,86]$ \\ - First come first served or lottery/ random assignment if two patients with same level of risk present at the \\ same time [81] \\ - Decision-makers should not be aware of patients' identity [19] \\ - Revise existing laws and develop liability protection for clinicians using scoring systems for decision- \\ making about allocation of scarce resources [15,29] \\ - Priority to be given to those who have had less opportunity to live their lives $[2,29]$ \\ - Align patients values and preferences with decisions to admit or remain in ICU [87] \\ - Build capacity for alternatives to ICU care before life-sustaining resources become limited and provide \\ alternative options such as high quality palliative care [15] \\ - Ongoing update of the triage process as new evidence of disaster experiences, research, planning, and \\ modelling becomes available [15]
}

\section{Clinical decisions}

- Educate lay people to better understand goals of care so they can be partners in a shared decision-making process $[74,88]$

- Use best available objective parameters to determine patients' risk profile [15], and allocate patients to waiting lists or immediate resource access [15]

- Triage patients to higher level of care if they have the greatest medical need and higher chances of survival $[20,81]$

- Re-assess response to ventilator treatment and other therapies periodically, to see if patients are recovering or if they are deteriorating to confirm that the eligibility criteria are still met (i.e. risk of death, lack of improvement of SOFA after 48 hours) $[19,24,81]$

- If the patient does not deteriorate, commit the ventilator for 10-12 days[3]. For patients on mechanical ventilation for 14+ days, clinicians should have a discussion with the family about the poor prognosis and goals of care [39]

- Refer to palliative care from ED if risk of death is very high (i.e. prior CPR or cardiac arrest) $[16,17,29]$

- Discharge patients from ICU who have an increased mortality risk or are unlikely to benefit from ICU treatment $[15,17,22,24]$

- Apply objective criteria, set ceilings of treatment, discuss with families a referral to palliative care, and remove those from ventilator treatment who no longer meet objective criteria for benefit $[10,18,19]$

\section{What to avoid when deciding on ICU/ventilator allocation}

- Considering older age as single criterion for exclusion from higher level of care [17,29,36,65]

- Basing decisions on gender, race, gender, sexual orientation, religion, disability, social status, personal connections, wealth, citizenship, insurance status $[19,80]$

- Using obesity to inform prognosis in isolation from other risk factors [18]

- Prioritising healthcare workers [17],people with dependent parents or children [81]

- Allocating a ventilator to a pregnant woman to save a non-viable foetus ( $<24$ weeks gestation) although appropriate to save the woman [19]

- Triaging people with a single condition to ICU ahead of those with comorbidities [17]

- Using the number of medical conditions rather than their severity to make decisions [38]

- Using Shock Index in isolation to rule out triage to ICU [56]

- Offering short trials of ICU to patients who are not eligible (low illness severity, minor comorbidities, young age) $[18,80]$

- Offering ICU beds to patients whose authentic values or informed treatment preferences are not consistent with ICU treatment/admission $[13,74]$ 
medRxiv preprint doi: https://doi.org/10.1101/2020.09.20.20198184; this version posted September 23, 2020. The copyright holder for this preprint (which was not certified by peer review) is the author/funder, who has granted medRxiv a license to display the preprint in All rights reserved. No reuse allowed without permission.

\section{Discussion}

This scoping review identified key principles of decision-making about allocation of intensive care beds and ventilator treatment during pandemics including the need for a local expert committee of decision-makers, use of best available objective clinical criteria, careful steering from unintentional discrimination of vulnerable groups, consistent application of rules, transparency, and ethical justification of service limitations. Our review identified a range of tools to support the decision-making process and outlined their characteristics (62 publications on guidelines, frameworks, algorithms, laboratory parameters and predictive tools).

In addition, we systematically collated scores and algorithms that can be used for triage decision-making in routine care (in non-pandemic situations) in the emergency department, on the wards, or in the ICU. Some of the identified tools were derived from influenza pandemics and non-respiratory disease public health emergencies, yet they can be extrapolated to other public health emergencies including COVID-19.

\section{How do the results fit in with previous research and policies?}

It is generally accepted that triage protocols should only be activated when resource scarcity is imminent [21,46]; be locally relevant through a committee of expert decision-makers; make best use of relevant objective criteria; be carefully steered from unintentionally discriminating vulnerable groups; consistently apply agreed rules; and be publicly transparent and ethically justifiable. ICU admission criteria vary from country to country [89] and can change overtime as technology advances, but generally rely on expert assessment of the patient's illness severity, the health system culture, resources, patient preference, and ethical considerations. Admission is considered appropriate from the medical perspective, for those who are likely to require mechanical ventilation, or support for single or multiple organ failure [89]. However, when resources are overwhelmed by a surge in number of cases requiring escalation of care, these criteria need to vary towards "crisis standards of care"[90]. 
medRxiv preprint doi: https://doi.org/10.1101/2020.09.20.20198184; this version posted September 23, 2020. The copyright holder for this preprint (which was not certified by peer review) is the author/funder, who has granted medRxiv a license to display the preprint in

All rights reserved. No reuse allowed without permission.

It has been suggested that vital signs in critically ill patients can inform triage decisions during pandemics [27]. Quick and simplified scores e.g. qSOFA vs. SOFA) have been developed to predict sepsis mortality. However, there might be trade-offs between the simplicity of a score and its sensitivity and specificity. Using such scoring systems to deny access to care is controversial. [91]Complex algorithms with multiple variables increase the burden of data collection without necessarily increasing the predictive ability (e.g. APACHE), but some scores with multiple variables have been shown to increase predictive ability (SIRS and NEWS). The appeal of some relatively simple predictive tools (mSOFA, qSOFA, SCS, CriSTAL, AGILITIES) is that they do not require additional testing, although some clinicians warn against the use of population-based algorithms in isolation to guide decisions for individuals [80].

\section{No consensus on ethical and social considerations}

We found mixed support for some of the subjective criteria in the expert consensus and triage publications. Fears of discrimination of elderly, functionally impaired, cognitively impaired, obese or immunosuppressed patients when allocating resources have been publicly expressed [18]. Under the "life cycle principle" younger patients receive priority because they have had the least opportunity to live through stages of life [18]. A different ethical principle to make allocation decisions is the "maximizing life-years" which takes into account a patient's life expectancy based on age, co-morbidities and other factors (hence prioritising the young) [29]. The principle behind giving healthcare workers priority [85] is a 'multiplier effect'. When healthcare workers recover they can contribute to saving the lives of many others. Although this principle may have some ethical validity, it did not receive much support in the consensus statements.

\section{Implementation strategies to manage clinician burden and public dissatisfaction}

In overwhelmed health systems, many people with poorer prognosis may be diverted to palliative care, thus increasing demand for accelerated staff training in the communication with patients and families about end-of-life care [92]. Some publications suggested involvement of an external expert committee of senior clinicians to make decisions about ceilings of care in order to reduce the burden on the treating clinicians [15,19,86]. A legal 
medRxiv preprint doi: https://doi.org/10.1101/2020.09.20.20198184; this version posted September 23, 2020. The copyright holder for this preprint (which was not certified by peer review) is the author/funder, who has granted medRxiv a license to display the preprint in

All rights reserved. No reuse allowed without permission.

framework needs to be in place to protect healthcare workers from litigation if they allocate limited resources in accordance with ethical guidelines [15,93,94].

Triage aims to maximise positive health outcomes for the largest possible number of patients. Triage protocols can have negative consequences for patients who are already hospitalised or treated in ICU for conditions not related to a pandemic (e.g. stroke or myocardial infarction) who would not have been denied access under normal conditions [23]. Those admitted to ICU, should be reassessed at 48 and up to 120 hours to determine ongoing eligibility for ICU resources [21,24] or to discharge them to palliative care. While an early, gradual and personalised approach to prognostic disclosure in routine practice is recommended in terminal illness [95], this may not be possible in mass emergencies. Early prognostic disclosure may be necessary during pandemics and other public health emergencies, and "advance care planning" will have to be expedited at the time of admission. Patient and family involvement in treatment decisions may be limited by hospital policies concerned with service capacity and healthcare worker safety. However, when possible, recognising triggers for early palliative care referral and/or treatment withdrawal [96] and adhering to patient preferences [97] should be integral to management policies.

It has been recommended to invite input from members of at-risk groups or their caregivers into algorithms to determine access to ICU and ventilators during pandemics [18,93,98]. However, this may not work in all cultures, and time pressure will likely be prohibitive of consultation with all stake holders. Unfortunately, efficient allocation of ventilators may unintentionally further increase social inequalities [99]. Supplementary strategies to build trust during a pandemic include public transparency on the objective decision-making framework $[18,98]$ and disseminating information about decision-making frameworks to the public.

\section{Strengths and limitations of this review}

We believe that this scoping review provides a useful resource for decision-making about ICU and ventilator allocation during pandemics. This is a discussion starter and can inform objective guidelines beyond the guiding principles of preparedness, organisational management for resource allocation, expanded scope of practice, equity and social justice currently published [3,79,100-103]. Prognostic indicators and other decision tools presented have been based on a multitude on criteria, which can be combined to create locally-relevant 
medRxiv preprint doi: https://doi.org/10.1101/2020.09.20.20198184; this version posted September 23, 2020. The copyright holder for this preprint (which was not certified by peer review) is the author/funder, who has granted medRxiv a license to display the preprint in All rights reserved. No reuse allowed without permission.

triage algorithms. This is a discussion starter and can inform objective guidelines beyond the guiding principles of equity and social justice currently published.

We did not conduct risk of bias assessment of included studies as the purpose of this scoping review was to collate a wide range of risk prediction and decision tools, which will have to be adapted to local settings. We excluded some validation studies from low-income countries [104] which showed good predictive ability of the combined variables as there was the chance of lesser generalisability of their patient population to health systems in industrialised nations -the focus of our study.

\section{Conclusions}

The catalogue of resources we assembled provides guidance on variables used to prioritise patients for critical care in the face of scarce life-sustaining resources. Patients' clinical or demographic characteristics alone and rigid triage systems are not the preferred way of allocating resources in a constrained healthcare system. The patient perspective needs to be taken into account. Discrimination against certain population groups must be avoided at every level of disease severity. A combination of variables used in prognostic scores (based on chronic and acute risk factors) and other decision tools presented here can be combined to create locally-relevant triage algorithms to assist decisions about ICU admission and discharge and/or access to ventilator treatments during a pandemic. This unique resource will help service managers and clinicians with the emotional and ethical burden of having to select some patients over others for life-sustaining treatments. More importantly objective guidelines will provide transparency about rationing resources to the patients and communities they serve.

\section{Competing interests}

The authors declare that they have no competing interests

\section{Funding}

No funding was available for this work. 


\section{References}

1. Tanne JH; Hayasaki E; Zastrow M; Pulla P; Smith P; Garcia RA. Covid-19: how doctors and healthcare systems are tackling coronavirus worldwide. BMJ 2020, 368, m1090.

2. Maves, R.C.; Downar, J.; Dichter, J.R.; Hick, J.L.; Devereaux, A.; Geiling, J.A.; Kissoon, N.; Hupert, N.; Niven, A.S.; King, M.A., et al. Triage of Scarce Critical Care Resources in COVID-19 An Implementation Guide for Regional Allocation: An Expert Panel Report of the Task Force for Mass Critical Care and the American College of Chest Physicians. Chest 2020, 158, 212225, doi:10.1016/j.chest.2020.03.063.

3. Aziz, S.; Arabi, Y.M.; Alhazzani, W.; Evans, L.; Citerio, G.; Fischkoff, K.; Salluh, J.; Meyfroidt, G.; Alshamsi, F.; Oczkowski, S., et al. Managing ICU surge during the COVID-19 crisis: rapid guidelines. Intensive Care Med 2020, 10.1007/s00134-020-06092-5, 1-23, doi:10.1007/s00134-020-06092-5.

4. Immovilli, P.; Morelli, N.; Antonucci, E.; Radaelli, G.; Barbera, M.; Guidetti, D. COVID-19 mortality and ICU admission: the Italian experience. Crit Care 2020, 24, 228-228, doi:10.1186/s13054-020-02957-9.

5. Mahase, E. Covid-19: most patients require mechanical ventilation in first 24 hours of critical care. BMJ 2020, 368, m1201, doi:10.1136/bmj.m1201.

6. Auld, S.; Caridi-Scheible, M.; Blum, J.M.; Robichaux, C.J.; Kraft, C.S.; Jacob, J.T.; Jabaley, C.S.; Carpenter, D.; Kaplow, R.; Hernandez, A.C., et al. ICU and ventilator mortality among critically ill adults with COVID-19. Crit Care Med 2020, Online First, doi:10.1097/CCM.0000000000004457.

7. Grasselli, G.; Zangrillo, A.; Zanella, A.; Antonelli, M.; Cabrini, L.; Castelli, A.; Cereda, D.; Coluccello, A.; Foti, G.; Fumagalli, R., et al. Baseline Characteristics and Outcomes of 1591 Patients Infected With SARS-CoV-2 Admitted to ICUs of the Lombardy Region, Italy. Jama 2020, 323, 1574-1581, doi:10.1001/jama.2020.5394.

8. Cummings, M.J.; Baldwin, M.R.; Abrams, D.; Jacobson, S.D.; Meyer, B.J.; Balough, E.M.; Aaron, J.G.; Claassen, J.; Rabbani, L.E.; Hastie, J., et al. Epidemiology, clinical course, and outcomes of critically ill adults with COVID-19 in New York City: a prospective cohort study. Lancet (London, England) 2020, 395, 1763-1770, doi:10.1016/S0140-6736(20)31189-2.

9. Ioannidis, J.P.A.; Axfors, C.; Contopoulos-Ioannidis, D.G. Population-level COVID-19 mortality risk for non-elderly individuals overall and for non-elderly individuals without underlying diseases in pandemic epicenters. medRxiv 2020, 10.1101/2020.04.05.20054361, 2020.2004.2005.20054361, doi:10.1101/2020.04.05.20054361.

10. Toltzis, P.; Soto-Campos, G.; Shelton, C.; Kuhn, E.M.; Hahn, R.; Kanter, R.K.; Wetzel, R.C. Evidence-Based Pediatric Outcome Predictors to Guide the Allocation of Critical Care Resources in a Mass Casualty Event. Pediatric critical care medicine : a journal of the Society of Critical Care Medicine and the World Federation of Pediatric Intensive and Critical Care Societies 2015, 16, e207-216, doi:10.1097/pcc.0000000000000481.

11. Christian, M.D.; Hawryluck, L.; Wax, R.S.; Cook, T.; Lazar, N.M.; Herridge, M.S.; Muller, M.P.; Gowans, D.R.; Fortier, W.; Burkle, F.M. Development of a triage protocol for critical care during an influenza pandemic. Cmaj 2006, 175, 1377-1381.

12. Antommaria, A.H.; Sweney, J.; Poss, W.B. Critical appraisal of: triaging pediatric critical care resources during a pandemic: ethical and medical considerations. Pediatric critical care medicine : a journal of the Society of Critical Care Medicine and the World Federation of Pediatric Intensive and Critical Care Societies 2010, 11, 396-400, doi:10.1097/PCC.0b013e3181dac698.

13. Cardona M; Anstey M; Lewis ET; Shanmugam S; Hillman K. Appropriateness of intensive care treatments near the end of life during the COVID-19 pandemic. Breathe 2020, Sept, In Press, doi:https://doi.org/10.1183/20734735.0062-2020. 
medRxiv preprint doi: https://doi.org/10.1101/2020.09.20.20198184; this version posted September 23, 2020. The copyright holder for this preprint (which was not certified by peer review) is the author/funder, who has granted medRxiv a license to display the preprint in perpetuity.

All rights reserved. No reuse allowed without permission.

14. LeDuc, J.W.; Barry, M.A. SARS, the First Pandemic of the 21st Century. Emerg Infect Dis 2004, 10, e26-e26, doi:10.3201/eid1011.040797_02.

15. Devereaux, A.V.; Dichter, J.R.; Christian, M.D.; Dubler, N.N.; Sandrock, C.E.; Hick, J.L.; Powell, T.; Geiling, J.A.; Amundson, D.E.; Baudendistel, T.E., et al. Definitive care for the critically ill during a disaster: a framework for allocation of scarce resources in mass critical care: from a Task Force for Mass Critical Care summit meeting, January 26-27, 2007, Chicago, IL. Chest 2008, 133, 51s-66s, doi:10.1378/chest.07-2693.

16. New York State Task Force in Life and The Law. Ventilator allocation guidelines; 2015.

17. Powell, T.; Christ, K.C.; Birkhead, G.S. Allocation of ventilators in a public health disaster. Disaster med 2008, 2, 20-26, doi:https://dx.doi.org/10.1097/DMP.0b013e3181620794.

18. White, D.B.; Katz, M.H.; Luce, J.M.; Lo, B. Who should receive life support during a public health emergency? Using ethical principles to improve allocation decisions. Ann Intern Med 2009, 150, 132-138, doi:10.7326/0003-4819-150-2-200901200-00011.

19. Wilkens, E.P.; Klein, G.M. Mechanical ventilation in disaster situations: a new paradigm using the AGILITIES Score System. Am J Disaster Med 2010, 5, 369-384.

20. Chuang, E.; Cuartas, P.A.; Powell, T.; Gong, M.N. “We're Not Ready, But I Don't Think You're Ever Ready." Clinician Perspectives on Implementation of Crisis Standards of Care. AJOB Empirical Bioethics 2020, 11, 148-159, doi:10.1080/23294515.2020.1759731.

21. Adeniji, K.A.; Cusack, R. The Simple Triage Scoring System (STSS) successfully predicts mortality and critical care resource utilization in $\mathrm{H} 1 \mathrm{~N} 1$ pandemic flu: a retrospective analysis. Crit Care 2011, 15, R39, doi:10.1186/cc10001.

22. Grissom, C.K.; Brown, S.M.; Kuttler, K.G.; Boltax, J.P.; Jones, J.; Jephson, A.R.; Orme, J.F., Jr. A modified sequential organ failure assessment score for critical care triage. Disaster Med Public Health Prep 2010, 4, 277-284, doi:10.1001/dmp.2010.40.

23. Guest, T.; Tantam, G.; Donlin, N.; Tantam, K.; McMillan, H.; Tillyard, A. An observational cohort study of triage for critical care provision during pandemic influenza: 'clipboard physicians' or 'evidenced based medicine'? Anaesthesia 2009, 64, 1199-1206, doi:10.1111/j.1365-2044.2009.06084.x.

24. Khan, Z.; Hulme, J.; Sherwood, N. An assessment of the validity of SOFA score based triage in H1N1 critically ill patients during an influenza pandemic. Anaesthesia 2009, 64, 1283-1288, doi:10.1111/j.1365-2044.2009.06135.x.

25. Liang, W.; Liang, H.; Ou, L.; Chen, B.; Chen, A.; Li, C.; Li, Y.; Guan, W.; Sang, L.; Lu, J., et al. Development and Validation of a Clinical Risk Score to Predict the Occurrence of Critical IIIness in Hospitalized Patients With COVID-19. JAMA Intern Med 2020, 180, 1-9, doi:10.1001/jamainternmed.2020.2033.

26. Semple, M.G.; Myles, P.R.; Nicholson, K.G.; Lim, W.S.; Read, R.C.; Taylor, B.L.; Brett, S.J.; Openshaw, P.J.; Enstone, J.E.; McMenamin, J., et al. An evaluation of community assessment tools (CATs) in predicting use of clinical interventions and severe outcomes during the A(H1N1)pdm09 pandemic. PloS one 2013, 8, e75384, doi:10.1371/journal.pone.0075384.

27. Talmor, D.; Jones, A.E.; Rubinson, L.; Howell, M.D.; Shapiro, N.I. Simple triage scoring system predicting death and the need for critical care resources for use during epidemics. Crit Care Med 2007, 35, 1251-1256, doi:10.1097/01.Ccm.0000262385.95721.Cc.

28. Kim, K.M.; Cinti, S.; Gay, S.; Goold, S.; Barnosky, A.; Lozon, M. Triage of mechanical ventilation for pediatric patients during a pandemic. Disaster med 2012, 6, 131-137, doi:https://dx.doi.org/10.1001/dmp.2012.19.

29. Daugherty-Biddison, E.L.; Faden, R.; Gwon, H.S.; Mareiniss, D.P.; Regenberg, A.C.; SchochSpana, M.; Schwartz, J.; Toner, E.S. Too Many Patients...A Framework to Guide Statewide Allocation of Scarce Mechanical Ventilation During Disasters. Chest 2019, 155, 848-854, doi:https://dx.doi.org/10.1016/j.chest.2018.09.025.

30. Dólera-Moreno, C.; Palazón-Bru, A.; Colomina-Climent, F.; Gil-Guillén, V.F. Construction and internal validation of a new mortality risk score for patients admitted to the intensive care unit. Int J Clin Pract 2016, 70, 916-922, doi:10.1111/ijcp.12851. 
31. Granholm, A.; Perner, A.; Krag, M.; Hjortrup, P.B.; Haase, N.; Holst, L.B.; Marker, S.; Collet, M.O.; Jensen, A.K.G.; Møller, M.H. Development and internal validation of the Simplified Mortality Score for the Intensive Care Unit (SMS-ICU). Acta Anaesthesiol Scand 2018, 62, 336-346, doi:10.1111/aas.13048.

32. Gupta, P.; Rettiganti, M.; Gossett, J.M.; Daufeldt, J.; Rice, T.B.; Wetzel, R.C. Development and Validation of an Empiric Tool to Predict Favorable Neurologic Outcomes Among PICU Patients. Crit Care Med 2018, 46, 108-115, doi:10.1097/ccm.0000000000002753.

33. Hajjar, L.A.; Nakamura, R.E.; de Almeida, J.P.; Fukushima, J.T.; Hoff, P.M.; Vincent, J.L.; Auler, J.O., Jr.; Galas, F.R. Lactate and base deficit are predictors of mortality in critically ill patients with cancer. Clinics (Sao Paulo) 2011, 66, 2037-2042, doi:10.1590/s180759322011001200007.

34. Slater, A.; Shann, F.; Pearson, G. PIM2: a revised version of the Paediatric Index of Mortality. Intensive Care Med 2003, 29, 278-285, doi:10.1007/s00134-002-1601-2.

35. Aegerter, P.; Boumendil, A.; Retbi, A.; Minvielle, E.; Dervaux, B.; Guidet, B. SAPS II revisited. Intensive Care Med 2005, 31, 416-423, doi:10.1007/s00134-005-2557-9.

36. Brunner-Ziegler, S.; Heinze, G.; Ryffel, M.; Kompatscher, M.; Slany, J.; Valentin, A. "Oldest old" patients in intensive care: prognosis and therapeutic activity. Wien Klin Wochenschr 2007, 119, 14-19, doi:10.1007/s00508-007-0771-x.

37. Charles, P.G.; Wolfe, R.; Whitby, M.; Fine, M.J.; Fuller, A.J.; Stirling, R.; Wright, A.A.; Ramirez, J.A.; Christiansen, K.J.; Waterer, G.W., et al. SMART-COP: a tool for predicting the need for intensive respiratory or vasopressor support in community-acquired pneumonia. Clinical infectious diseases : an official publication of the Infectious Diseases Society of America 2008, 47, 375-384, doi:10.1086/589754.

38. Higgins, T.L.; Teres, D.; Nathanson, B. Outcome prediction in critical care: the Mortality Probability Models. Curr Opin Crit Care 2008, 14, 498-505, doi:10.1097/MCC.0b013e3283101643.

39. Hough, C.L.; Caldwell, E.S.; Cox, C.E.; Douglas, I.S.; Kahn, J.M.; White, D.B.; Seeley, E.J.; Bangdiwala, S.I.; Rubenfeld, G.D.; Angus, D.C., et al. Development and Validation of a Mortality Prediction Model for Patients Receiving 14 Days of Mechanical Ventilation. Crit Care Med 2015, 43, 2339-2345, doi:10.1097/ccm.0000000000001205.

40. Na, H.J.; Jeong, E.S.; Kim, I.; Kim, W.Y.; Lee, K. Clinical Application of the Quick Sepsis-Related Organ Failure Assessment Score at Intensive Care Unit Admission in Patients with Bacteremia: A Single-Center Experience of Korea. Korean J Crit Care Med 2017, 32, 247-255, doi:10.4266/kjccm.2017.00241.

41. Nielsen, A.B.; Thorsen-Meyer, H.C.; Belling, K.; Nielsen, A.P.; Thomas, C.E.; Chmura, P.J.; Lademann, M.; Moseley, P.L.; Heimann, M.; Dybdahl, L., et al. Survival prediction in intensive-care units based on aggregation of long-term disease history and acute physiology: a retrospective study of the Danish National Patient Registry and electronic patient records. The Lancet Digital Health 2019, 1, e78-e89, doi:10.1016/S2589-7500(19)30024-X.

42. Pannu, S.R.; Moreno Franco, P.; Li, G.; Malinchoc, M.; Wilson, G.; Gajic, O. Development and validation of severe hypoxemia associated risk prediction model in 1,000 mechanically ventilated patients*. Crit Care Med 2015, 43, 308-317, doi:10.1097/ccm.0000000000000671.

43. Godfrey, G.; Pilcher, D.; Hilton, A.; Bailey, M.; Hodgson, C.L.; Bellomo, R. Treatment limitations at admission to intensive care units in Australia and New Zealand: prevalence, outcomes, and resource use*. Crit Care Med 2012, 40, 2082-2089, doi:10.1097/CCM.0b013e31824ea045.

44. Rosjo, H.; Stridsberg, M.; Ottesen, A.H.; Christensen, G.; Petilla, V.; Linko, R.; Karlsson, S.; Varpula, T.; Ruokonen, E.; Omland, T. The novel cardiovascular biomarker secretoneurin predicts mortality and shock in critical ill patients with infections. European Heart Journal 2015, 36, 1053, doi:10.1093/eurheartj/ehv401. 
45. Schuetz, P.; Maurer, P.; Punjabi, V.; Desai, A.; Amin, D.N.; Gluck, E. Procalcitonin decrease over 72 hours in US critical care units predicts fatal outcome in sepsis patients. Crit Care 2013, 17, R115, doi:10.1186/cc12787.

46. Sprung, C.L.; Baras, M.; lapichino, G.; Kesecioglu, J.; Lippert, A.; Hargreaves, C.; Pezzi, A.; Pirracchio, R.; Edbrooke, D.L.; Pesenti, A., et al. The Eldicus prospective, observational study of triage decision making in European intensive care units: part l--European Intensive Care Admission Triage Scores. Crit Care Med 2012, 40, 125-131, doi:10.1097/CCM.0b013e31822e5692.

47. Hartley, T.M.; Lane, N.D.; Steer, J.; Elliott, M.W.; Sovani, M.; Curtis, H.J.; Fuller, E.R.; Murphy, P.B.; Hart, N.; Shrikrishna, D., et al. Predicting outcome from exacerbations of COPD requiring assisted ventilation: Results from the NIV outcome (NIVO) study. Thorax 2019, 74, A38-A39, doi:10.1136/thorax-2019-BTSabstracts2019.63.

48. Kristensen, M.; Iversen, A.K.S.; Gerds, T.A.; Østervig, R.; Linnet, J.D.; Barfod, C.; Lange, K.H.W.; Sölétormos, G.; Forberg, J.L.; Eugen-Olsen, J., et al. Routine blood tests are associated with short term mortality and can improve emergency department triage: a cohort study of $>12,000$ patients. Scand J Trauma Resusc Emerg Med 2017, 25, 115, doi:10.1186/s13049-017-0458-x.

49. Mark, K.; George, N.; Rasheed, H.; Meurer, D.; Allen, B.; Elie-Turenne, M.C.; Hou, P.; Seethala, R. QSOFA criteria predicts clinical outcomes of hospitalized emergency department pneumonia patients. Crit Care Med 2016, 44, 407, doi:10.1097/01.ccm.0000510001.55136.6c.

50. O'Sullivan, E.; Callely, E.; O'Riordan, D.; Bennett, K.; Silke, B. Predicting outcomes in emergency medical admissions - role of laboratory data and co-morbidity. Acute Med 2012, $11,59-65$.

51. Singer, M.; Deutschman, C.S.; Seymour, C.W.; Shankar-Hari, M.; Annane, D.; Bauer, M.; Bellomo, R.; Bernard, G.R.; Chiche, J.D.; Coopersmith, C.M., et al. The Third International Consensus Definitions for Sepsis and Septic Shock (Sepsis-3). Jama 2016, 315, 801-810, doi:10.1001/jama.2016.0287.

52. Soong, J.T.Y.; Poots, A.; Rolph, G.; Bell, D. Frailty syndromes coded within secondary user service(SUS) data predict inpatient mortality and long length of stay. Acute Medicine 2017, 16, 131-132.

53. Brabrand, M.; Folkestad, L.; Clausen, N.G.; Knudsen, T.; Hallas, J. Risk scoring systems for adults admitted to the emergency department: a systematic review. Scand J Trauma Resusc Emerg Med 2010, 18, 8, doi:10.1186/1757-7241-18-8.

54. España, P.P.; Capelastegui, A.; Gorordo, I.; Esteban, C.; Oribe, M.; Ortega, M.; Bilbao, A.; Quintana, J.M. Development and validation of a clinical prediction rule for severe community-acquired pneumonia. American journal of respiratory and critical care medicine 2006, 174, 1249-1256, doi:10.1164/rccm.200602-1770C.

55. Jalbout, N.A.; Hamade, B.; Balhara, K.S.; Hsieh, Y.H.; Bayram, J.D. Shock index as a predictor of hospital admission and inpatient mortality in a united states national database of emergency departments. Journal of Emergency Medicine 2017, 53, 433, doi:10.1016/j.jemermed.2017.08.040.

56. Koch, E.; Lovett, S.; Nghiem, T.; Riggs, R.A.; Rech, M.A. Shock index in the emergency department: utility and limitations. Open access emergency medicine : OAEM 2019, 11, 179199, doi:10.2147/oaem.S178358.

57. Teubner, D.J.; Considine, J.; Hakendorf, P.; Kim, S.; Bersten, A.D. Model to predict inpatient mortality from information gathered at presentation to an emergency department: The Triage Information Mortality Model (TIMM). Emerg Med Australas 2015, 27, 300-306, doi:10.1111/1742-6723.12425.

58. Brown, S.M.; Jones, J.P.; Aronsky, D.; Jones, B.E.; Lanspa, M.J.; Dean, N.C. Relationships among initial hospital triage, disease progression and mortality in community-acquired pneumonia. Respirology 2012, 17, 1207-1213, doi:10.1111/j.1440-1843.2012.02225.x. 
59. Grossmann, F.F.; Zumbrunn, T.; Frauchiger, A.; Delport, K.; Bingisser, R.; Nickel, C.H. At risk of undertriage? Testing the performance and accuracy of the emergency severity index in older emergency department patients. Ann Emerg Med 2012, 60, 317-325.e313, doi:10.1016/j.annemergmed.2011.12.013.

60. Kellett, J.; Deane, B. The Simple Clinical Score predicts mortality for 30 days after admission to an acute medical unit. Qjm 2006, 99, 771-781, doi:10.1093/qjmed/hcl112.

61. Subbe, C.P.; Jishi, F.; Hibbs, R.A. The simple clinical score: a tool for benchmarking of emergency admissions in acute internal medicine. Clinical medicine (London, England) 2010, 10, 352-357, doi:10.7861/clinmedicine.10-4-352.

62. Yu, S.; Leung, S.; Heo, M.; Soto, G.J.; Shah, R.T.; Gunda, S.; Gong, M.N. Comparison of risk prediction scoring systems for ward patients: a retrospective nested case-control study. Crit Care 2014, 18, R132, doi:10.1186/cc13947.

63. Allegretti, A.S.; Steele, D.J.; David-Kasdan, J.A.; Bajwa, E.; Niles, J.L.; Bhan, I. Continuous renal replacement therapy outcomes in acute kidney injury and end-stage renal disease: a cohort study. Crit Care 2013, 17, R109, doi:10.1186/cc12780.

64. Bethea, A.; Seidler, D.; Coleman, C.; Johnson, K.; Davis, E.; Thompson, S. Prehospital identification of elevated lactic acid levels and sepsis-related outcomes (lasr study). Crit Care Med 2018, 46, 687, doi:10.1097/01.ccm.0000529407.05908.9b.

65. Cardona, M.; Lewis, E.T.; Kristensen, M.R.; Skjøt-Arkil, H.; Ekmann, A.A.; Nygaard, H.H.; Jensen, J.J.; Jensen, R.O.; Pedersen, J.L.; Turner, R.M., et al. Predictive validity of the CriSTAL tool for short-term mortality in older people presenting at Emergency Departments: a prospective study. Eur Geriatr Med 2018, 9, 891-901, doi:10.1007/s41999-018-0123-6.

66. Haas, L.; Eckart, A.; Haubitz, S.; Mueller, B.; Schuetz, P.; Segerer, S. Estimated glomerular filtration rate predicts 30-day mortality in medical emergency departments: Results of a prospective multi-national observational study. PloS one 2020, 15, e0230998-e0230998, doi:10.1371/journal.pone.0230998.

67. Hutchison, C.A.; Crowe, A.V.; Stevens, P.E.; Harrison, D.A.; Lipkin, G.W. Case mix, outcome and activity for patients admitted to intensive care units requiring chronic renal dialysis: a secondary analysis of the ICNARC Case Mix Programme Database. Crit Care 2007, 11, R50, doi:10.1186/cc5785.

68. Wallis, S.J.; Wall, J.; Biram, R.W.; Romero-Ortuno, R. Association of the clinical frailty scale with hospital outcomes. Qjm 2015, 108, 943-949, doi:10.1093/qjmed/hcv066.

69. Lim, W.S.; van der Eerden, M.M.; Laing, R.; Boersma, W.G.; Karalus, N.; Town, G.I.; Lewis, S.A.; Macfarlane, J.T. Defining community acquired pneumonia severity on presentation to hospital: an international derivation and validation study. Thorax 2003, 58, 377, doi:10.1136/thorax.58.5.377.

70. Marwick, C.A.; Guthrie, B.; Pringle, J.E.; McLeod, S.R.; Evans, J.M.; Davey, P.G. Identifying which septic patients have increased mortality risk using severity scores: a cohort study. BMC Anesthesiol 2014, 14, 1, doi:10.1186/1471-2253-14-1.

71. Stræde, M.; Brabrand, M. External validation of the simple clinical score and the HOTEL score, two scores for predicting short-term mortality after admission to an acute medical unit. PloS one 2014, 9, e105695, doi:10.1371/journal.pone.0105695.

72. Tabak, Y.P.; Sun, X.; Hyde, L.; Yaitanes, A.; Derby, K.; Johannes, R.S. Using enriched observational data to develop and validate age-specific mortality risk adjustment models for hospitalized pediatric patients. Med Care 2013, 51, 437-445, doi:10.1097/MLR.0b013e318287d57d.

73. van Walraven C; McAlister FA; Bakal JA; Hawken S; Donzé J. External validation of the Hospital-patient One-year Mortality Risk (HOMR) model for predicting death within 1 year after hospital admission. Cmaj 2015, 187, 725-733.

74. Heyland, D.K.; Davidson, J.; Skrobik, Y.; des Ordons, A.R.; Van Scoy, L.J.; Day, A.G.; VandallWalker, V.; Marshall, A.P. Improving partnerships with family members of ICU patients: 
medRxiv preprint doi: https://doi.org/10.1101/2020.09.20.20198184; this version posted September 23, 2020. The copyright holder for this preprint (which was not certified by peer review) is the author/funder, who has granted medRxiv a license to display the preprint in perpetuity.

All rights reserved. No reuse allowed without permission.

study protocol for a randomized controlled trial. Trials 2018, 19, 3, doi:10.1186/s13063-0172379-4.

75. Einav, S.; Hick, J.L.; Hanfling, D.; Erstad, B.L.; Toner, E.S.; Branson, R.D.; Kanter, R.K.; Kissoon, N.; Dichter, J.R.; Devereaux, A.V., et al. Surge capacity logistics: care of the critically ill and injured during pandemics and disasters: CHEST consensus statement. Chest 2014, 146, e17S43S, doi:https://dx.doi.org/10.1378/chest.14-0734.

76. Murray, S.A.; Kendall, M.; Boyd, K.; Sheikh, A. Illness trajectories and palliative care. BMJ (Clinical research ed.) 2005, 330, 1007-1011, doi:10.1136/bmj.330.7498.1007.

77. Heyland, D.K.; Stelfox, H.T.; Garland, A.; Cook, D.; Dodek, P.; Kutsogiannis, J.; Jiang, X.; Turgeon, A.F.; Day, A.G.; on behalf of the Canadian Critical Care Trials, G., et al. Predicting Performance Status 1 Year After Critical Illness in Patients 80 Years or Older: Development of a Multivariable Clinical Prediction Model. Crit Care Med 2016, 44.

78. Adeniji, K.; Cusack, R.; Golder, K. The simple triage scoring system (STSS) successfully predicts mortality and critical care resource utilisation in H1N1 pandemic flu. Intensive Care Medicine 2010, 36, S286, doi:10.1007/s00134-010-2000-8.

79. World Health Organization. Clinical management of COVID-19. Interim guidance; WHO/2019-nCoV/clinical/2020.5; 2020; p 62.

80. Australia and New Zealand Intensive Care Society. [web report] Guiding principles for complex decision making during Pandemic COVID-19. Version 2.0. Availabe online: https://www.anzics.com.au/wp-content/uploads/2020/04/ANZI 3367 Guidelines V2.pdf (accessed on June).

81. Winsor, S.; Bensimon, C.M.; Sibbald, R.; Anstey, K.; Chidwick, P.; Coughlin, K.; Cox, P.; Fowler, R.; Godkin, D.; Greenberg, R.A., et al. Identifying prioritization criteria to supplement critical care triage protocols for the allocation of ventilators during a pandemic influenza. Healthc $Q$ 2014, 17, 44-51.

82. Minne, L.; Abu-Hanna, A.; de Jonge, E. Evaluation of SOFA-based models for predicting mortality in the ICU: A systematic review. Crit Care 2008, 12, R161, doi:10.1186/cc7160.

83. Alam, A.; Gupta, S. Lactate Measurements and Their Association With Mortality in Pediatric Severe Sepsis in India: Evidence That 6-Hour Level Performs Best. J Intensive Care Med 2020, 10.1177/0885066620903231, 885066620903231, doi:10.1177/0885066620903231.

84. Bozcuk, H.; Koyuncu, E.; Yildiz, M.; Samur, M.; Ozdogan, M.; Artaç, M.; Coban, E.; Savas, B. A simple and accurate prediction model to estimate the intrahospital mortality risk of hospitalised cancer patients. Int J Clin Pract 2004, 58, 1014-1019, doi:10.1111/j.17421241.2004.00169.x.

85. Rothstein, M.A. Currents in contemporary ethics. Should health care providers get treatment priority in an influenza pandemic? J Law Med Ethics 2010, 38, 412-419, doi:10.1111/j.1748720X.2010.00499.x.

86. Daugherty, E.L.; Rubinson, L. Preparing your intensive care unit to respond in crisis: considerations for critical care clinicians. Crit Care Med 2011, 39, 2534-2539, doi:https://dx.doi.org/10.1097/CCM.0b013e3182326440.

87. Patel JJ; Heyland DK. Unmasking the triumphs, tragedies and opportunities of the COVID-19 pandemic. ICU Management and Practice 2020, 3.

88. Van Scoy, L.J.; Chiarolanzio, P.J.; Kim, C.; Heyland, D.K. Development and initial evaluation of an online decision support tool for families of patients with critical illness: A multicenter pilot study. J Crit Care 2017, 39, 18-24, doi:10.1016/j.jcrc.2016.12.022.

89. Bion J; Dennis A. ICU admission and discharge criteria. In Oxford Textbook of critical care, 2nd ed.; Oxford University Press: 2016; 10.1093/med/9780199600830.003.0020.

90. Mareiniss, D.P.; Levy, F.; Regan, L. ICU triage: the potential legal liability of withdrawing ICU care during a catastrophic event. Am J Disaster Med 2011, 6, 329-338.

91. Hick JL; Hanfling D; Wynia MK; Pavia AT. Duty to Plan: Health Care, Crisis Standards of Care, and Novel Coronavirus SARS-CoV-2. NAM Perspectives. Discussion paper. . National 
medRxiv preprint doi: https://doi.org/10.1101/2020.09.20.20198184; this version posted September 23, 2020. The copyright holder for this preprint (which was not certified by peer review) is the author/funder, who has granted medRxiv a license to display the preprint in perpetuity.

All rights reserved. No reuse allowed without permission.

Academy of Medicine 2020, https://doi.org/10.31478/202003b, doi:https://doi.org/10.31478/202003b.

92. Fadul, N.; Elsayem, A.F.; Bruera, E. Integration of palliative care into COVID-19 pandemic planning. BMJ Supportive \&amp;amp; Palliative Care 2020, 10.1136/bmjspcare-2020002364, bmjspcare-2020-002364, doi:10.1136/bmjspcare-2020-002364.

93. New York State Task Force on Life \& the Law. Ventilator allocation guidelines. New York State Department of Health: New York, USA, 2015; p 266 pp.

94. Biddison, L.D.; Berkowitz, K.A.; Courtney, B.; De Jong, C.M.; Devereaux, A.V.; Kissoon, N.; Roxland, B.E.; Sprung, C.L.; Dichter, J.R.; Christian, M.D., et al. Ethical considerations: care of the critically ill and injured during pandemics and disasters: CHEST consensus statement. Chest 2014, 146, e145S-155S, doi:https://dx.doi.org/10.1378/chest.14-0742.

95. Clayton, J.M.; Hancock, K.M.; Butow, P.N.; Tattersall, M.H.; Currow, D.C.; Adler, J.; Aranda, S.; Auret, K.; Boyle, F.; Britton, A., et al. Clinical practice guidelines for communicating prognosis and end-of-life issues with adults in the advanced stages of a life-limiting illness, and their caregivers. The Medical journal of Australia 2007, 186, S77-s105.

96. Mercadante, S.; Gregoretti, C.; Cortegiani, A. Palliative care in intensive care units: why, where, what, who, when, how. BMC Anesthesiology 2018, 18, 106, doi:10.1186/s12871-0180574-9.

97. Braganza MA; Glossop A; Vora VA. Treatment withdrawal and end-of-life care in the intensive care unit. BJA Education 2017, 17, 396-400.

98. Silva, D.S.; Gibson, J.L.; Robertson, A.; Bensimon, C.M.; Sahni, S.; Maunula, L.; Smith, M.J. Priority setting of ICU resources in an influenza pandemic: a qualitative study of the Canadian public's perspectives. BMC public health 2012, 12, 241, doi:10.1186/1471-2458-12241.

99. Silva, D.S.; Nie, J.X.; Rossiter, K.; Sahni, S.; Upshur, R.E. Contextualizing ethics: ventilators, H1N1 and marginalized populations. Healthcare quarterly (Toronto, Ont.) 2010, 13, 32-36, doi:10.12927/hcq.2013.21613.

100. Australasian College of Emergency Medicine. Clinical Guidelines for the management of COVID-19 in AUstralasian Emergency Depratments. Availabe online: https://acem.org.au/getmedia/78105c4b-5195-43f6-9c91-25dda5604eaf/Clinical-Guidelines (accessed on v3.0).

101. Australia and New Zealand Intensive Care Society. COVID-19 Guidelines version 2. Availabe online: https://www.anzics.com.au/wpcontent/uploads/2020/04/ANZI 3367 Guidelines V2.pdf (accessed on

102. Sprung, C.L.; Zimmerman, J.L.; Christian, M.D.; Joynt, G.M.; Hick, J.L.; Taylor, B.; Richards, G.A.; Sandrock, C.; Cohen, R.; Adini, B., et al. Recommendations for intensive care unit and hospital preparations for an influenza epidemic or mass disaster: summary report of the European Society of Intensive Care Medicine's Task Force for intensive care unit triage during an influenza epidemic or mass disaster. Intensive Care Med 2010, 36, 428-443, doi:https://dx.doi.org/10.1007/s00134-010-1759-y.

103. Challen, K.; Bentley, A.; Bright, J.; Walter, D. Clinical review: mass casualty triage--pandemic influenza and critical care. Crit Care 2007, 11, 212.

104. Haniffa, R.; Mukaka, M.; Munasinghe, S.B.; De Silva, A.P.; Jayasinghe, K.S.A.; Beane, A.; de Keizer, N.; Dondorp, A.M. Simplified prognostic model for critically ill patients in resource limited settings in South Asia. Crit Care 2017, 21, 250, doi:10.1186/s13054-017-1843-6. 


\title{
ONLINE SUPPLEMENTS 1 and 2
}

\section{Title: Supporting decision-making on allocation of ICU beds and ventilators in pandemics}

Authors: Magnolia Cardona, PhD, MBBS, ${ }^{1,2 *}$ Claudia C. Dobler MD, PhD, ${ }^{1,3,6}$ Eyza Koreshe MPH, BSc, ${ }^{4}$ Daren K Heyland, MD, FRCPC ${ }^{5}$ Rebecca Nguyen, ${ }^{6}$ Joan P.Y. Sim, ${ }^{6}$ Justin Clark, BA, ${ }^{1}$ Alex Psirides MBBS, FCICM. ${ }^{7}$

\author{
Affiliations \\ ${ }^{1}$ Institute for Evidence-Based Healthcare, Bond University Gold Coast, Queensland, Australia \\ ${ }^{2}$ Gold Coast University Hospital, Southport, Queensland, Australia \\ ${ }^{3}$ Evidence-Based Practice Center, Robert D. and Patricia E. Kern Center for the Science of \\ Health Care Delivery, Mayo Clinic, Minnesota, USA \\ ${ }^{4}$ Boden Institute, University of Sydney, NSW, Australia \\ ${ }^{5}$ Department of Critical Care Medicine, Queens University, Kingston, Ontario, Canada \\ ${ }^{6}$ The University of New South Wales, South Westefn Sydney Clinical School, NSW Australia \\ ${ }^{7}$ Intensive Care Unit, Wellington Regional Hospital, Wellington, New Zealand
}

\begin{tabular}{|l|l|}
\hline Supplement 1. Table S1.1 Detailed Search strategy & pages 2-3 \\
\hline Supplement 1, Table S1.2. Reasons for exclusion after full text screening & pages 4-6 \\
\hline $\begin{array}{l}\text { Supplement 1, Table S1.3 Characteristics of publications informing ICU Triage in } \\
\text { pandemic situations. N= 16 }\end{array}$ & pages 7-8 \\
\hline $\begin{array}{l}\text { Supplement 1, Table S1.4 Characteristics of publications on prognostic tools for } \\
\text { risk of death in routine clinical care potentially applicable to ICU triage in } \\
\text { pandemics (N= 46) }\end{array}$ & pages 9-12 \\
\hline $\begin{array}{l}\text { Supplement 2. Table S2.1 Validation status, study types and clinical parameters } \\
\text { predicting poor outcome for potentially guidance on ICU admission or discharge } \\
\text { during pandemics } \mathbf{N}=16)\end{array}$ & pages $13-19$ \\
\hline $\begin{array}{l}\text { Supplement 2. Table S2.2 Validation status, and clinical parameters predicting } \\
\text { poor outcome for potentially guidance on ICU admission or discharge derived } \\
\text { from routine care studies in ICU, ED or wards(N= 46 studies) }\end{array}$ & $20-36$ \\
\hline
\end{tabular}


medRxiv preprint doi: https://doi.org/10.1101/2020.09.20.20198184; this version posted September 23 , 2020. The copyright holder for this preprint (which was not certified by peer review) is the author/funder, who has granted medRxiv a license to display the preprint in

All rights reserved. No reuse allowed without permission.

Supplement 1. Table S1.1 Detailed Search strategy Searches run 14/05/2020:

\section{PubMed}

("Resource Allocation"[Mesh] OR Resource[tiab] OR Resources[tiab] OR Allocation[tiab]

OR Demand[tiab] OR “Prognostic certainty"[tiab] OR “External validation"[tiab] OR

Prognosticative[tiab] OR Prognosticating[tiab] OR "Validation cohort"[tiab])

AND

("Decision rule"[tiab] OR "Decision Support"[tiab] OR Prediction[tiab] OR Predictions[tiab] OR Predictor[tiab] OR Predicting[tiab] OR Predictive[tiab] OR "Scoring systems"[tiab] OR

"Scoring system"[tiab] OR "Decision making"[tiab] OR "Preparedness strategies"[tiab] OR

"Preparedness strategy"[tiab] OR "Prioritization Criteria"[tiab] OR "Prioritizing access"[tiab]

OR “Consensus Statement”"[tiab] OR "Categorization decisions"[tiab] OR “Allocation

decisions"[tiab] OR "Clinical guidelines"[tiab])

AND

("Triage"[Mesh] OR "Patient Selection"[Mesh] OR Triage[tiab] OR Triaging[tiab] OR Admission[tiab] OR Discharge[tiab] OR "Incident management"[tiab] OR "Treatment priority"[tiab] OR "Patient volumes"[tiab] OR ((Managing[tiab]) AND (Cohort[tiab])) OR (Calculators[tiab] AND Patients[tiab]))

AND

("Emergency Medical Services"[Mesh] OR "Critical Care"[Mesh] OR "Intensive Care Units"[Mesh] OR "Intensive care"[tiab] OR “Critical care"[tiab] OR ICU[tiab] OR PICU[tiab] OR “Critically ill”"[tiab] OR "Life saving”[tiab] OR Life-saving[tiab] OR Lifesustaining[tiab] OR "Life sustaining"[tiab] OR "Life support"[tiab] OR "Short-term death"[tiab] OR "Short term death"[tiab] OR "Death prediction"[tiab] OR Hospital[tiab] OR Hospitals[tiab] OR "Emergency department"[tiab] OR "Emergency departments"[tiab]) AND

("Pandemics"[Mesh] OR Disasters[Mesh] OR "Hospital Mortality"[Mesh] OR "COVID19"[nm] OR Pandemic[tiab] OR Pandemics[tiab] OR Disaster[tiab] OR Disasters[tiab] OR “SARS CoV 2"[tiab] OR “COVID 19"[tiab] OR “COVID-19”[tiab] OR "Mass casualty"[tiab] OR "Severe sepsis"[tiab] OR "Septic shock”[tiab] OR "Short-term mortality"[tiab])

\section{Embase}

('Resource Allocation'/exp OR Resource:ti,ab OR Resources:ti,ab OR Allocation:ti,ab OR Demand:ti,ab OR "Prognostic certainty":ti,ab OR "External validation":ti,ab OR Prognosticative:ti,ab OR Prognosticating:ti,ab OR "Validation cohort":ti,ab)

AND

("Decision rule":ti,ab OR "Decision Support":ti,ab OR Prediction:ti,ab OR Predictions:ti,ab OR Predictor:ti,ab OR Predicting:ti,ab OR Predictive:ti,ab OR "Scoring systems":ti,ab OR "Scoring system":ti,ab OR "Decision making":ti,ab OR "Preparedness strategies":ti,ab OR "Preparedness strategy":ti,ab OR "Prioritization Criteria":ti,ab OR "Prioritizing access":ti,ab OR "Consensus Statement":ti,ab OR "Categorization decisions":ti,ab OR "Allocation decisions":ti,ab OR "Clinical guidelines":ti,ab)

AND

('Patient Selection'/exp/mj OR Triage:ti,ab OR Triaging:ti,ab OR Admission:ti,ab OR Discharge:ti,ab OR "Incident management":ti,ab OR "Treatment priority":ti,ab OR "Patient volumes":ti,ab OR ((Managing:ti,ab) AND (Cohort:ti,ab)) OR (Calculators:ti,ab AND Patients:ti,ab)) 
medRxiv preprint doi: https://doi.org/10.1101/2020.09.20.20198184; this version posted September 23 , 2020. The copyright holder for this preprint (which was not certified by peer review) is the author/funder, who has granted medRxiv a license to display the preprint in All rights reserved. No reuse allowed without permission.

\section{AND}

('Emergency Medical Service'/exp OR 'intensive care'/exp OR 'Intensive Care Unit'/exp OR "Intensive care":ti,ab OR "Critical care":ti,ab OR ICU:ti,ab OR PICU:ti,ab OR "Critically ill":ti,ab OR "Life saving":ti,ab OR Life-saving:ti,ab OR Life-sustaining:ti,ab OR "Life sustaining":ti,ab OR "Life support":ti,ab OR "Short-term death":ti,ab OR "Short term death":ti,ab OR "Death prediction":ti,ab OR Hospital:ti,ab OR Hospitals:ti,ab OR "Emergency department":ti,ab OR "Emergency departments":ti,ab)

AND

('Pandemic'/exp OR 'Disaster'/exp OR 'Hospital Mortality'/exp OR Pandemic:ti,ab OR Pandemics:ti,ab OR Disaster:ti,ab OR Disasters:ti,ab OR "SARS CoV 2":ti,ab OR "COVID 19":ti,ab OR COVID-19:ti,ab OR "Mass casualty":ti,ab OR "Severe sepsis":ti,ab OR "Septic shock":ti,ab OR "Short-term mortality":ti,ab) 
medRxiv preprint doi: https://doi.org/10.1101/2020.09.20.20198184; this version posted September 23, 2020. The copyright holder for this preprint (which was not certified by peer review) is the author/funder, who has granted medRxiv a license to display the preprint in perpetuity.

All rights reserved. No reuse allowed without permission.

\section{Supplement 1, Table S1.2. Reasons for exclusion after full text screening $\mathbf{N}=70$}

\begin{tabular}{|c|c|}
\hline \multirow{2}{*}{$\begin{array}{l}\text { No objective parameters } \\
\text { Barrera, R., et al. (2001). "Accuracy of predictions of survival at admission to the intensive care unit." J Crit Care } \\
\text { 16(1): 32-35. }\end{array}$} & $\mathrm{N}=9$ \\
\hline & \\
\hline \multicolumn{2}{|l|}{$\begin{array}{l}\text { Burkle, F. M., Jr. (2006). "Population-based triage management in response to surge-capacity requirements during a } \\
\text { large-scale bioevent disaster." Acad Emerg Med 13(11): 1118-1129. }\end{array}$} \\
\hline \multicolumn{2}{|l|}{$\begin{array}{l}\text { Christian, M. D., et al. (2014). "Triage: care of the critically ill and injured during pandemics and disasters: CHEST } \\
\text { consensus statement." Chest 146(4 Suppl): e61S-74S. }\end{array}$} \\
\hline \multicolumn{2}{|l|}{$\begin{array}{l}\text { Dadoun, A., et al. (2017). "Invoking the "expectant" triage category: Can we make the paradigm shift?" Am J Disaster } \\
\text { Med 12(3): 167-172. }\end{array}$} \\
\hline \multicolumn{2}{|l|}{$\begin{array}{l}\text { Einav, S., et al. (2014). "Surge capacity logistics: care of the critically ill and injured during pandemics and disasters: } \\
\text { CHEST consensus statement." Chest 146(4 Suppl): e17S-43S. }\end{array}$} \\
\hline \multicolumn{2}{|l|}{$\begin{array}{l}\text { Fink, S. L. (2010). "Worst case: rethinking tertiary triage protocols in pandemics and other health emergencies." Crit } \\
\text { Care 14(1): 103. }\end{array}$} \\
\hline \multicolumn{2}{|l|}{$\begin{array}{l}\text { Godfrey, G., et al. (2012). "Treatment limitations at admission to intensive care units in Australia and New Zealand: } \\
\text { prevalence, outcomes, and resource use*." Crit Care Med 40(7): 2082-2089. }\end{array}$} \\
\hline \multicolumn{2}{|l|}{$\begin{array}{l}\text { Prekker ME, et al., (2020) Regional planning for extracorporeal memberane oxygenation allocation during } \\
\text { Coronavirus disease 2019. Chest 158(2):603-607. }\end{array}$} \\
\hline \multicolumn{2}{|l|}{$\begin{array}{l}\text { Ravikumar N, et al (2020) Novel Coronavirus (2019-nCoV) Infection: Part I - Preparedeness and Management in the } \\
\text { pediatric intensive care unit in resource-limited settings. Indian Pediatrics April 15, p324-334 }\end{array}$} \\
\hline No validation or regression & $\mathrm{N}=8$ \\
\hline \multicolumn{2}{|l|}{$\begin{array}{l}\text { Antommaria, A. H., et al. (2020)."Ventilator Triage Policies During the COVID-19 Pandemic at U.S. Hospitals } \\
\text { Associated With Members of the Association of Bioethics Program Directors." Ann Intern Med. }\end{array}$} \\
\hline \multicolumn{2}{|l|}{$\begin{array}{l}\text { Baysan, M., et al. (2020). "The Added Value of Lactate and Lactate Clearance in Prediction of In-Hospital Mortality in } \\
\text { Critically III Patients With Sepsis." Crit Care Explor 2(3): e0087. }\end{array}$} \\
\hline \multicolumn{2}{|l|}{$\begin{array}{l}\text { Cowen, M. E., et al. (2014). "Implementation of a mortality prediction rule for real-time decision making: feasibility } \\
\text { and validity." J Hosp Med 9(11): 720-726 }\end{array}$} \\
\hline \multicolumn{2}{|l|}{$\begin{array}{l}\text { Dziadzko, M. A., et al. (2018). "Multicenter derivation and validation of an early warning score for acute respiratory } \\
\text { failure or death in the hospital." Crit Care 22(1): } 286 .\end{array}$} \\
\hline \multicolumn{2}{|l|}{$\begin{array}{l}\text { Hahn, R., et al. (2009). "Use of pediatric risk of mortality (PRISM) II score as a tool for critical care triage during a } \\
\text { pandemic." Critical Care Medicine 37(12): A327. }\end{array}$} \\
\hline \multicolumn{2}{|l|}{$\begin{array}{l}\text { Hick J. L., et al. (2007) Clinical review: Allocating ventilators during large-scale disasters - problems, planning, and } \\
\text { process }\end{array}$} \\
\hline \multicolumn{2}{|l|}{$\begin{array}{l}\text { Thomas, D. R., et al. (2005). "The relationship of functional status, nutritional assessment, and severity of illness to } \\
\text { in-hospital mortality." J Nutr Health Aging 9(3): 169-175 }\end{array}$} \\
\hline \multicolumn{2}{|l|}{$\begin{array}{l}\text { Thakur, M., et al. (2016). "Intensive Care Admissions in Pregnancy: Analysis of a Level of Support Scoring System." } \\
\text { Matern Child Health J 20(1): 106-113. }\end{array}$} \\
\hline Abstract/Poster Presentation-insufficient information & $\mathrm{N}=9$ \\
\hline \multicolumn{2}{|l|}{$\begin{array}{l}\text { Acton, C., et al. (2016). "Ten patients, one ventilator: How to best allocate critical care resources during mass } \\
\text { disaster." Canadian Journal of Emergency Medicine 18: S79. }\end{array}$} \\
\hline \multicolumn{2}{|l|}{$\begin{array}{l}\text { Adeniji, K., et al. (2010). "The simple triage scoring system (STSS) successfully predicts mortality and critical care } \\
\text { resource utilisation in H1N1 pandemic flu." Intensive Care Medicine 36: S286. }\end{array}$} \\
\hline \multicolumn{2}{|l|}{$\begin{array}{l}\text { Allareddy, V., et al. (2018). "Use of ecmo and associated outcomes in children hospitalized for sepsis in the United } \\
\text { States." Critical Care Medicine 46: } 744 .\end{array}$} \\
\hline \multicolumn{2}{|l|}{$\begin{array}{l}\text { Aluvaala, M. J., et al. (2018). "Predicting in-hospital mortality using routine data to guide decision making for } \\
\text { essential neonatal care." American Journal of Tropical Medicine and Hygiene 99(4): } 450 .\end{array}$} \\
\hline \multicolumn{2}{|l|}{ Flaatten, H. (2009). "ICU triage: An overview." Acta Anaesthesiologica Scandinavica 53: 17-18. } \\
\hline \multicolumn{2}{|l|}{$\begin{array}{l}\text { Marriott, D., et al. (2012) "To admit or not to admit? The suitability of critical care admission criteria." Crit Care 16, } \\
\text { P511 }\end{array}$} \\
\hline \multicolumn{2}{|l|}{$\begin{array}{l}\text { Nobre de Jesus et al (2019) “Clinical outcome prediction after admission in intermediate level critical care unit:role of } \\
\text { severity scores." Critical Care 23(Suppl 2):72, poster } 466\end{array}$} \\
\hline \multicolumn{2}{|l|}{$\begin{array}{l}\text { Soliman, I. W., et al. (2017). "Long-term prognostication in the ICU: A systematic review into available prediction } \\
\text { models." Intensive Care Medicine Experimental 5(2). }\end{array}$} \\
\hline \multicolumn{2}{|l|}{$\begin{array}{l}\text { Soong, J. T. Y., et al. (2017). "Frailty syndromes coded within secondary user service(SUS) data predict inpatient } \\
\text { mortality and long length of stay." Acute Medicine } 16(3): 131-132 .\end{array}$} \\
\hline Ethical/resource/preparedness focus & $\mathbf{N}=11$ \\
\hline \multicolumn{2}{|l|}{$\begin{array}{l}\text { Australasian College of Emergency Medicine. "Clinical Guidelines for the management of COVID-19 in Australasian } \\
\text { Emergency Departments". Melbourne VIC: ACEM, 2020, p. } 112 .\end{array}$} \\
\hline- & \\
\hline
\end{tabular}


medRxiv preprint doi: https://doi.org/10.1101/2020.09.20.20198184; this version posted September 23, 2020. The copyright holder for this preprint (which was not certified by peer review) is the author/funder, who has granted medRxiv a license to display the preprint in perpetuity.

All rights reserved. No reuse allowed without permission.

\begin{tabular}{|c|c|}
\hline $\begin{array}{l}\text { Antommaria, A. H., et al. (2011). "Ethical issues in pediatric emergency mass critical care." Pediatr Crit Care Med 12(6 } \\
\text { Suppl): S163-168. }\end{array}$ & \\
\hline $\begin{array}{l}\text { Barnett, D. J., et al. (2009). Resource allocation on the frontlines of public health preparedness and response: report } \\
\text { of a summit on legal and ethical issues. Public Health Rep } 124(2): 295-303 .\end{array}$ & \\
\hline $\begin{array}{l}\text { Biddison, L. D., et al. (2014). "Ethical considerations: care of the critically ill and injured during pandemics and } \\
\text { disasters: CHEST consensus statement." Chest 146(4 Suppl): e145S-155S. }\end{array}$ & \\
\hline $\begin{array}{l}\text { Challen K, et al., (2007) “Clinical review: mass casualty triage - pandemic influenza and critical care”. Critical Care } \\
11: 212,6 p p\end{array}$ & \\
\hline $\begin{array}{l}\text { Farrell, T. W., et al. (2020). "AGS Position Statement: Resource Allocation Strategies and Age-Related Considerations } \\
\text { in the COVID-19 Era and Beyond." J Am Geriatr Soc. }\end{array}$ & \\
\hline $\begin{array}{l}\text { Flaatten, H., et al. (2017). "The status of intensive care medicine research and a future agenda for very old patients in } \\
\text { the ICU." Intensive Care Med 43(9): 1319-1328. }\end{array}$ & \\
\hline $\begin{array}{l}\text { Ghanbari, V., et al. (2019). "Ethical prioritization of patients during disaster triage: A systematic review of current } \\
\text { evidence." Int Emerg Nurs 43: 126-132. }\end{array}$ & \\
\hline $\begin{array}{l}\text { Kanter, R. K., \& Cooper, A. (2009). Mass critical care: pediatric considerations in extending and rationing care in } \\
\text { public health emergencies. Disaster medicine and public health preparedness, 3(S2), S166-S171. }\end{array}$ & \\
\hline $\begin{array}{l}\text { Maves RC, et al., (2020) "Triage of scarce critical resources in COVID-19. An implementation guide for regional } \\
\text { allocation". Chest 158(1):212-225 }\end{array}$ & \\
\hline Modelling study/no primary data & $\mathrm{N}=11$ \\
\hline $\begin{array}{l}\text { Abir, M., et al. (2013). "Design of a model to predict surge capacity bottlenecks for burn mass casualties at a large } \\
\text { academic medical center." Prehosp Disaster Med 28(1): 23-32. }\end{array}$ & \\
\hline $\begin{array}{l}\text { Amram, O., et al. (2012). "A web-based model to support patient-to-hospital allocation in mass casualty incidents." J } \\
\text { Trauma Acute Care Surg 72(5): 1323-1328. }\end{array}$ & \\
\hline $\begin{array}{l}\text { Bolt, S. and R. Sparks (2013). "Detecting and diagnosing hotspots for the enhanced management of hospital } \\
\text { Emergency Departments in Queensland, Australia." BMC Med Inform Decis Mak 13: } 132 .\end{array}$ & \\
\hline $\begin{array}{l}\text { Enfield, K., et al. (2011). "Limited utility of SOFA and APACHE II prediction models for ICU triage in pandemic } \\
\text { influenza." Chest 140(4). }\end{array}$ & \\
\hline $\begin{array}{l}\text { Ercole, A., et al. (2009). "Modelling the impact of an influenza A/H1N1 pandemic on critical care demand from early } \\
\text { pathogenicity data: the case for sentinel reporting." Anaesthesia 64(9): 937-941. }\end{array}$ & \\
\hline $\begin{array}{l}\text { Gall, C., et al. (2016). "Pediatric Triage in a Severe Pandemic: Maximizing Survival by Establishing Triage Thresholds." } \\
\text { Crit Care Med 44(9): 1762-1768. }\end{array}$ & \\
\hline $\begin{array}{l}\text { Kanter, R. K. (2015). "Would triage predictors perform better than first-come, first-served in pandemic ventilator } \\
\text { allocation?" Chest 147(1): 102-108. }\end{array}$ & \\
\hline Nap, R. E., et al. (2007). "Pandemic influenza and hospital resources." Emerg Infect Dis 13(11): 1714-1719. & \\
\hline $\begin{array}{l}\text { Toltzis P, Soto-Campos G, Kuhn E, Wetzel R. A pediatric triage scheme to guide resource allocation in a mass casualty. } \\
\text { Critical Care Medicine. } 2013 ; 41(12) \text { :A148. }\end{array}$ & \\
\hline $\begin{array}{l}\text { Steinberg DO, et al. (2020) Critical review: COVID-19 calculators during extreme resource -limited situations. Emerg } \\
\text { Medicine Pract 22(5):5pp }\end{array}$ & \\
\hline $\begin{array}{l}\text { Toltzis P, Soto-Campos G, Shelton C, Kuhn EM, Hahn R, Kanter RK, et al. Evidence-Based Pediatric Outcome } \\
\text { Predictors to Guide the Allocation of Critical Care Resources in a Mass Casualty Event. Pediatr Crit Care Med. } 2015 \\
\text { Sep;16(7):e207-16. }\end{array}$ & \\
\hline Non-Western health system & $\mathrm{N}=6$ \\
\hline $\begin{array}{l}\text { Alam A, Gupta S. Lactate Measurements and Their Association With Mortality in Pediatric Severe Sepsis in India: } \\
\text { Evidence That 6-Hour Level Performs Best. J Intensive Care Med. } 2020\end{array}$ & \\
\hline $\begin{array}{l}\text { Arshad A, Ayaz A, Haroon MA, Jamil B, Hussain E. Frequency and Cause of Readmissions in Sepsis Patients Presenting } \\
\text { to a Tertiary Care Hospital in a Low Middle Income Country. Crit Care Explor. } 2020 \text { Feb;2(2):e0080. }\end{array}$ & \\
\hline $\begin{array}{l}\text { Santana AR, Amorim FF, Menezes BM, Soares FB, Araújo FVB, De Souza JL, et al. Serum arterial lactate at the time of } \\
\text { admission as a predictor of mortality in patients admitted with severe sepsis and septic shock to an ICU. Critical Care. } \\
\text { 2013;17:P47. }\end{array}$ & \\
\hline $\begin{array}{l}\text { Ytzhak A, Sagi R, Bader T, Assa A, Farfel A, Merin O, et al. Pediatric ventilation in a disaster: clinical and ethical } \\
\text { decision making. Crit Care Med. } 2012 \text { Feb;40(2):603-7. }\end{array}$ & \\
\hline $\begin{array}{l}\text { Dumas, G., et al. (2019). "Mottling score is a strong predictor of 14-day mortality in septic patients whatever } \\
\text { vasopressor doses and other tissue perfusion parameters." Crit Care 23(1): } 211 .\end{array}$ & \\
\hline $\begin{array}{l}\text { Yussof SJ, Zakaria MI, Mohamed FL, Bujang MA, Lakshmanan S, Asaari AH. Value of Shock Index in prognosticating } \\
\text { the short-term outcome of death for patients presenting with severe sepsis and septic shock in the emergency } \\
\text { department. Med J Malaysia. } 2012 \text { Aug;67(4):406-11. }\end{array}$ & \\
\hline Other disease/treatment specific & $\mathrm{N}=4$ \\
\hline $\begin{array}{l}\text { Barbaro, R. P., et al. (2016). "Development and validation of the pediatric risk estimate score for children using } \\
\text { extracorporeal respiratory support (Ped-RESCUERS)." Intensive Care Med 42(5): 879-888 }\end{array}$ & \\
\hline $\begin{array}{l}\text { Bozcuk H, Koyuncu E, Yildiz M, Samur M, Ozdogan M, Artaç M, et al. A simple and accurate prediction moc } \\
\text { estimate the intrahospital mortality risk of hospitalised cancer patients. Int J Clin Pract. } 2004 \text { Nov;58(11):1 }\end{array}$ & \\
\hline
\end{tabular}


medRxiv preprint doi: https://doi.org/10.1101/2020.09.20.20198184; this version posted September 23, 2020. The copyright holder for this preprint (which was not certified by peer review) is the author/funder, who has granted medRxiv a license to display the preprint in perpetuity.

All rights reserved. No reuse allowed without permission.

\begin{tabular}{|c|c|}
\hline $\begin{array}{l}\text { Cheng, L., et al. (2015). "An evaluation of laboratory data at admission for predicting mortality among critically ill } \\
\text { patients with cancer." Cancer Research 75(15). }\end{array}$ & \\
\hline $\begin{array}{l}\text { Agulnik, A., et al. (2017). "Validation of a pediatric early warning system for hospitalized pediatric oncology patients } \\
\text { in a resource-limited setting." Cancer } 123(24): 4903-4913\end{array}$ & \\
\hline Injury/surgical triage & $\mathrm{N}=3$ \\
\hline $\begin{array}{l}\text { Chang, C. J., et al. (2013). "Predicting hospital mortality in adult patients with prolonged stay (>14 days) in surgical } \\
\text { intensive care unit." Minerva Anestesiol 79(8): } 843-852 \text {. }\end{array}$ & \\
\hline $\begin{array}{l}\text { Kim, J., et al. (2009). "Development and validation of the Excess Mortality Ratio-adjusted Injury Severity Score Using } \\
\text { the International Classification of Diseases 10th Edition." Acad Emerg Med 16(5): 454-464. }\end{array}$ & \\
\hline $\begin{array}{l}\text { Muessig, J. M., et al. (2018). "Clinical Frailty Scale (CFS) reliably stratifies octogenarians in German ICUs: a } \\
\text { multicentre prospective cohort study." BMC Geriatr 18(1): } 162 .\end{array}$ & \\
\hline Poor performing tool/score & $\mathrm{N}=5$ \\
\hline $\begin{array}{l}\text { El Maraghi, S., et al. (2016). "Kallistatin level as a novel prognostic marker for community acquired pneumonia (CAP) } \\
\text { in critically ill patients." Intensive Care Medicine Experimental } 4 .\end{array}$ & \\
\hline $\begin{array}{l}\text { Hsin, C. H., et al. (2016). "Venovenous extracorporeal membrane oxygenation in adult respiratory failure: Scores for } \\
\text { mortality prediction." Medicine (Baltimore) 95(25): e3989. }\end{array}$ & \\
\hline $\begin{array}{l}\text { Suberviola, B., et al. (2011). "Prognostic value of proadrenomedullin in severe sepsis and septic shock patients with } \\
\text { community-acquired pneumonia." Critical Care 15: S98 }\end{array}$ & \\
\hline $\begin{array}{l}\text { Suberviola, B., et al. (2013). "Hospital mortality prognostication in sepsis using the new biomarkers suPAR and } \\
\text { proADM in a single determination on ICU admission." Intensive Care Med 39(11): 1945-1952. }\end{array}$ & \\
\hline $\begin{array}{l}\text { Wong, H. R., et al. (2014). "A multibiomarker-based outcome risk stratification model for adult septic shock*." Crit } \\
\text { Care Med 42(4): 781-789. }\end{array}$ & \\
\hline Too small sample size & $\mathrm{N}=2$ \\
\hline $\begin{array}{l}\text { Morton B, Nweze K, O'Connor J, Turton P, Joekes E, Blakey JD, et al. Oxygen exchange and C-reactive protein predict } \\
\text { safe discharge in patients with H1N1 influenza. Qjm. } 2017 \text { Apr 1;110(4):227-32. }\end{array}$ & \\
\hline $\begin{array}{l}\text { Tan L, et al. (2020) "Lymphopaenia predicts disease severity of COVI-19: a descriptive predictive study." Signal } \\
\text { Transduction and Targeted Therpay 5:33 }\end{array}$ & \\
\hline Reviews - Reference list checked & $\mathrm{N}=1$ \\
\hline $\begin{array}{l}\text { Wynants L, et al., (2020) “Prediction models for diagnosis and prognosis of covid-19: systematic review and critical } \\
\text { appraisal”. BMJ 369: m1328. }\end{array}$ & \\
\hline Not in English & $\mathrm{N}=1$ \\
\hline $\begin{array}{l}\text { Piccini, M., et al. (2010) Ethical, deontologic and legal considerations about SIAARTI Document "Clinical ethics } \\
\text { recommendations for the allocation of intensive care treatments, in exceptional, resource-limited circumstances" }\end{array}$ & \\
\hline
\end{tabular}


Supplement 1, Table S1.3 Characteristics of publications informing ICU Triage in pandemic situations. N= 16

\begin{tabular}{|c|c|c|c|c|c|c|c|c|c|c|c|c|}
\hline \multirow[b]{2}{*}{$\begin{array}{c}\text { Author and publication } \\
\text { year }\end{array}$} & \multirow[b]{2}{*}{$\begin{array}{l}\text { Country of } \\
\text { study subjects } \\
\text { or where } \\
\text { guideline } \\
\text { applied }\end{array}$} & \multicolumn{3}{|c|}{ Publication type } & \multicolumn{3}{|c|}{ Target population } & \multicolumn{2}{|c|}{$\begin{array}{l}\text { Pathological } \\
\text { Process }\end{array}$} & \multicolumn{3}{|c|}{$\begin{array}{c}\text { Proposed Benefit } \\
\text { criteria }\end{array}$} \\
\hline & & 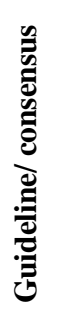 & 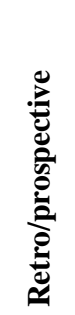 & 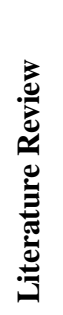 & Age range $(\text { years })^{\alpha}$ & 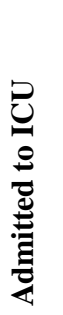 & 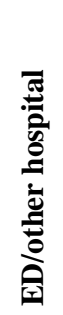 & & 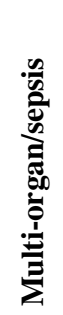 & 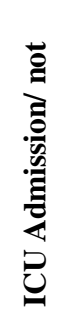 & 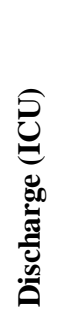 & 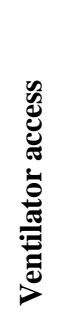 \\
\hline \multicolumn{13}{|l|}{ CONSENSUS } \\
\hline Christian et al., 2006 & Canada & $\checkmark$ & & & 0-paediatric & $\checkmark$ & $\checkmark$ & $\checkmark$ & & $\checkmark$ & $\checkmark$ & \\
\hline Devereaux et al, 2007 & USA & $\checkmark$ & & & All ages & $\checkmark$ & & & & $\checkmark$ & $\checkmark$ & \\
\hline Powell et al., 2008 & USA & $\checkmark$ & & & 0 - older adult & $\checkmark$ & $\checkmark$ & $\checkmark$ & $\checkmark$ & $\checkmark$ & $\checkmark$ & $\checkmark$ \\
\hline White et al., 2009 & USA & $\checkmark$ & & & 12- older adult & & $\checkmark$ & $\checkmark$ & $\checkmark$ & & & $\checkmark$ \\
\hline Wilkens et al., 2010 & USA & $\checkmark$ & & & 0 - older adult & & $\checkmark$ & $\checkmark$ & $\checkmark$ & & & $\checkmark$ \\
\hline $\begin{array}{l}\text { NewYork Taskforce, } \\
2015\end{array}$ & USA & $\checkmark$ & & & 0 - older adult & $\checkmark$ & & $\checkmark$ & $\checkmark$ & $\checkmark$ & $\checkmark$ & $\checkmark$ \\
\hline Chuang et al., 2020 & USA & $\checkmark$ & & & Adults & $\checkmark$ & & & $\checkmark$ & $\checkmark$ & $\checkmark$ & $\checkmark$ \\
\hline \multicolumn{13}{|c|}{ ALGORITHMS/FACTORS } \\
\hline Guest et al, 2009 & UK & & $\mathrm{P}$ & & 60 (IQR 41-69) & $\checkmark$ & & $\checkmark$ & & $\checkmark$ & & \\
\hline Khan et al., 2009 & UK & & $\mathrm{R}$ & & $26-52$ & $\checkmark$ & & & $\checkmark$ & $\checkmark$ & $\checkmark$ & \\
\hline Grissom et al., 2010 & USA & & $\begin{array}{l}\mathrm{R} \\
\mathrm{P}\end{array}$ & & $\begin{array}{l}50 \pm 20 \\
53 \pm 20\end{array}$ & $\checkmark$ & & & $\checkmark$ & & $\checkmark$ & $\checkmark$ \\
\hline Chuang et al, 2020 & USA & & $\mathrm{P}$ & & All ages & $\checkmark$ & & $\checkmark$ & & $\checkmark$ & & $\checkmark$ \\
\hline Adenjil et al., 2011 & UK & & $\mathrm{R}$ & & $18-71$ & $\checkmark$ & & $\checkmark$ & & $\checkmark$ & & \\
\hline Cummings et al., 2020 & USA & & $\mathrm{P}$ & & $62(51-72)$ & $\checkmark$ & & $\checkmark$ & $\checkmark$ & & & \\
\hline
\end{tabular}




\begin{tabular}{|c|c|c|c|c|c|c|c|c|c|c|c|c|}
\hline \multirow[b]{2}{*}{$\begin{array}{c}\text { Author and publication } \\
\text { year }\end{array}$} & \multirow[b]{2}{*}{$\begin{array}{l}\text { Country of } \\
\text { study subjects } \\
\text { or where } \\
\text { guideline } \\
\text { applied }\end{array}$} & \multicolumn{3}{|c|}{ Publication type } & \multicolumn{3}{|c|}{ Target population } & \multicolumn{2}{|c|}{$\begin{array}{c}\text { Pathological } \\
\text { Process }\end{array}$} & \multicolumn{3}{|c|}{$\begin{array}{l}\text { Proposed Benefit } \\
\text { criteria }\end{array}$} \\
\hline & & 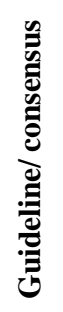 & 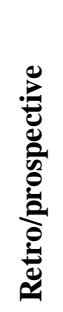 & 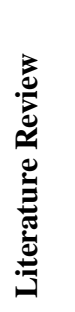 & Age range (years) ${ }^{\alpha}$ & 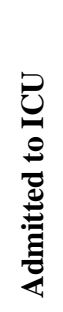 & 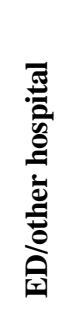 & & 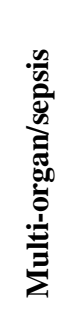 & 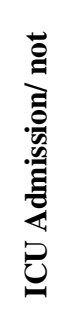 & 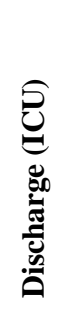 & 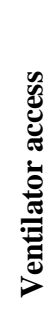 \\
\hline Talmor et al., 2007 & USA & & $\mathrm{R}$ & & Mean $59(\geq 18)$ & & $\checkmark$ & & $\checkmark$ & $\checkmark$ & & $\checkmark$ \\
\hline Liang et al., 2020 & China & & $\mathrm{R}$ & & $48.2 \pm 15.2(4-88)$ & & $\checkmark$ & $\checkmark$ & & $\checkmark$ & & \\
\hline Semple et.al., 2013 & UK & & $\mathrm{R}$ & & 0-older adult & & $\checkmark$ & $\checkmark$ & $\checkmark$ & & & $\checkmark$ \\
\hline Kim et.al., 2012 & USA & & & LR & 0-paediatric & $\checkmark$ & $\checkmark$ & $\checkmark$ & $\checkmark$ & $\checkmark$ & $\checkmark$ & $\checkmark$ \\
\hline
\end{tabular}

${ }^{\alpha}$ range or mean \pm SD or median and IQR as reported in eligibility or findings sections of eligible articles

(D): Derivation cohort; DK=Denmark; LR=Literature review; N/R= Not reported ; SOFA= Sepsis-related Organ Failure Assessment P= Prospective; R=Retrospective; 
Supplement 1, Table S1.4 Characteristics of publications on prognostic tools for risk of death in routine clinical care potentially applicable to ICU triage in pandemics $(\mathrm{N}=46)$

\begin{tabular}{|c|c|c|c|c|c|c|c|c|c|c|c|c|}
\hline \multirow[b]{2}{*}{$\begin{array}{c}\text { Author and } \\
\text { publication year }\end{array}$} & \multirow[b]{2}{*}{$\begin{array}{l}\text { Country of } \\
\text { study } \\
\text { subjects or } \\
\text { where } \\
\text { guideline } \\
\text { applied }\end{array}$} & \multicolumn{3}{|c|}{ Publication type } & \multicolumn{3}{|c|}{ Target population } & \multicolumn{2}{|c|}{$\begin{array}{l}\text { Pathological } \\
\text { Process }\end{array}$} & \multicolumn{3}{|c|}{$\begin{array}{c}\text { Proposed Benefit } \\
\text { criteria }\end{array}$} \\
\hline & & 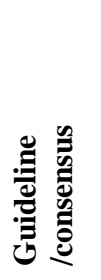 & 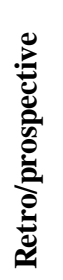 & 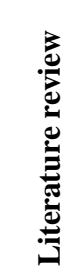 & Age range (years) ${ }^{\alpha}$ & 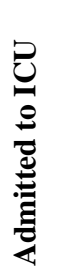 & 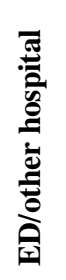 & & 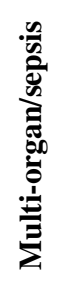 & 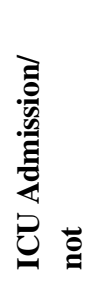 & 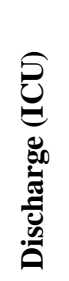 & 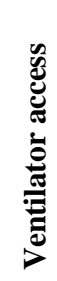 \\
\hline \multicolumn{13}{|l|}{ CONSENSUS } \\
\hline Singer et al., 2016 & Multiple & $\checkmark$ & & & NR & $\checkmark$ & & & $\checkmark$ & $\checkmark$ & & \\
\hline $\begin{array}{l}\text { Daugherty-Biddison et } \\
\text { al, } 2019\end{array}$ & USA & $\checkmark$ & & & All ages & $\checkmark$ & & & $\checkmark$ & $\checkmark$ & & $\checkmark$ \\
\hline Mark et.al., 2016 & USA & & $\mathrm{R}$ & & $\mathrm{N} / \mathrm{R}$ & & $\checkmark$ & $\checkmark$ & $\checkmark$ & $\checkmark$ & & $\checkmark$ \\
\hline \multicolumn{13}{|l|}{ ALGORITHMS } \\
\hline Lim et al., 2003 & $\mathrm{UK}, \mathrm{NZ}, \mathrm{NL}$ & & $\mathrm{P}$ & & $64.1(17-100)$ & & & $\checkmark$ & & $\checkmark$ & & \\
\hline Kellett et al, 2006 & Ireland & & $\mathrm{P}$ & & $62 \pm 20$ & & $\checkmark$ & & $\checkmark$ & $\checkmark$ & $\checkmark$ & \\
\hline Charles et al., 2008 & $\begin{array}{c}\text { Australia, } \\
\text { USA, Canada }\end{array}$ & & $\mathrm{P}$ & & $\geq 18$ & & $\checkmark$ & $\checkmark$ & & $\checkmark$ & & \\
\hline Higgins et al., 2008 & Multiple & & $\mathrm{P}$ & LR & $>18$ & $\checkmark$ & & & $\checkmark$ & & r & \\
\hline Hajjar et al., 2011 & Belgium & & $\mathrm{P}$ & & $61 \pm 2$ & $\checkmark$ & & & $\checkmark$ & $\checkmark$ & $\checkmark$ & \\
\hline Allegretti et al., 2013 & USA & & $\mathrm{P}$ & & older adults & $\checkmark$ & & & $\checkmark$ & $\checkmark$ & $\checkmark$ & \\
\hline Marwick et.al., 2014 & UK & & $\mathrm{P}$ & & $\geq 18$ & & $\checkmark$ & & $\checkmark$ & $\checkmark$ & & \\
\hline $\begin{array}{l}\text { Sprung et.al., } \\
2012\end{array}$ & $\begin{array}{l}\text { Multi-centre } \\
7 \text { Europe }\end{array}$ & & $\mathrm{P}$ & & $59 \pm 18(>18)$ & $\checkmark$ & & & $\checkmark$ & $\checkmark$ & & \\
\hline
\end{tabular}




\begin{tabular}{|c|c|c|c|c|c|c|c|c|c|c|c|c|}
\hline \multirow[b]{2}{*}{$\begin{array}{c}\text { Author and } \\
\text { publication year }\end{array}$} & \multirow[b]{2}{*}{$\begin{array}{l}\text { Country of } \\
\text { study } \\
\text { subjects or } \\
\text { where } \\
\text { guideline } \\
\text { applied }\end{array}$} & \multicolumn{3}{|c|}{ Publication type } & \multicolumn{3}{|c|}{ Target population } & \multicolumn{2}{|c|}{$\begin{array}{l}\text { Pathological } \\
\text { Process }\end{array}$} & \multicolumn{3}{|c|}{$\begin{array}{c}\text { Proposed Benefit } \\
\text { criteria }\end{array}$} \\
\hline & & 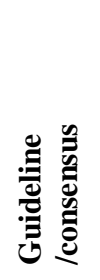 & 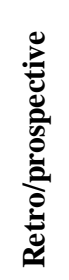 & & Age range (years) ${ }^{\alpha}$ & 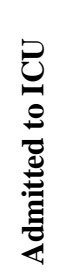 & 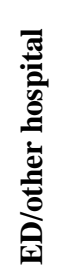 & & 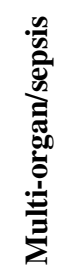 & 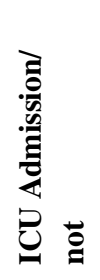 & 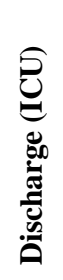 & 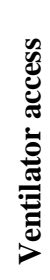 \\
\hline Straede et.al., 2014 & Denmark & & $\mathrm{P}$ & & $62.4 \pm 19.2(\geq 15)$ & & $\checkmark$ & & $\checkmark$ & & & \\
\hline $\begin{array}{l}\text { Dólera-Moreno et al, } \\
2016\end{array}$ & Spain & & $\mathrm{P}$ & & $\begin{array}{l}\text { (D): } 64.4 \pm 16.2 \\
(\mathrm{~V}): 64.6 \pm 16.2\end{array}$ & $\checkmark$ & & & $\checkmark$ & & & \\
\hline Kristensen et.al., 2017 & Denmark & & $\mathrm{P}$ & & $63.8(>16)$ & & $\checkmark$ & & $\checkmark$ & $\checkmark$ & & \\
\hline Bethea et al., 2018 & USA & & $\mathrm{P}$ & & NR & $\checkmark$ & $\checkmark$ & & $\checkmark$ & $\checkmark$ & & \\
\hline Haas et al., 2020 & $\begin{array}{l}\text { Switzerland, } \\
\text { France, USA }\end{array}$ & & $\mathrm{P}$ & & 62 (IQR 46-76) & & $\checkmark$ & & $\checkmark$ & $\checkmark$ & & \\
\hline Heyland 2016 & $\begin{array}{c}\text { Canada \& } \\
\text { USA }\end{array}$ & & $\mathrm{P}$ & & $\geq 80$ years & $\checkmark$ & & & $\checkmark$ & & & \\
\hline Aegerter et al, 2005 & France & & $\mathrm{R}$ & & $\begin{array}{c}56.2+19 \\
\geq 15\end{array}$ & $\checkmark$ & & & $\checkmark$ & $\checkmark$ & & \\
\hline España et al., 2006 & Spain & & $\begin{array}{l}\mathrm{P} \\
\mathrm{R}\end{array}$ & & $\begin{array}{c}64.7+17 \\
(>18)\end{array}$ & & $\checkmark$ & $\checkmark$ & & $\checkmark$ & & \\
\hline Hutchison et al., 2007 & UK & & $\mathrm{R}$ & & Adults & $\checkmark$ & & & $\checkmark$ & $\checkmark$ & $\checkmark$ & \\
\hline Subbe et al., 2010 & UK & & $\mathrm{R}$ & & $65+19$ & & $\checkmark$ & & $\checkmark$ & $\checkmark$ & & \\
\hline O’Sullivan et.al. 2012 & Ireland & & $\mathrm{R}$ & & $56.5(37.2-75.8)$ & & $\checkmark$ & & $\checkmark$ & & & \\
\hline Schuetz et.al., 2013 & USA & & $\mathrm{R}$ & & $65.8 \pm 16.2$ & $\checkmark$ & & & $\checkmark$ & & $\checkmark$ & \\
\hline Yu et al, 2014 & USA & & $\mathrm{R}$ & & $\begin{array}{c}\text { Controls: } \\
64 \text { (IQR 49-78) } \\
\text { Cases: } \\
67 \text { (IQR 55-79) }\end{array}$ & & $\checkmark$ & & $\checkmark$ & $\checkmark$ & & \\
\hline
\end{tabular}




\begin{tabular}{|c|c|c|c|c|c|c|c|c|c|c|c|c|}
\hline \multirow[b]{2}{*}{$\begin{array}{c}\text { Author and } \\
\text { publication year }\end{array}$} & \multirow[b]{2}{*}{$\begin{array}{l}\text { Country of } \\
\text { study } \\
\text { subjects or } \\
\text { where } \\
\text { guideline } \\
\text { applied }\end{array}$} & \multicolumn{3}{|c|}{ Publication type } & \multicolumn{3}{|c|}{ Target population } & \multicolumn{2}{|c|}{$\begin{array}{l}\text { Pathological } \\
\text { Process }\end{array}$} & \multicolumn{3}{|c|}{$\begin{array}{l}\text { Proposed Benefit } \\
\text { criteria }\end{array}$} \\
\hline & & 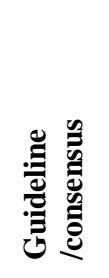 & 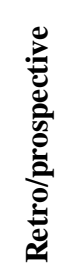 & 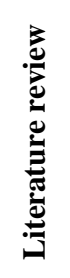 & Age range (years) $)^{\alpha}$ & 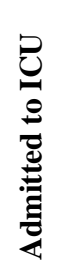 & 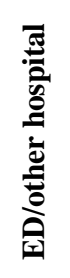 & 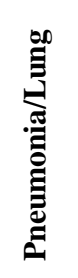 & 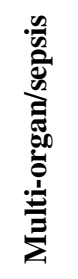 & 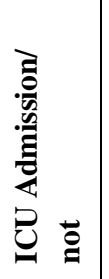 & 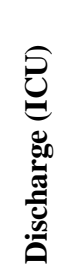 & 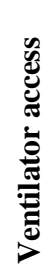 \\
\hline Hough et al., 2015 & USA & & $\mathrm{R}$ & & $54 \pm 17$ & $\checkmark$ & & $\checkmark$ & & & $\checkmark$ & \\
\hline Rosjo et.al., 2015 & Finland & & $\mathrm{N} / \mathrm{R}$ & & $\begin{array}{l}\geq 18 \\
\mathrm{~N} / \mathrm{R}\end{array}$ & $\checkmark$ & & & $\checkmark$ & & & \\
\hline Teubner et.al., 2015 & Australia & & $\mathrm{R}$ & & $62(16-104)$ & & $\checkmark$ & & $\checkmark$ & & & \\
\hline Pannu et al, 2015 & USA & & $\mathrm{R}$ & & $\begin{array}{l}\text { (D): } 61 \text { (IQR 48-72) } \\
\text { (V): } 60 \text { (IQR 49-71) }\end{array}$ & $\checkmark$ & & $\checkmark$ & & & & $\checkmark$ \\
\hline Wallis et al., 2015 & UK & & $\mathrm{R}$ & & $84.3 \pm 5.9$ & & $\checkmark$ & & $\checkmark$ & $\checkmark$ & & \\
\hline Soong et.al., 2017 & UK & & $\mathrm{N} / \mathrm{R}$ & & $>65$ & & $\checkmark$ & & $\checkmark$ & & & \\
\hline Na et.al., 2017 & Korea & & $\mathrm{R}$ & & $69(\geq 18)$ & $\checkmark$ & & & $\checkmark$ & & & $\checkmark$ \\
\hline Jalbout et al., 2017 & USA & & $\mathrm{R}$ & & $\geq 18$ & & $\checkmark$ & & $\checkmark$ & $\checkmark$ & & \\
\hline Granholm et al, 2018 & $\begin{array}{c}\text { Scandinavia, } \\
\text { Germany, NL } \\
\text { France, AUS, } \\
\text { Switzerland, } \\
\text { Spain, Italy, } \\
\text { Brazil, UK, } \\
\text { Canada }\end{array}$ & & $\mathrm{R}$ & & 66 (IQR 55-75) & $\checkmark$ & & & $\checkmark$ & & & \\
\hline Nielsen et.al., 2019 & Denmark & & $\mathrm{R}$ & & $64(\geq 18)$ & $\checkmark$ & & & $\checkmark$ & & & \\
\hline Hartley et al., 2019 & UK & & $\mathrm{R}$ & & NR & $\checkmark$ & & & & $\checkmark$ & $\checkmark$ & $\checkmark$ \\
\hline $\begin{array}{l}\text { Cardona et al, 2018, } \\
2019\end{array}$ & $\begin{array}{l}\text { Australia, } \\
\text { Denmark }\end{array}$ & & $P$ & & $65+$ & $\checkmark$ & $\checkmark$ & & $\checkmark$ & $\checkmark$ & $\checkmark$ & \\
\hline
\end{tabular}




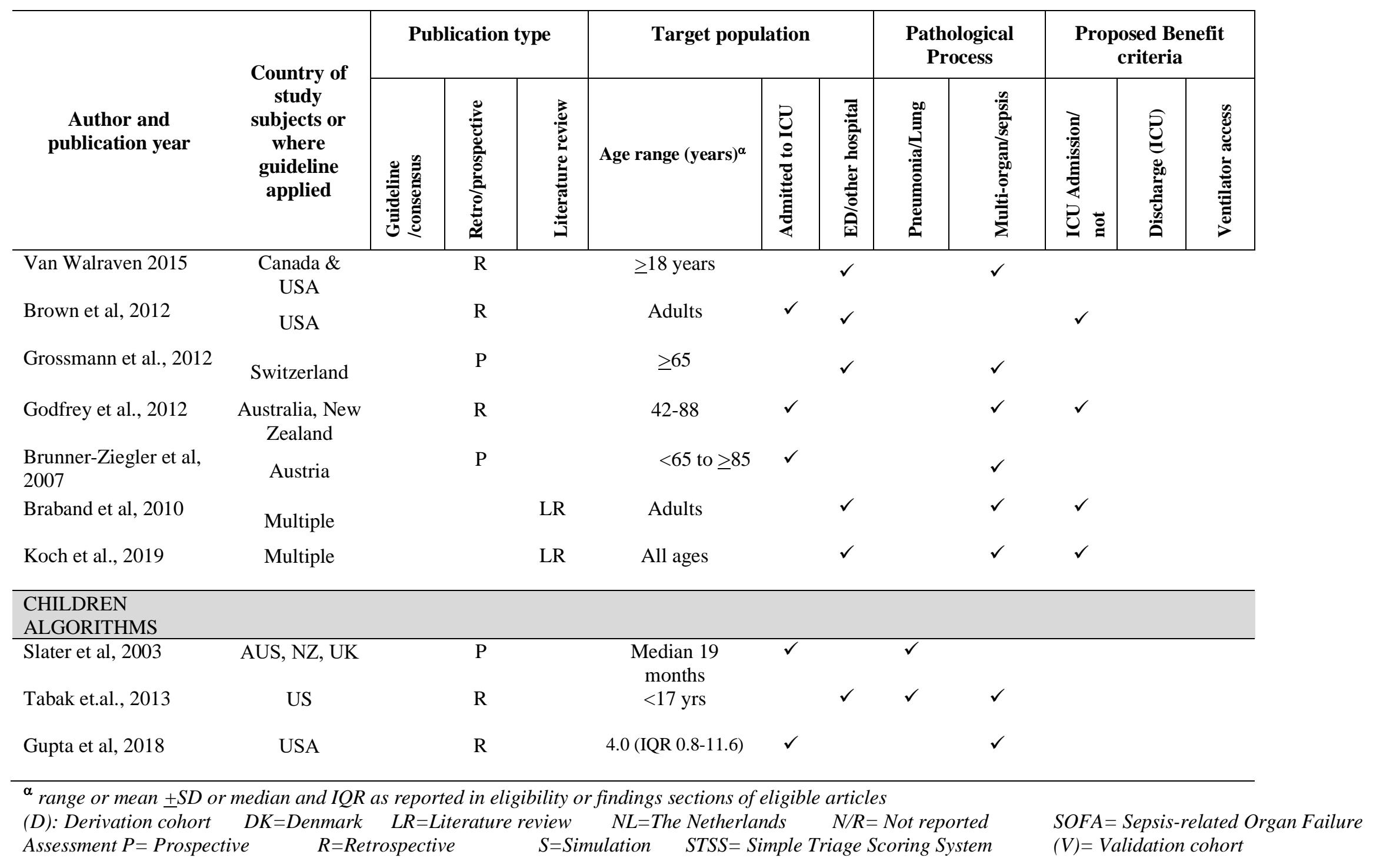


Supplement 2. Table S2.1 Validation status, study types and clinical parameters predicting poor outcome for potentially guidance on ICU admission or discharge during pandemics $(\mathrm{N}=16)$

\begin{tabular}{|c|c|c|c|c|c|c|}
\hline $\begin{array}{l}\text { Objective } \\
\text { parameter } \\
\text { (clinical or } \\
\text { laboratory) }\end{array}$ & 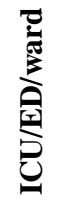 & 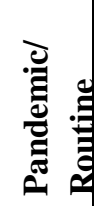 & Study design & 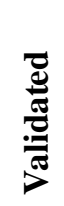 & $\begin{array}{c}\text { Specific parameters / recommended cut-off points } \\
\text { predicting poor outcome }\end{array}$ & $\begin{array}{c}\text { Prognostic performance findings/ thresholds/ } \\
\text { recommendations/ conclusions }\end{array}$ \\
\hline \multicolumn{7}{|c|}{ EXPERT CONSENSUS } \\
\hline SOFA score & I & $\mathrm{P}$ & $\begin{array}{l}\text { Taskforce } \\
\text { advice }\end{array}$ & $\mathrm{N}$ & $\begin{array}{l}\mathrm{PaO} 2 / \mathrm{FiO} 2 \text { ratio } \leq 100 \\
\text { Bilirubin }>12 \mathrm{mg} / \mathrm{dL} \\
\text { Hypotension with vasopressors } \\
\text { (dopamine }>15 \text { epinephrine }>0.1 \text { norepinephrine }>0.1) \\
\text { Glasgow Coma score }<6 \\
\text { Creatinine }(\mathrm{mg} / \mathrm{dL}(\mu \mathrm{mol} / \mathrm{L})>5.0 \text { or urine }<200 \mathrm{~mL} / \mathrm{d}\end{array}$ & $\begin{array}{l}\text { Exclusion from critical care: } \\
\text { 1.If risk of hospital mortality }>=80 \% \\
\text { SOFA }>15 \\
\text { SOFA }>5 \text { for }>=5 \mathrm{~d} \text {, and with flat or rising trend } \\
>=6 \text { organ failures } \\
\text { 2. Severe, chronic disease with short life expectancy (age }>85 \mathrm{yr} \text { ) } \\
\text { [Devereaux 2007] } \\
\text { Exclusion from ICU } \\
\text { SOFA }>11 \text { Blue code=High probability of mortality; should be discharged } \\
\text { from critical care; medical management palliate and discharge } \\
\text { [Powell 2008] } \\
\text { Exclusion from ventilator access: } \\
\text {-Cardiac arrest: unwitnessed, non-responsive, recurrent } \\
\text {-Metastatic malignancy with poor prognosis } \\
\text {-End-stage organ failure (cardiac, pulmonary, hepatic, renal or } \\
\text { neurological) [Powell 2008] }\end{array}$ \\
\hline SOFA score & I & $\mathrm{P}$ & $\begin{array}{l}\text { Collaborative } \\
\text { process using } \\
\text { best evidence, } \\
\text { expert panels, } \\
\text { stakeholder } \\
\text { consultations } \\
\text { and ethical } \\
\text { principles }\end{array}$ & $\mathrm{N}$ & $\begin{array}{l}\text { Inclusion criteria: The patient must have } 1 \text { of the following: } \\
\text { A. Requirement for invasive ventilatory support } \\
\text { - Refractory hypoxemia ( } \mathrm{SpO} 2<90 \% \text { on non-rebreather } \\
\text { mask or FIO2 }>0.85 \text { ) } \\
\text { - Respiratory acidosis }(\mathrm{pH}<7.2) \\
\text { - Clinical evidence of impending respiratory failure } \\
\text { - Inability to protect or maintain airway } \\
\text { B. Hypotension (systolic blood pressure }<90 \mathrm{~mm} \mathrm{Hg} \text { or } \\
\text { relative hypotension) with clinical evidence of shock } \\
\text { - altered level of consciousness, } \\
\text { - decreased urine output or other evidence of end-organ failure } \\
\text { refractory to volume resuscitation requiring } \\
\text { vasopressor or inotrope support that cannot be } \\
\text { managed in ward setting }\end{array}$ & $\begin{array}{l}\text { The minimum criteria for survival dictate reassessment at } 48 \text { and } 120 \\
\text { hours, as well as an ongoing cut-off ceiling if a patient ever has a SOFA } \\
\text { score of } 11 \text { or higher or any other exclusion criteria. } \\
\text { Highest priority for ICU: SOFA score }<=7 \text { or single-organ failure } \\
\text { Exclusion criteria- Manage on ward May not require ICU if too healthy } \\
\text { and no evidence of organ failure or can be managed on the ward } \\
\text { [Christian 2006] }\end{array}$ \\
\hline
\end{tabular}




\begin{tabular}{|c|c|c|c|c|c|c|}
\hline $\begin{array}{l}\text { Objective } \\
\text { parameter } \\
\text { (clinical or } \\
\text { laboratory) }\end{array}$ & 氞 & 异 & Study design & 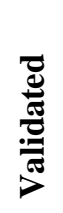 & $\begin{array}{c}\text { Specific parameters / recommended cut-off points } \\
\text { predicting poor outcome }\end{array}$ & $\begin{array}{l}\text { Prognostic performance findings/ thresholds/ } \\
\text { recommendations/ conclusions }\end{array}$ \\
\hline $\begin{array}{l}\text { Triage } \\
\text { protocol }\end{array}$ & I & $\mathrm{P}$ & $\begin{array}{l}\text { Qualitative } \\
\text { consultation }\end{array}$ & & 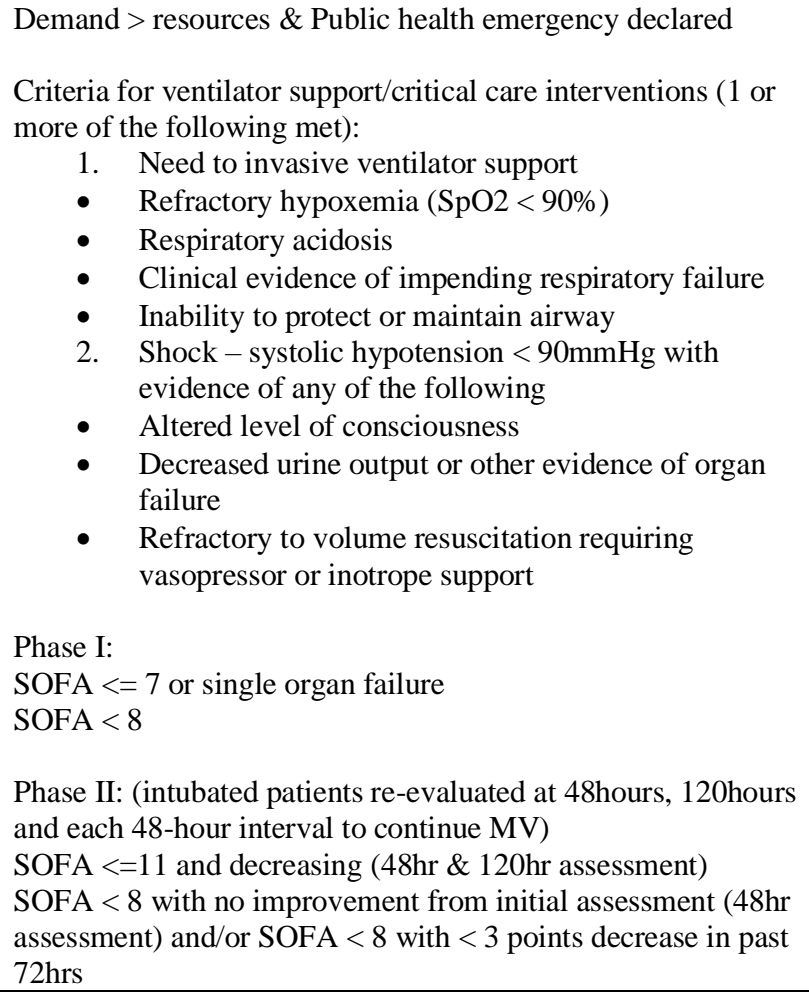 & $\begin{array}{l}\text { Highest priority for ventilator or critical care bed } \\
\text { Immediate priority for ventilator or critical care bed } \\
\text { Highest priority to continue with ventilator or critical care bed } \\
\text { Immediate priority to continue with ventilator or critical care bed } \\
\text { [Chuang 2020] }\end{array}$ \\
\hline $\begin{array}{l}\text { Ventilator } \\
\text { allocation } \\
\text { during public } \\
\text { SOFA score }\end{array}$ & $\mathrm{E}$ & $\mathrm{P}$ & Expert opinion & $\mathrm{N}$ & $\begin{array}{l}\text { SOFA score } \\
\text { Comorbidities } \\
\text { Life cycle principle (Age, or prioritise the young; i.e. save the } \\
\text { most years) }\end{array}$ & $\begin{array}{l}\text { Decline offer of ventilator and other scarce ICU technologies: } \\
\text { SOFA score >12, severe comorbidities, death likely within } 1 \text { year, age } \geq 75 \\
\text { years } \\
\text { Highest priority for ICU and ventilator: } \\
\text { SOFA score < 6, no conditions that limit long-term survival, age } 12-40 \\
\text { Next priority: } \\
\text { SOFA score 6-9, minor comorbid conditions with small impact on long- } \\
\text { term survival, age 41-60 [White 2009] }\end{array}$ \\
\hline
\end{tabular}




\begin{tabular}{|c|c|c|c|c|c|c|}
\hline $\begin{array}{l}\text { Objective } \\
\text { parameter } \\
\text { (clinical or } \\
\text { laboratory) }\end{array}$ & 氞 & 异 & Study design & 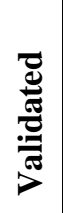 & $\begin{array}{c}\text { Specific parameters / recommended cut-off points } \\
\text { predicting poor outcome }\end{array}$ & $\begin{array}{l}\text { Prognostic performance findings/ thresholds/ } \\
\text { recommendations/ conclusions }\end{array}$ \\
\hline $\begin{array}{l}\text { AGILITIES } \\
\text { score } \\
\text { Triage system } \\
\text { for ventilators }\end{array}$ & I & $\mathrm{P}$ & $\begin{array}{l}\text { Consensus by } \\
\text { authors after } \\
\text { Retrospective } \\
\text { analysis and }\end{array}$ & $\mathrm{N}$ & $\begin{array}{l}\text { Medical /surgical history: } 1 \text { pt for each of stroke, coronary } \\
\text { disease, immune disease, diabetes, COPD, asthma, } \\
\text { drug/alcohol use, smoking; } 2 \text { pts each for heart surgery, }>10 \\
\text { medicines, home oxygen, CPAP/BiPAP; } 4 \text { pts for dialysis. } \\
\text { Age in years x } 0.5 \text { (or } 24 \text { minus months of life for toddlers) } \\
\text { Glasgow score } 15 \text { minus GCS } \\
\text { Infusions: \# IV drugs x } 2 \\
\text { Lungs: } 2 \text { pts for use of suction; } 3 \text { pts each for SpO } 2<88 \% \text { on } \\
50 \% \text { O2, PAP }>30 \mathrm{~cm} \text { of water, respiratory rate }>30 \text {. } \\
\text { Interventions: } 1 \text { pt for every IV drug started } \\
\text { Tests: } 1 \text { pt for every test in the past } 6 \text { hours } \\
\text { Incidental: } 3 \text { pt for every Lt/fluid in past } 6 \text { hours; } 10 \text { pts for } \\
\quad \text { threat or violence to any provider } \\
\text { Excessive weight: } 3 \text { pts for BMI }>30 ; 6 \text { pts for BMI }>40 \\
\text { Subtract } 2 \text { pts if gestation }>34 \text { weeks }\end{array}$ & $\begin{array}{l}\text { AGILITIES score used to remove ambiguity of ventilator allocation: } \\
\text { score }>100 \text { is an indication for removal from ventilator and seek other } \\
\text { means of ventilation (i.e. bag mask) but may preserve airway devices such } \\
\text { as endotracheal tube. [Wilkens 2010] }\end{array}$ \\
\hline $\begin{array}{l}\text { NY Dept of } \\
\text { Health } 2015 \\
\text { Guidelines }\end{array}$ & $\mathrm{E}$ & $\mathrm{P}$ & $\begin{array}{l}\text { Consensus } \\
\text { guidelines }\end{array}$ & & $\begin{array}{l}\text { Worst-Moderate and Best parameters specified for adults, } \\
\text { children and neonates with (blue or black, red, yellow, green) } \\
\text { colour scheme adopted from military disaster protocols for } \\
\text { admission eligibility \& exclusion criteria for ventilator } \\
\text { allocation }\end{array}$ & $\begin{array}{l}\text { Exclusion from ventilator } \\
\text { Medical Conditions that Result in Immediate or Near-Immediate Mortality } \\
\text { Even with Aggressive Therapy } \\
\text { - Cardiac arrest: unwitnessed arrest, recurrent arrest without hemodynamic } \\
\text { stability, arrest unresponsive to standard interventions and measures; } \\
\text { trauma-related arrest } \\
\text { - Irreversible age-specific hypotension [NY Taskforce 2015] }\end{array}$ \\
\hline \multicolumn{7}{|c|}{ ALGORITHM/TRIAGE PROTOCOLS } \\
\hline $\begin{array}{l}\text { COVID-19 } \\
\text { clinical risk } \\
\quad \text { score }\end{array}$ & $\mathrm{E}$ & $\mathrm{P}$ & Retrospective & $\mathrm{Y}$ & $\begin{array}{l}\text { Increased age, per year in patients with COVID-19 } \\
\text { Any chest X-ray abnormality in patients with COVID-19 } \\
\text { Presence of hemoptysis in patients with COVID-19 } \\
\text { Presence of dyspnea in patients with COVID-19 } \\
\text { Unconsciousness in patients with COVID-19 } \\
\text { Positive cancer history in patients with COVID-19 }\end{array}$ & $\begin{array}{l}\text { Predicts critical illness event, i.e. composite outcome of wither } \\
\text { requiring ventilation, ICU admission, or death in patients with } \\
\text { COVID-19 } \\
\text { OR } 1.03 \text { (95\% CI } 1.01-1.05), \mathrm{p}=0.002 \\
\text { OR } 3.39 \text { (95\% CI } 2.14-5.38), \mathrm{p}<0.001 \\
\text { OR } 4.53 \text { (95\% CI } 1.36-15.15), \mathrm{p}=0.01 \\
\text { OR } 1.88 \text { (95\% CI } 1.18-3.01), \mathrm{p}=0.01 \\
\text { OR } 4.71(95 \% \text { CI } 1.39-15.98), \mathrm{p}=0.01 \\
\text { OR } 4.07(95 \% \text { CI } 1.23-13.43), \mathrm{p}=0.02 \\
\text { [Liang 2020] }\end{array}$ \\
\hline
\end{tabular}




\begin{tabular}{|c|c|c|c|c|c|c|}
\hline $\begin{array}{l}\text { Objective } \\
\text { parameter } \\
\text { (clinical or } \\
\text { laboratory) }\end{array}$ & 空 & 导 & Study design & 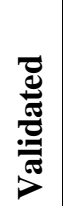 & $\begin{array}{c}\text { Specific parameters / recommended cut-off points } \\
\text { predicting poor outcome }\end{array}$ & $\begin{array}{l}\text { Prognostic performance findings/ thresholds/ } \\
\text { recommendations/ conclusions }\end{array}$ \\
\hline $\begin{array}{l}\text { Algorithm } \\
\text { for COVID- } \\
19 \text { in- } \\
\text { hospital } \\
\text { mortality }\end{array}$ & I & $\mathrm{P}$ & Prospective & $\mathrm{N}$ & $\begin{array}{l}\text { Age (per } 10 \text {-year increase) } \\
\text { Chronic cardiac disease (CHF, CAD) } \\
\text { COPD or interstitial lung disease } \\
\text { Interleukin } 6 \text { (per decile increase) } \\
\text { D-dimer per decile increase }\end{array}$ & $\begin{array}{l}\text { Predictors of in-hospital mortality: } \\
\text { HR } 1.31(1.09-1.57) \\
\text { HR } 1.76(1.08-2.86) \\
\text { HR } 2.94(1.48-5.84) \\
\text { HR } 1.11(1.02-1.20) \\
\text { HR } 1.10(1.01-1.19) \\
\text { [Cummings 2020] }\end{array}$ \\
\hline SOFA score & $\mathrm{I}$ & $\mathrm{P}$ & $\begin{array}{l}\text { Observational } \\
\text { cohort study }\end{array}$ & $\mathrm{Y}$ & $\begin{array}{l}\text { Criteria for assessing patients before ICU admission: } \\
\text { Triage for critical care } \\
\text { 1) Patient has any of the predefined exclusion criteria, or has a } \\
\text { SOFA score > } 11 \text { (Considered too ill for ICU support; manage } \\
\text { medically \& palliative care as needed) } \\
\text { 2) SOFA 8-11 (Intermediate priority; admit to ICU if no } \\
\text { patient in red category requires bed) } \\
\text { 3) SOFA score <=7 or single-organ failure (Highest priority; } \\
\text { admit to ICU if bed available) } \\
\text { 4) No significant organ failure (i.e. does not require any } \\
\text { ICU specific treatment and care can be managed adequately on } \\
\text { general ward) (Defer or discharge Reassess as needed) }\end{array}$ & $\begin{array}{l}\text { Performance of priority for ICU admission: } \\
\text { Sensitivity } 61.0 \% \text { and specificity } 87.0 \% \\
\text { But AUROC for SOFA score }>11 \text { at admission predicting mortality in all } \\
\text { patients AUROC }=0.740 \text { indicating only a fair level of test accuracy. } \\
\text { [Guest 2009] }\end{array}$ \\
\hline SOFA score & $\mathrm{I}$ & $P$ & $\begin{array}{l}\text { Retrospective } \\
\text { validation } \\
\text { Retrospective } \\
\text { chart review }\end{array}$ & $\mathrm{N}$ & $\begin{array}{l}\mathrm{PaO} 2 / \mathrm{FiO} 2 \text { ratio } \leq 100 \\
\text { Bilirubin }>12 \mathrm{mg} / \mathrm{dL} \\
\text { Hypotension with vasopressors } \\
\text { (dopamine }>15 \text { epinephrine }>0.1 \text { norepinephrine }>0.1) \\
\text { Glasgow Coma score }<6 \\
\text { Creatinine }(\mathrm{mg} / \mathrm{dL}(\mu \mathrm{mol} / \mathrm{L})>5.0 \text { or urine }<200 \mathrm{~mL} / \mathrm{d}\end{array}$ & $\begin{array}{l}\text { Ongoing assessment of SOFA scores not improving at } 48 \text { hours in } \\
\text { mechanically ventilated patients led to changes in decision to remain in } \\
\text { ICU [Khan 2009] } \\
\text { For discharge from ICU as not likely to benefit: SOFA > } 11 \text { [Grissom } \\
\text { 2010] }\end{array}$ \\
\hline $\begin{array}{l}\text { Modified } \\
\text { SOFA score }\end{array}$ & I & $P$ & $\begin{array}{l}\text { Retrospective } \\
\text { validation }\end{array}$ & $\mathrm{Y}$ & $\begin{array}{l}\mathrm{PaO} 2 / \mathrm{FiO} 2 \text { ratio } \leq 150 \\
\text { Bilirubin }- \text { Scleral icterus or jaundice } \\
\text { Hypotension with vasopressors } \\
\text { (dopamine }>15 \text { epinephrine }>0.1 \text { norepinephrine }>0.1) \\
\text { Glasgow Coma score }<6 \\
\text { Creatinine }(\mathrm{mg} / \mathrm{dL}(\mu \mathrm{mol} / \mathrm{L})>5.0\end{array}$ & $\begin{array}{l}\text { For discharge from ICU as not likely to benefit: high risk SOFA score } \\
\text { combined with comorbid conditions that increase mortality risk } \\
\text { [Grissom 2010] }\end{array}$ \\
\hline
\end{tabular}




\begin{tabular}{|c|c|c|c|c|c|c|}
\hline $\begin{array}{l}\text { Objective } \\
\text { parameter } \\
\text { (clinical or } \\
\text { laboratory) }\end{array}$ & 氙 & 异 & Study design & 胥 & $\begin{array}{l}\text { Specific parameters / recommended cut-off points } \\
\text { predicting poor outcome }\end{array}$ & $\begin{array}{l}\text { Prognostic performance findings/ thresholds/ } \\
\text { recommendations/ conclusions }\end{array}$ \\
\hline $\begin{array}{c}\text { STSS Score } \\
\text { (Simple } \\
\text { Triage } \\
\text { Scoring }\end{array}$ & I & $\mathrm{P}$ & $\begin{array}{l}\text { Retrospective } \\
\text { analysis }\end{array}$ & $\mathrm{Y}$ & $\begin{array}{l}\text { The STSS uses vital signs and patient characteristics that are } \\
\text { available at initial presentation. } \\
\text { Its components are: } \\
\text { Respiratory rate }>30 \text { breaths per minute (OR 3.9, CI 2.5-6.3) } \\
\text { Shock index }>1 \text { (HR > BP) (OR 2.8, CI 1.8-4.2) } \\
\text { Low oxygen saturation (OR 2.8, CI 1.8-4.2) } \\
\text { Altered mental status (OR 1.9, CI 1.3-2.8) } \\
\text { Age of } 65 \text { to } 74 \text { years (OR 3.0, CI 1.7-5.5) } \\
\text { Age of at least } 75 \text { years (OR 4.4, CI 2.7-7.2) } \\
\text { *simplified final rule points = } 1 \text { for each variable }\end{array}$ & $\begin{array}{l}\text { A higher STSS score equates with higher mortality in comparison with a } \\
\text { high SOFA score. } \\
\text { The performance of the STSS score was better at predicting need for ICU } \\
\text { admission (AUROC } 0.88 ; 0.78 \text { to } 0.98 \text { ) and need for } \\
\text { MV (AUROC } 0.91 ; 0.83 \text { to } 0.99 \text { ), compared to the SOFA score in } \\
\text { predicting the need for admission to the ICU (AUROC } 0.77 ; 0.65 \text { to } 0.89 \text { ) } \\
\text { and the requirement for MV (AUROC } 0.87 ; 0.72 \text { to } 1.00 \text { ). [Adeniji } 2011 \text { ] }\end{array}$ \\
\hline $\begin{array}{l}\text { Epidemic } \\
\text { Triage rule }\end{array}$ & $\mathrm{E}$ & $\mathrm{P}$ & $\begin{array}{l}\text { Retrospective } \\
\text { validation }\end{array}$ & $\mathrm{Y}$ & $\begin{array}{l}\text { (1 point each for) age of } 65 \mathrm{yrs}-74 \text { or age } \geq 75 \\
\text { Altered mental status } \\
\text { Respiratory rate of } 30 \text { breaths } / \mathrm{min} \\
\text { Low oxygen saturation } \\
\text { Shock index of }>1.0 \text { (heart rate }>\text { blood pressure) }\end{array}$ & $\begin{array}{l}\text { Score } \geq 3 \text { Predicts need for critical care, mechanical ventilators and in- } \\
\text { hospital death } \\
\text { AUROC (derivation) } 0.80 \text { for mortality, } 0.70 \text { for ICU admission, } 0.69 \text { for } \\
\text { MV requirement } \\
\text { AUROC (validation) } 0.73 \text { for mortality, } 0.70 \text { for ICU admission, } 0.68 \text { for } \\
\text { MV requirement [Talmor 2007] }\end{array}$ \\
\hline
\end{tabular}




\begin{tabular}{|c|c|c|c|c|c|c|c|c|c|c|c|}
\hline $\begin{array}{c}\text { Objective } \\
\text { parameter } \\
\text { (clinical or } \\
\text { laboratory) }\end{array}$ & & 异 & Study design & 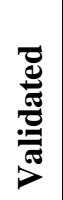 & \multicolumn{6}{|c|}{$\begin{array}{c}\text { Specific parameters / recommended cut-off points } \\
\text { predicting poor outcome }\end{array}$} & $\begin{array}{l}\text { Prognostic performance findings/ thresholds/ } \\
\text { recommendations/ conclusions }\end{array}$ \\
\hline $\begin{array}{l}\text { PELOD score } \\
\text { for ventilator } \\
\text { triage } \\
\text { protocol }\end{array}$ & $\mathrm{E}$ & $\mathrm{P}$ & $\begin{array}{l}\text { Literature } \\
\text { review }\end{array}$ & $\mathrm{Y}$ & $\begin{array}{cc}\text { Exclusion } \\
\text { - } & \text { Cardi } \\
& \text { cardia } \\
& \text { cardia } \\
\text { - } & \text { Metas } \\
\text { - } & \text { Advar } \\
\text { - } & \text { Sever } \\
& \text { highly } \\
-\quad \text { End s } \\
\text { failure } \\
\text { chron } \\
\text { PaO2 } \\
\text { previc } \\
\text { with I } \\
\text { pulmo } \\
\text { PELoo scorin }\end{array}$ & 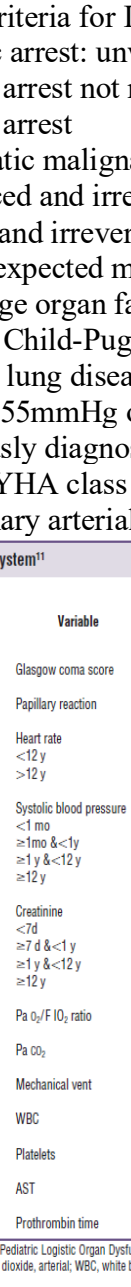 & $\begin{array}{l}\text { U: } \\
\text { tnessed } \\
\text { ponsiv } \\
\text { t diseas } \\
\text { rsible } \\
\text { ble neu } \\
\text { tality } \\
\text { ure of a } \\
\text { score } 7 \\
\text { with F } \\
\text { second } \\
\text { d prima } \\
\text { I or IV } \\
\text { ressure } \\
\end{array}$ & $\begin{array}{l}\text { cardiac } \\
\text { to elec } \\
\text { with p } \\
\text { amunoc } \\
\text { logic e } \\
\text { y: NYY } \\
\text { r MEL } \\
\text { V1<2. } \\
\text { y pulm } \\
\text { y pulm } \\
\text { eart fai } \\
50 \mathrm{~mm} \\
\end{array}$ & $\begin{array}{l}\text { Irest, v } \\
\text { ical th } \\
\text { or pros } \\
\text { ompron } \\
\text { ent or } \\
\text { A Clas } \\
\text { score } \\
\text { predic } \\
\text { onary h } \\
\text { nary hy } \\
\text { ure, or } \\
\text { Ig }\end{array}$ & 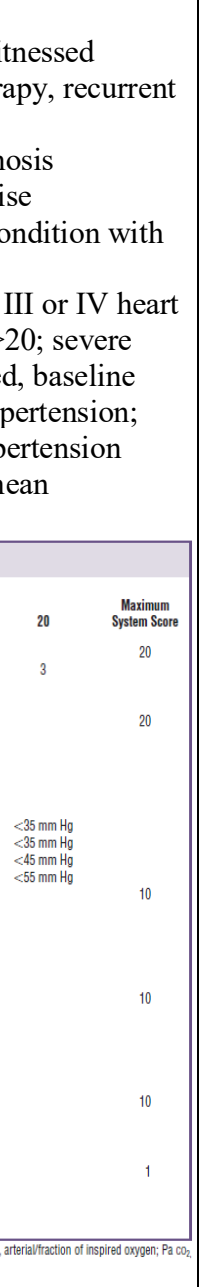 & $\begin{array}{l}\text { Highest priority for ICU: } \\
\text { Initial assessment PELOD }<21 \text { or single organ failure; } 48 \mathrm{~h} \text { assessment } \\
\text { PELOD <33 and decreasing; } 120 \mathrm{~h} \text { assessment PELOD }<33 \text { and decreasing } \\
\text { progressively } \\
\text { Mortality of PELOD }<2120 \% \\
\text { Intermediate priority for ICU: } \\
\text { Initial assessment PELOD } 21-33 \text {; } 48 \mathrm{~h} \text { assessment PELOD }<21 \text { no change; } \\
\text { 120h assessment PELOD }<21 \text { minimal decrease ( }<3 \text { point decrease in past } \\
72 \mathrm{~h} \text { ) } \\
\text { Mortality of PELOD } 3390.6 \% \\
\text { Exclusion from ICU: } \\
\text { Any exclusion criteria or PELOD }>33 \\
\text { PELOD score system proposed for use as a ventilator triage tool for } \\
\text { pediatric patients during a respiratory pandemic. }\end{array}$ \\
\hline
\end{tabular}




\begin{tabular}{|c|c|c|c|c|c|c|}
\hline $\begin{array}{c}\text { Objective } \\
\text { parameter } \\
\text { (clinical or } \\
\text { laboratory) }\end{array}$ & 氙 & 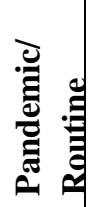 & Study design & 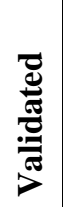 & $\begin{array}{l}\text { Specific parameters / recommended cut-off points } \\
\text { predicting poor outcome }\end{array}$ & $\begin{array}{l}\text { Prognostic performance findings/ thresholds/ } \\
\text { recommendations/ conclusions }\end{array}$ \\
\hline $\begin{array}{l}\text { Community } \\
\text { Assessment } \\
\text { Tools (CATs) } \\
\text { criteria }\end{array}$ & $\mathrm{W}$ & $\mathrm{P}$ & Retrospective & $\mathrm{N}$ & $\begin{array}{l}\text { CATS parameters } \\
\text { Severe respiratory distress } \\
\text { Increased respiratory rate } \\
\text { Oxygen saturation } \leq 92 \% \text { on pulse oximetry breathing air, or } \\
\text { 'on oxygen' } \\
\text { Respiratory exhaustion } \\
\text { Evidence of severe clinical dehydration or clinical shock } \\
\text { Altered consciousness level } \\
\text { Causing other clinical concern to patient's GP or clinical team }\end{array}$ & 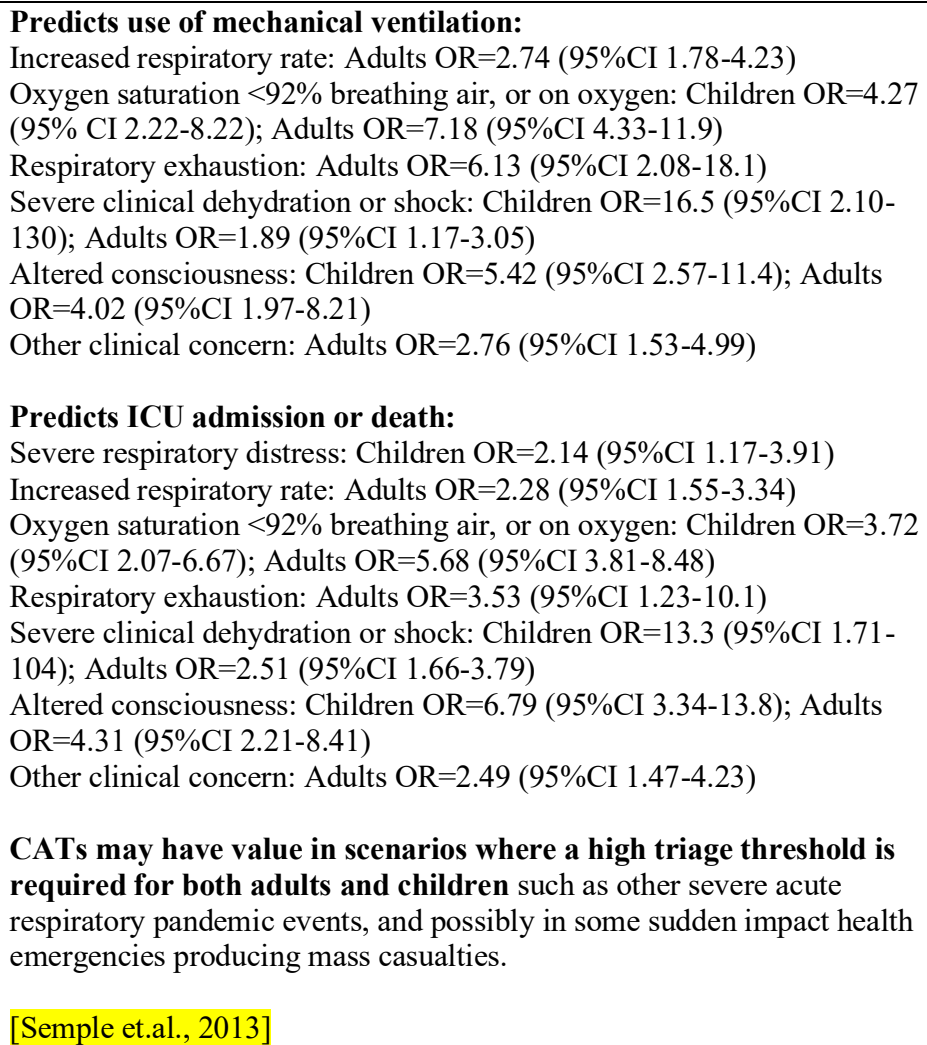 \\
\hline
\end{tabular}


Supplement 2. Table S2.2 Validation status, and clinical parameters predicting poor outcome for potentially guidance on ICU admission or discharge derived from routine care studies in ICU, ED or wards(N= 46 studies)

\begin{tabular}{|c|c|c|c|c|c|c|}
\hline $\begin{array}{l}\text { Objective } \\
\text { parameter } \\
\text { (clinical or } \\
\text { laboratory) }\end{array}$ & 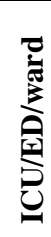 & 异总 & Study design & 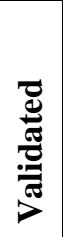 & $\begin{array}{c}\text { Specific parameters / recommended cut-off points } \\
\text { predicting poor outcome }\end{array}$ & $\begin{array}{l}\text { Prognostic performance findings/ thresholds/ } \\
\text { recommendations/ conclusions }\end{array}$ \\
\hline \multicolumn{7}{|c|}{ EXPERT CONSENSUS } \\
\hline $\begin{array}{l}\text { Triaging } \\
\text { scoring } \\
\text { system }\end{array}$ & I & $\mathrm{R}$ & $\begin{array}{l}\text { Consensus } \\
\text { Framework }\end{array}$ & & $\begin{array}{l}\text { **Scoring system } \\
\text { Primary considerations: } \\
\text { Prognosis for short-term survival - based on Adults (SOFA) or } \\
\text { paediatrics (PELOD-2) } \\
\text { PELOD-2 } \\
\text { Glasgow coma score >=11 } \\
\text { Pupillary reaction - both reactive } \\
\text { Lactatemia (mmol/L) }<5.0 \\
\text { Mean arterial pressure (mmHg) } \\
\text { Creatinine (umol/L) } \\
\text { PaO2 (mmH)/FiO2 >=61 } \\
\text { PaCO2 (mmHg) >=58 Invasive ventilation - no } \\
\text { WBC count (x10^9/L) >2 Platelet (x10^9/L) >=142 } \\
\text { Prognosis for long-term survival - based on assessment of } \\
\text { comorbid conditions: } \\
\text { 1. NYHA class IV heart failure. } \\
\text { 2. Advanced lung disease with FEV1 }<25 \% \text { predicted, total } \\
\text { lung capacity }<60 \% \text { predicted, or baseline PAO2 }<55 \text { mm } \\
\text { Hg. } \\
\text { 3. Primary pulmonary hypertension with NYHA class III or IV } \\
\text { heart failure. } \\
\text { 4. Chronic liver disease with Child-Pugh score }>7 \text {. } \\
\text { 5. Severe trauma. } \\
\text { 6. Advanced untreatable neuromuscular disease. } \\
\text { 7. Metastatic malignant disease or high-grade primary } \\
\text { brain tumors } \\
\text { Secondary considerations (tiebreaker): Age (life cycle } \\
\text { considerations) }\end{array}$ & $\begin{array}{l}\text { Score 1: SOFA score }<=8, \text { PELOD-2 }<=12 \\
\text { Score 2: SOFA score 9-11, } 12 \text { PELOD-2 12-13 } \\
\text { Score 3: SOFA score 12-14, PELOD-2 14-16 } \\
\text { Score 4: SOFA score }>14 \text {, PELOD-2 }>=17 \\
\text { Score } \geq 3 \text { : severe comorbid conditions; death likely within 1year } \\
\text { Score 1: Age 0-49years } \\
\text { Score 2: Age 50-69years } \\
\text { Score 3: Age 70-84years } \\
\text { Score 4: Age >=85years } \\
\text { [Daugherty- Biddison 2019] }\end{array}$ \\
\hline
\end{tabular}




\begin{tabular}{|c|c|c|c|c|c|c|}
\hline $\begin{array}{l}\text { Objective } \\
\text { parameter } \\
\text { (clinical or } \\
\text { laboratory) }\end{array}$ & 己ِ & 兽 & Study design & 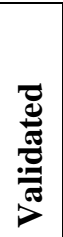 & $\begin{array}{c}\text { Specific parameters / recommended cut-off points } \\
\text { predicting poor outcome }\end{array}$ & $\begin{array}{l}\text { Prognostic performance findings/ thresholds/ } \\
\text { recommendations/ conclusions }\end{array}$ \\
\hline qSOFA & $\mathrm{E}$ & $\mathrm{R}$ & $\begin{array}{l}\text { 3rd } \\
\text { International } \\
\text { Consensus } \\
\text { Definitions for } \\
\text { Sepsis \& } \\
\text { Retrospective }\end{array}$ & $\mathrm{N}$ & $\begin{array}{l}\text { Quick sepsis-related multiorgan failure assessment for } \\
\text { pneumonia patients } \\
\text { one point each for low blood pressure ( } \mathrm{SBP} \leq 100 \mathrm{mmHg} \text { ), high } \\
\text { respiratory rate }(\geq 22 \text { breaths per min), or altered mental state } \\
\text { (Glasgow coma scale }<15 \text { ) } \\
\\
\text { Sepsis-3 (suspected infection }+ \text { qSOFA } \geq 2 \text { ) } \\
\text { vasopressors required to maintain } \mathrm{MAP} \geq 65 \mathrm{~mm} \mathrm{Hg} \\
\text { AND serum lactate level }>2 \mathrm{mmol} / \mathrm{L} \rightarrow \text { septic shock }\end{array}$ & $\begin{array}{l}\text { Predictor of: } \\
\text { ICU admission (OR } 4.6995 \% \text { CI } 3.21-6.84, \mathrm{p}<0.0001) \\
\text { need for invasive ventilation (OR } 3.62(95 \% \text { CI } 2.33-5.62, \mathrm{p}<0.0001) \\
\text { in-hospital mortality (OR } 3.62(95 \% \text { CI } 1.83-7.19, \mathrm{p} 0.001) \\
\text { [Mark 2016] } \\
\text { qSOFA in sepsis predicts in-hospital mortality of } 10 \% \\
\text { qSOFA in septic shock predicts mortality of } 40 \% \text { [Singer \&Cliff 2016] }\end{array}$ \\
\hline $\begin{array}{l}\text { modified } \\
\text { British } \\
\text { Thoracic } \\
\text { Society } \\
\text { (mBTS) rule }\end{array}$ & $\mathrm{W}$ & $\mathrm{R}$ & Consensus & $\mathrm{Y}$ & $\begin{array}{l}\text { One point for each of Confusion, Urea }>7 \mathrm{mmol} / \mathrm{l} \text {, Respiratory } \\
\text { rate }>30 / \mathrm{min} \text {, low systolic }(<90 \mathrm{~mm} \mathrm{Hg}) \text { or diastolic }(<60 \mathrm{~mm} \\
\mathrm{Hg}) \text { Blood pressure) when blood urea results not available. }(2+ \\
\text { points=severe pneumonia) }\end{array}$ & $\begin{array}{l}\text { CURB score } \geq 2 \text { has OR=5.2 95\%CI 2.7-10.3 30-day mortality } \\
\text { Sensitivity } 75 \% \text { (95\% CI } 72 \text {-78) and specificity } 69 \% \text { (95\% CI } 66 \text { - 72) } \\
\text { [Lim WS 2003] } \\
\text { Albumin }<30 \mathrm{~g} / \mathrm{dl} \text { OR } 4.795 \% \text { CI } 2.5-8.7 \text { [Lim WS 2003] }\end{array}$ \\
\hline \multicolumn{7}{|c|}{ ALGORITHM/SCORES } \\
\hline \multicolumn{7}{|c|}{ INTENSIVE CARE } \\
\hline $\begin{array}{l}\text { Prediction } \\
\text { tool for } \\
\text { favourable } \\
\text { neurologic } \\
\text { outcome } \\
\text { among } \\
\text { paediatric } \\
\text { ICU patients }\end{array}$ & I & $\mathrm{R}$ & Retrospective & $\mathrm{Y}$ & $\begin{array}{l}\text { Cardiac arrest - no versus yes } \\
\text { Days of mechanical ventilation (for every } 3 \text { day decrease) }\end{array}$ & $\begin{array}{l}\text { Predicts favourable neurological outcome (defined as improvement, no } \\
\text { change, or decline by only } 1 \text { in Pediatric Cerebral Performance Category } \\
\text { scale, from ICU admission to ICU discharge) } \\
\text { OR 0.50 (95\% CI 0.41-0.61), p }<0.001 \\
\text { OR 0.91 (95\% CI 0.89-0.93), p }<0.001 \\
\text { [Gupta 2018] }\end{array}$ \\
\hline
\end{tabular}




\begin{tabular}{|c|c|c|c|c|c|c|}
\hline $\begin{array}{l}\text { Objective } \\
\text { parameter } \\
\text { (clinical or } \\
\text { laboratory) }\end{array}$ & 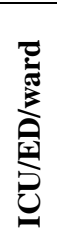 & 导 & Study design & 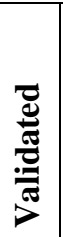 & $\begin{array}{c}\text { Specific parameters / recommended cut-off points } \\
\text { predicting poor outcome }\end{array}$ & $\begin{array}{l}\text { Prognostic performance findings/ thresholds/ } \\
\text { recommendations/ conclusions }\end{array}$ \\
\hline $\begin{array}{l}\text { Simplified } \\
\text { Mortality } \\
\text { Score for the } \\
\text { Intensive } \\
\text { Care Unit } \\
\text { (SMS-ICU) }\end{array}$ & I & $\mathrm{R}$ & Retrospective & $\mathrm{Y}$ & $\begin{array}{l}\text { Age } \\
\text { - } 60-79 \text { years }-10 \text { points } \\
-\geq 80 \text { years }-13 \text { points } \\
\text { Lowest systolic blood pressure } \\
-\leq 49 \mathrm{mmHg}-6 \text { points } \\
-50-69 \mathrm{mmHg}-5 \text { points } \\
\text { Acute surgical admission }-3 \text { points } \\
\text { Haematologic malignancy or metastatic cancer }-7 \text { points } \\
\text { Use of vasopressors/inotropes }-4 \text { points } \\
\text { Use of respiratory support }-5 \text { points } \\
\text { Use of renal replacement therapy }-4 \text { points }\end{array}$ & $\begin{array}{l}\text { Predicts 90-day mortality in patients admitted to ICU } \\
\text { AUROC } 0.72 \text { (95\% CI 0.71-0.74) } \\
\text { Haematologic malignancy or metastatic cancer - OR } 2.68 \text { (95\% CI } 2.19- \\
3.28), \mathrm{p}<0.001 \\
\text { Use of vasopressors or inotropes - OR } 1.76 \text { (95\% CI 1.48-2.09), p < } 0.001 \\
\text { Use of respiratory support - OR } 1.99 \text { (95\% CI } 1.69-2.34), \mathrm{p}<0.001 \\
\text { [Granholm 2018] }\end{array}$ \\
\hline $\begin{array}{l}\text { Predictive } \\
\text { model of ICU } \\
\text { mortality }\end{array}$ & I & $\mathrm{R}$ & Prospective & $\mathrm{Y}$ & $\begin{array}{l}\text { Sepsis } \\
\text { Mechanical ventilation } \\
\text { Inotropic support } \\
\text { Cardiology admission (including surgical cardiology } \\
\text { admissions) }\end{array}$ & $\begin{array}{l}\text { Predicts all-cause mortality during ICU admission } \\
\text { OR }=4.41 \text { (95\% CI 2.01-9.68), } \mathrm{p}<0.001 \\
\text { OR }=9.99(95 \% \text { CI 4.54-22.02), } \mathrm{p}<0.001 \\
\text { OR }=5.01(95 \% \text { CI } 2.35-10.70), \mathrm{p}<0.001 \\
\text { OR }=2.84(95 \% \text { CI } 1.19-6.81), \mathrm{p}=0.019 \\
\text { AUROC } 0.95 \text { (95\% CI 0.91-0.99) in validation sample } \\
\text { [Dólera-Moreno 2016] }\end{array}$ \\
\hline $\begin{array}{l}\text { Revised } \\
\text { Paediatric } \\
\text { Index of } \\
\text { Mortality } \\
\text { (PIM2) }\end{array}$ & I & $\mathrm{R}$ & Retrospective & $\mathrm{Y}$ & $\begin{array}{l}\text { Paediatric Revised index } \\
\text { Mechanical ventilation predicts mortality: } \\
\text { High risk diagnosis (cardiac arrest preceding ICU admission, } \\
\text { severe combined immune deficiency, leukaemia or lymphoma } \\
\text { after first induction, spontaneous cerebral haemorrhage, } \\
\text { cardiomyopathy or myocarditis, hypoplastic left heart } \\
\text { syndrome, HIV infection, liver failure as main reason for ICU } \\
\text { admission, or, neurodegenerative disorder) }\end{array}$ & $\begin{array}{l}\text { OR } 3.801(95 \% \text { CI } 3.061-4.719), \mathrm{p}<0.001 \text { predicts ICU mortality } \\
\text { OR } 5.381(95 \% \text { CI } 4.566-6.343), \mathrm{p}<0.001 \text { predicts ICU mortality } \\
\text { AUROC } 0.85 \text { (95\% CI 0.82-0.87) in patients admitted with cardiac illness } \\
\text { AUROC } 0.85 \text { (95\% CI 0.82-0.89) in patients admitted with neurological } \\
\text { illness } \\
\text { AUROC } 0.87 \text { (95\% CI 0.84-0.89) in patients admitted with respiratory } \\
\text { illness } \\
\text { [Slater 2003] }\end{array}$ \\
\hline
\end{tabular}




\begin{tabular}{|c|c|c|c|c|c|c|}
\hline $\begin{array}{l}\text { Objective } \\
\text { parameter } \\
\text { (clinical or } \\
\text { laboratory) }\end{array}$ & 氞 & 异 & Study design & 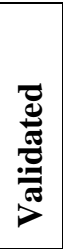 & $\begin{array}{l}\text { Specific parameters / recommended cut-off points } \\
\text { predicting poor outcome }\end{array}$ & $\begin{array}{l}\text { Prognostic performance findings/ thresholds/ } \\
\text { recommendations/ conclusions }\end{array}$ \\
\hline $\begin{array}{l}\text { Severe } \\
\text { Hypoxaemia } \\
\text { Associated } \\
\text { Risk } \\
\text { Prediction } \\
\text { Model for } \\
\text { mechanically } \\
\text { ventilated } \\
\text { patients in } \\
\text { ICU }\end{array}$ & I & $\mathrm{R}$ & Retrospective & $\mathrm{Y}$ & $\begin{array}{l}\text { Serum } \mathrm{pH} 7.2-7.35 \\
\text { Serum } \mathrm{pH}<7.2 \\
\text { Vasopressor use (dopamine, epinephrine, vasopressin, and } \\
\text { phenylephrine) }\end{array}$ & $\begin{array}{l}\text { Predicts in hospital mortality for patients with severe hypoxaemic } \\
\text { respiratory failure on mechanical ventilation } \\
\mathrm{OR}=2.2(95 \% \text { CI } 1.3-3.6), \mathrm{p}=0.002 \\
\mathrm{OR}=17.4(95 \% \text { CI } 4.7-112.7), \mathrm{p}<0.001 \\
\mathrm{OR}=2.1(95 \% \text { CI } 1.2-3.6), \mathrm{p}=0.006 \\
\text { Derivation cohort AUC } 0.85(95 \% \text { CI } 0.81-0.89) \\
\text { Validation cohort AUC } 0.80 \text { (95\% CI } 0.76-0.83) \\
\text { [Pannu 2015] }\end{array}$ \\
\hline $\begin{array}{l}\text { ProVent } 14 \\
\text { score }\end{array}$ & I & $\mathrm{R}$ & Cohort & $\mathrm{Y}$ & $\begin{array}{l}\text { Increasing age (continuous) } \\
\text { Platelet count }<100,000 / \mathrm{mL} \\
\text { Requirement for vasopressors/inotropes still on day } 14 \\
\text { Requirement for hemodialysis (renal replacement therapy } \\
\text { provided on or within } 48 \text { hours before or after day } 14 \text { of } \\
\text { mechanical ventilation) } \\
\text { Non-trauma admission. }\end{array}$ & $\begin{array}{l}\text { For patients already received } 14 \text { days of mechanical ventilation: } \\
\text { AUROC for 1-year mortality model using continuous variables was } \\
0.80 \text { (95\% CI } 0.76-0.83) \text { development cohort and } \\
0.78 \text { ( } 95 \% \text { CI } 0.72-0.83) \text { validation cohort } \\
\text { vs. APACHE III for 1-yr mortality in this cohort } 0.60(95 \% \text { CI, } 0.55-0.64) \\
\text { ProVent } 14 \text { model can support clinical judgment of prognosis and can } \\
\text { inform clinical decision aids to facilitate discussions of goals of care in the } \\
\text { setting of prolonged mechanical ventilation (Potential to use for } \\
\text { discharge from ICU) [Hough } 2015 \text { ] }\end{array}$ \\
\hline $\begin{array}{l}\text { SAPSII } \\
\& \text { source of } \\
\text { ICU } \\
\text { admission }\end{array}$ & I & $\mathrm{R}$ & $\begin{array}{l}\text { Observational } \\
\text { study }\end{array}$ & & $\begin{array}{l}\text { Age-excluded SAPS-II score has a greater impact on ICU } \\
\text { mortality } \\
\text { ICU admission from within hospital vs. from a public place }\end{array}$ & $\begin{array}{l}\text { OR }=1.0395 \% \text { CI } 1.02-1.03 p<0.001 \\
\text { OR }=1.5, p=0.04 \\
{[\text { Brunner-Ziegler 2007 }]}\end{array}$ \\
\hline
\end{tabular}




\begin{tabular}{|c|c|c|c|c|c|c|}
\hline $\begin{array}{l}\text { Objective } \\
\text { parameter } \\
\text { (clinical or } \\
\text { laboratory) }\end{array}$ & 気 & 异 & Study design & 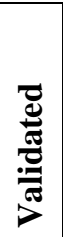 & $\begin{array}{c}\text { Specific parameters / recommended cut-off points } \\
\text { predicting poor outcome }\end{array}$ & $\begin{array}{l}\text { Prognostic performance findings/ thresholds/ } \\
\text { recommendations/ conclusions }\end{array}$ \\
\hline $\begin{array}{l}\text { SAPS II } \\
\text { (Simplified } \\
\text { Acute } \\
\text { Physiology } \\
\text { Score II) }\end{array}$ & $\mathrm{I}$ & $\mathrm{R}$ & $\begin{array}{l}\text { Retrospective } \\
\text { analysis }\end{array}$ & $\mathrm{Y}$ & $\begin{array}{l}\text { SAPS II } \\
\text { Age }>50 \text {; } \\
\text { heart rate }<69 \text { or }>120 \text {; } \\
\text { Systolic } \mathrm{BP}<100 \text { or }>200 \text {; } \\
\text { Temperature }>39 \mathrm{C} \text {; } \\
\mathrm{PaO} 2 \text { if on } \mathrm{MV}:<100,100-199 \text { or }>200 \text {; } \\
\text { urinary output }<1.0 \mathrm{~L} / \text { day; } \\
\text { Blood urea Nitrogen }>10 \mathrm{mmol} / \mathrm{L} \text {; } \\
\text { WBC }<1 \text { or }>20 / \mathrm{mm} 3 \text {; } \\
\text { Potassium }<3 \text { or }>5 \mathrm{mmol} / \mathrm{L} \text {; } \\
\text { Sodium }<125 \text { or }>145 \text {; } \\
\text { Bicarbonate }<20 \mathrm{mmol} / \mathrm{L} \text {; } \\
\text { Bilirubin }>68.4 \text { umol/L; } \\
\text { Glasgow Comma Scale }<14 \text {; } \\
\text { metastatic cancer; } \\
\text { scheduled medical admission; unscheduled surgical admission }\end{array}$ & $\begin{array}{l}\text { SAPS II score range from } 0 \text { to } 163 \text { points; The higher the score the higher } \\
\text { the mortality risk. } \\
\quad 64 \text { points } 75 \% \text { in-hospital mortality; } \\
\quad 77 \text { points } 90 \% \text { mortality; } \\
\quad \geq 142=100 \% \text { mortality } \\
\text { AUROC } 0.87 \text { for in-hospital mortality among ICU patients } \\
\text { [Aegerter } 2005 \text { ] }\end{array}$ \\
\hline $\begin{array}{l}\text { SMART- } \\
\text { COP score }\end{array}$ & I & $\mathrm{R}$ & Cohort & $\mathrm{Y}$ & $\begin{array}{l}\text { Systolic blood pressure }<90 \mathrm{~mm} \mathrm{Hg} \\
\text { Multilobar involvement on radiography } \\
\text { Albumin }<3.5 \mathrm{mg} / \mathrm{dL} \\
\text { Respiratory rate }>30 \text { breaths/min (age }>50 \text { years) or } \\
\text { RR }>25 \text { breaths } / \text { min if }<50 \text { years } \\
\text { Tachycardia } \geq 125 \mathrm{bpm} \\
\text { Confusion (new onset) } \\
\text { Oxygen saturation } \mathrm{PaO} 2 \leq 93 \% \text { ( }<50 \text { years), } \leq 90 \% \text { ( } \geq 50 \text { years) } \\
\text { P Arterial } \mathrm{pH}<7.35 \text { (decreased) }\end{array}$ & $\begin{array}{l}92.3 \% \text { (84.8-96.9) sensitive in identifying which patients need ICU- } \\
\text { level care (Intensive vasopressor and respiratory support=IVRS) and } \\
\text { 30-day mortality. Specificity } 62.3 \text { (58.8-65.7) } \\
\text { Score 5-6 points :High risk ( } 1 \text { in } 3 \text { ) of needing IRVS } \\
\text { Score } \geq 7 \text { points: Very high risk }(2 \text { in } 3 \text { ) of needing IRVS } \\
\text { Score } \geq 3 \text { AUROC } 0.87 \text { ( } 95 \% \text { CI } 0.83-0.91) ; \text { Score } \geq 2 \text { AUROC } 0.80 \\
(95 \% \text { CI } 0.76-0.84) \text { [Charles } 2008]\end{array}$ \\
\hline $\begin{array}{l}\text { MPM } \\
\text { Mortality } \\
\text { Probability } \\
\text { Models }\end{array}$ & I & $\mathrm{R}$ & Cohort & $\mathrm{Y}$ & $\begin{array}{l}\text { Age } 70+\text {; heart rate } \geq 150 \mathrm{bpm} \text {; systolic } \mathrm{BP} \leq 90 \mathrm{mmHg} \text {; on } \\
\text { mechanical ventilation; Coma/stupor or GCS } 3-4 \text {; Chronic } \\
\text { renal failure; acute renal failure; Cirrhosis; metastatic } \\
\text { neoplasm; unscheduled admission; CPR prior to admission; GI } \\
\text { bleeding; cerebrovascular incident; cardiac dysrrhythmia; full } \\
\text { code status; or no other risk factor. }\end{array}$ & $\begin{array}{l}\text { AUROC } 0.837 \text { on admission and } 0.844 \text { at } 24 \text { hours in predicting hospital } \\
\text { mortality. Reasonable to support clinical judgment. Robust to predict ICU } \\
\text { outcome in groups of patients meeting risk factor profiles. } \\
\text { [Higgins 2008] }\end{array}$ \\
\hline
\end{tabular}




\begin{tabular}{|c|c|c|c|c|c|c|}
\hline $\begin{array}{l}\text { Objective } \\
\text { parameter } \\
\text { (clinical or } \\
\text { laboratory) }\end{array}$ & 己ِ & 总 & Study design & 总 & $\begin{array}{c}\text { Specific parameters / recommended cut-off points } \\
\text { predicting poor outcome }\end{array}$ & $\begin{array}{l}\text { Prognostic performance findings/ thresholds/ } \\
\text { recommendations/ conclusions }\end{array}$ \\
\hline $\begin{array}{l}\text { Algorithm at } \\
\text { ICU } \\
\text { Admission }\end{array}$ & I & $\mathrm{R}$ & $\begin{array}{l}\text { Retrospective } \\
\text { analysis }\end{array}$ & $\mathrm{Y}$ & $\begin{array}{l}\text { APACHE III-j scoring system to predict risk of death. } \\
\text { Treatment limitations at admission to ICU vs risk of death } \\
\text { Sepsis with shock } \\
\text { Unspecified respiratory diseases } \\
\text { Chronic comorbidities }\end{array}$ & $\begin{array}{l}\text { OR }=5.68,95 \% \text { CI } 5.32 \%-6.07 \%(\mathrm{p}<0.001) \\
\text { OR }=0.53,95 \% \text { CI } 0.37-0.76(\mathrm{p}<0.001) \\
\text { OR }=0.57,95 \% \text { CI } 0.38-0.85(\mathrm{p}=.005) \\
\text { OR }=0.89,95 \% \text { CI } 0.81-0.98(\mathrm{p}=0.019) \\
\text { AUROC }=0.80 \text { Development model }(2007 \text { and 2008) } \\
\text { AUROC }=0.79 \text { Validation model }(2009) \\
{[\text { Godfrey } 2012]}\end{array}$ \\
\hline $\begin{array}{l}\text { Intensive } \\
\text { Care } \\
\text { Admission } \\
\text { Triage scores }\end{array}$ & I & $\mathrm{R}$ & $\begin{array}{c}\text { Prospective } \\
\text { observational }\end{array}$ & $\mathrm{N}$ & $\begin{array}{l}\text { Final triage score parameters: } \\
\text { Age: } 60-70 \text { (32 pts); 70-80 (53pts); }>80 \text { (56pts) } \\
\text { Diagnosis: cerebrovascular accident (83pts); intracerebral } \\
\text { haemorrhage/haematoma (19pts); status post-cardiopulmonary } \\
\text { resuscitation }(27 \mathrm{pts}) ; \text { cardiogenic shock (94pts) } \\
\text { Creatinine: } 140-200 \text { (8pts); }>200 \text { (13pts) } \\
\text { WCC: } \leq 5 \text { (17pts); }>21 \text { (12pts) } \\
\text { Platelets: } \leq 70 \text { (53pts); 70-120 (24pts) } \\
\text { Albumin: } \leq 24 \text { (15pts) } \\
\text { Vasopressors: any (24pts) } \\
\text { Glasgow Coma scale: } \leq 4 \text { (117pts); 5-6 (78pts); 7-14 (7pts) } \\
\text { Karnofsky performance status: } \leq 40 \%(42 \mathrm{pts}) ; 50-60 \%(16 \mathrm{pts}) \\
\text { Operative status: no operation (12pts) } \\
\text { Chronic disorders: chronic renal failure, dialysis, cirrhosis } \\
\text { (29pts); haematologic neoplasm, metastatic cancer, AIDS, } \\
\text { immunosuppression (25pts) }\end{array}$ & $\begin{array}{l}\text { Admission criteria: } \\
\text { Initial refusal score }<173.5 \text { (predicted to survive) and subsequent } \\
\text { assessment with final triage score }>0 \text {. Final triage score AUROC } 0.83 \\
(95 \% \text { CI } 0.80-0.86 \text { ) } \\
\text { Non-admission criteria: } \\
\text { Initial refusal score }>173.5 \text { (predicted to not survive), or initial refusal } \\
\text { score }<173.5 \text { with final triage score }=0 \text { (survive even without ICU care) } \\
\text { This objective triage score can improve patient survival, decrease } \\
\text { admissions of patients who will not benefit from ICU care. } \\
\text { [Sprung et.al., 2012] }\end{array}$ \\
\hline qSOFA & I & $\mathrm{R}$ & Retrospective & $\mathrm{N}$ & Sepsis-3: suspected infection + qSOFA $\geq 2$ & $\begin{array}{l}\text { qSOFA } \geq 2 \text { predicts: } \\
\text { 28-day mortality: } \mathrm{OR}=2.722 \text { (95\% CI } 1.582-4.683), \mathrm{p}<0.001 \\
\text { Worse clinical severity (septic shock) and medical resource use } \\
\text { (ventilators+ haemodialysis) within } 72 \mathrm{~h} \text { of } \mathrm{ICU} \text { admission. } \\
\text { [Na et.al., 2017] }\end{array}$ \\
\hline
\end{tabular}




\begin{tabular}{|c|c|c|c|c|c|c|}
\hline $\begin{array}{c}\text { Objective } \\
\text { parameter } \\
\text { (clinical or } \\
\text { laboratory) }\end{array}$ & 氕 & 异苛 & Study design & 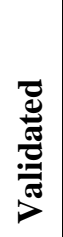 & $\begin{array}{c}\text { Specific parameters / recommended cut-off points } \\
\text { predicting poor outcome }\end{array}$ & $\begin{array}{l}\text { Prognostic performance findings/ thresholds/ } \\
\text { recommendations/ conclusions }\end{array}$ \\
\hline $\begin{array}{l}\text { Aggregation } \\
\text { of long-term } \\
\text { disease } \\
\text { history and } \\
\text { acute } \\
\text { physiology } \\
\text { (SAPS II, } \\
\text { APACHE II) }\end{array}$ & $\mathrm{I}$ & $\mathrm{R}$ & Retrospective & $\mathrm{Y}$ & $\begin{array}{l}\text { Aggregated history parameters: } \\
\text { Age, sex, } 10 \text {-year disease history prior to ICU, length of } \\
\text { hospital stay, transfer category, hospital code, acute (first } 24 \mathrm{~h} \\
\text { ICU admission) SAPS II \& APACHE II score } \\
\text { SAPS II parameters: } \\
\text { Age, bilirubin, FiO2, Glasgow coma scale, heart frequency, } \\
\text { PaO2, serum bicarbonate, serum potassium, sodium, urea, } \\
\text { systolic blood pressure, temperature, urine output, white cell } \\
\text { count, chronic disease (metastatic cancers, haematological } \\
\text { malignancy, AIDs), mechanical ventilation, type of admission } \\
\text { APACHE II parameters: } \\
\text { Age, arterial pH, Glasgow coma scale, heart rate, haematocrit, } \\
\text { mean arterial pressure, PaO2, respiratory rate, serum creatinine, } \\
\text { potassium, sodium, temperature, white cell count, acute renal } \\
\text { failure, history of severe organ failure of immunocompromise } \\
\text { (cardiac failure, cirrhosis, chronic lung disease, dialysis- } \\
\text { dependent renal failure) }\end{array}$ & $\begin{array}{l}\text { Aggregated history predicts: } \\
\text { In-hospital mortality: AUROC } 0.792 \text {, PPV } 0.575 \\
\text { 30-day mortality: AUROC } 0.787 \text {, PPV } 0.481 \\
\text { 90-day mortality: AUROC } 0.787 \text {, PPV } 0.589 \\
\\
\text { [Nielsen et.al., 2019] }\end{array}$ \\
\hline $\begin{array}{l}\text { Secretoneurin } \\
\text { levels }\end{array}$ & I & $\mathrm{R}$ & $\mathrm{N} / \mathrm{R}$ & $\mathrm{Y}$ & $\begin{array}{l}\text { Secretoneurin levels }>175 \mathrm{pmol} / \mathrm{L} \text { associated with mortality in } \\
\text { critically ill patients with severe sepsis }\end{array}$ & $\begin{array}{l}\text { Predict in-hospital mortality for patients with severe sepsis: } \\
\text { OR=3.17 (95\% CI 1.12-9.00), } \mathrm{p}=0.030 \\
\text { Predict shock during hospitalisation for patients with severe sepsis: } \\
\text { OR=2.17 ( } 95 \% \text { CI 1.06-4.46), } \mathrm{p}=0.034 \\
\text { [Rosjo et.al., 2015] }\end{array}$ \\
\hline $\begin{array}{l}\text { Palliative } \\
\text { Performance } \\
\text { Scale }\end{array}$ & I & $\mathrm{R}$ & Prospective & Y & $\begin{array}{l}\text { Primary diagnosis of emergency CABG or valve replacement } \\
\text { Male } \\
\text { APACHE II (per } 9 \text { points) } \\
\text { Charlson Comorbidity Index (per } 2 \text { points) } \\
\text { Primary diagnosis of stroke } \\
\text { Clinical frailty scale (per } 2 \text { points) }\end{array}$ & $\begin{array}{l}\text { Predict poor performance at } 12 \text { months } \\
\text { OR } 8.48 \text { ( } 95 \% \text { CI } 1.91-37.8) \\
\text { Predict good performance at } 12 \text { months } \\
\text { OR } 0.51 \text { (95\%CI } 0.29-0.89) \\
\text { OR } 0.52(95 \% \text { CI } 0.37-0.74) \\
\text { OR } 0.59(95 \% \text { CI } 0.43-0.80) \\
\text { OR } 0.30(95 \% \text { CI } 0.09-0.96) \\
\text { OR } 0.42(95 \% \text { CI } 0.25-0.71) \\
\text { Cut-off @10\% probability of PPS }>=60 \text { : Sensitivity } 97 \% \text {, specificity } 32 \% \\
\text { Cut-off @ } 50 \% \text { probability of PPS }>=60 \text { : Sensitivity } 47 \% \text {, specificity } 92 \% \\
\text { AUROC } 0.81 \text { fir } 8 \text {-parameter model } \\
\text { [Heyland et al., 2016] }\end{array}$ \\
\hline
\end{tabular}




\begin{tabular}{|c|c|c|c|c|c|c|}
\hline $\begin{array}{l}\text { Objective } \\
\text { parameter } \\
\text { (clinical or } \\
\text { laboratory) }\end{array}$ & 己 & 兽 & Study design & 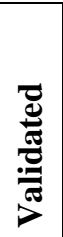 & $\begin{array}{c}\text { Specific parameters / recommended cut-off points } \\
\text { predicting poor outcome }\end{array}$ & $\begin{array}{l}\text { Prognostic performance findings/ thresholds/ } \\
\text { recommendations/ conclusions }\end{array}$ \\
\hline Procalcitonin & I & $\mathrm{R}$ & Retrospective & $\mathrm{Y}$ & $\begin{array}{l}\text { Plasma procalcitonin } 72 \mathrm{~h} \text { change } 4 \text { category cut-offs: } \\
0 \% \text { decrease or PCT increase } \\
40 \% \text { decrease } \\
60 \% \text { decrease } \\
\geq 80 \% \text { decrease }\end{array}$ & 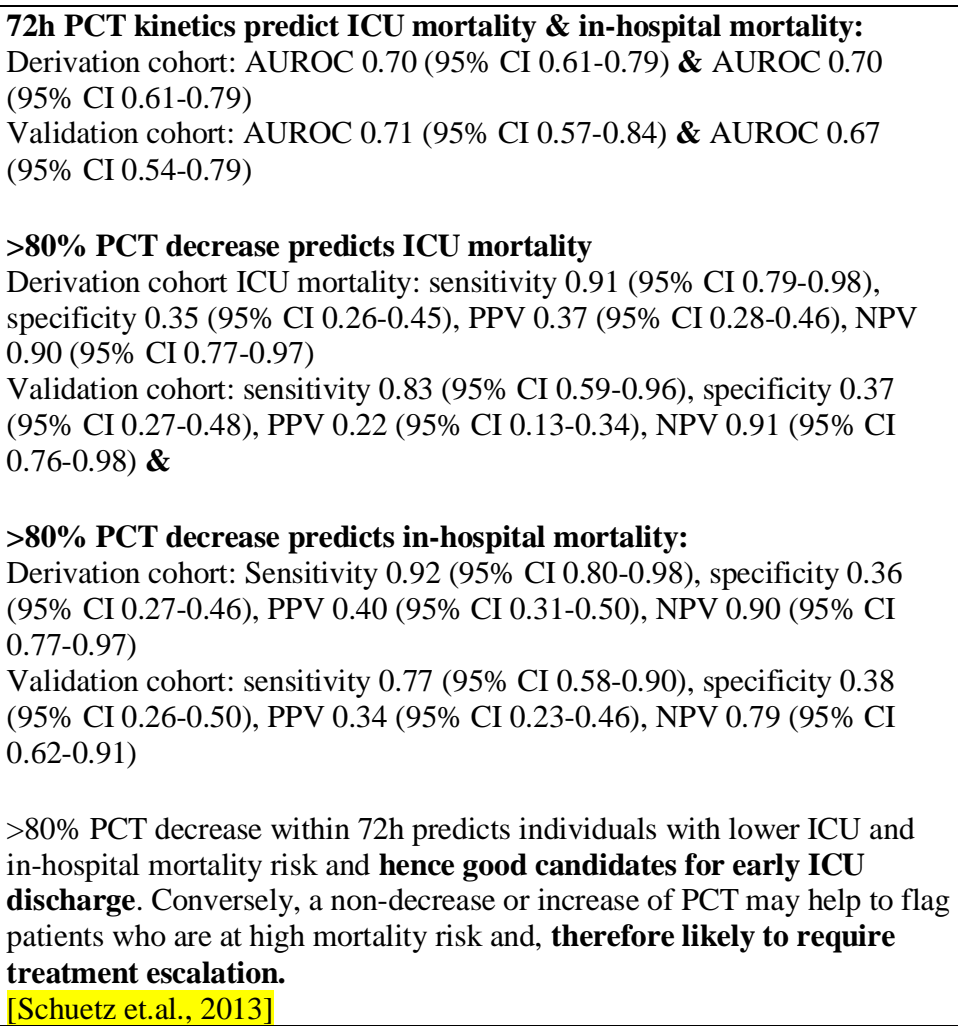 \\
\hline \multicolumn{7}{|l|}{ EMERGENCY } \\
\hline qSOFA & $\mathrm{E}$ & $\mathrm{R}$ & Retrospective & $\mathrm{N}$ & $\begin{array}{l}\text { Quick sepsis-related organ failure assessment parameters: } \\
\text { lpt each for systolic blood pressure } \leq 100 \mathrm{mmHg} \text {, respiratory } \\
\text { rate } \geq 22 \text { breaths/min, Glasgow coma scale } \leq 13\end{array}$ & $\begin{array}{l}\text { Sepsis-3 predicts: } \\
\text { ICU admission: } \mathrm{OR}=4.69(95 \% \mathrm{CI} 3.21-6.84), \mathrm{p}<0.0001 \\
\text { Need for invasive ventilation: } \mathrm{OR}=3.62(95 \% \mathrm{CI} 2.3-5.62), \mathrm{p}<0.0001 \\
\text { In-hospital mortality: } \mathrm{OR}=3.62(95 \% \mathrm{CI} 1.83-7.19), \mathrm{p}<0.001 \\
\text { [Mark et.al., 2016] }\end{array}$ \\
\hline
\end{tabular}




\begin{tabular}{|c|c|c|c|c|c|c|}
\hline $\begin{array}{c}\text { Objective } \\
\text { parameter } \\
\text { (clinical or } \\
\text { laboratory) }\end{array}$ & 氛 & 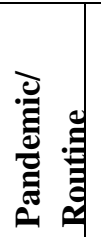 & Study design & 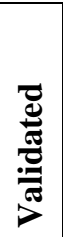 & $\begin{array}{l}\text { Specific parameters / recommended cut-off points } \\
\text { predicting poor outcome }\end{array}$ & $\begin{array}{l}\text { Prognostic performance findings/ thresholds/ } \\
\text { recommendations/ conclusions }\end{array}$ \\
\hline $\begin{array}{l}\text { Triage } \\
\text { Information } \\
\text { Mortality } \\
\text { model } \\
\text { (TIMM) }\end{array}$ & $\mathrm{E}$ & $\mathrm{R}$ & Retrospective & $\mathrm{Y}$ & $\begin{array}{l}\text { TIMM parameters: } \\
\text { Age } \\
\text { Gender } \\
\text { Arrival by ambulance } \\
\text { Triage complaint (cardiac arrest, syncope/collapse, other } \\
\text { cardiac, sepsis, other neurological, stroke/transient ischaemic } \\
\text { attack, other respiratory, malignancy, malaise) } \\
\text { ATS score (1-5) }\end{array}$ & 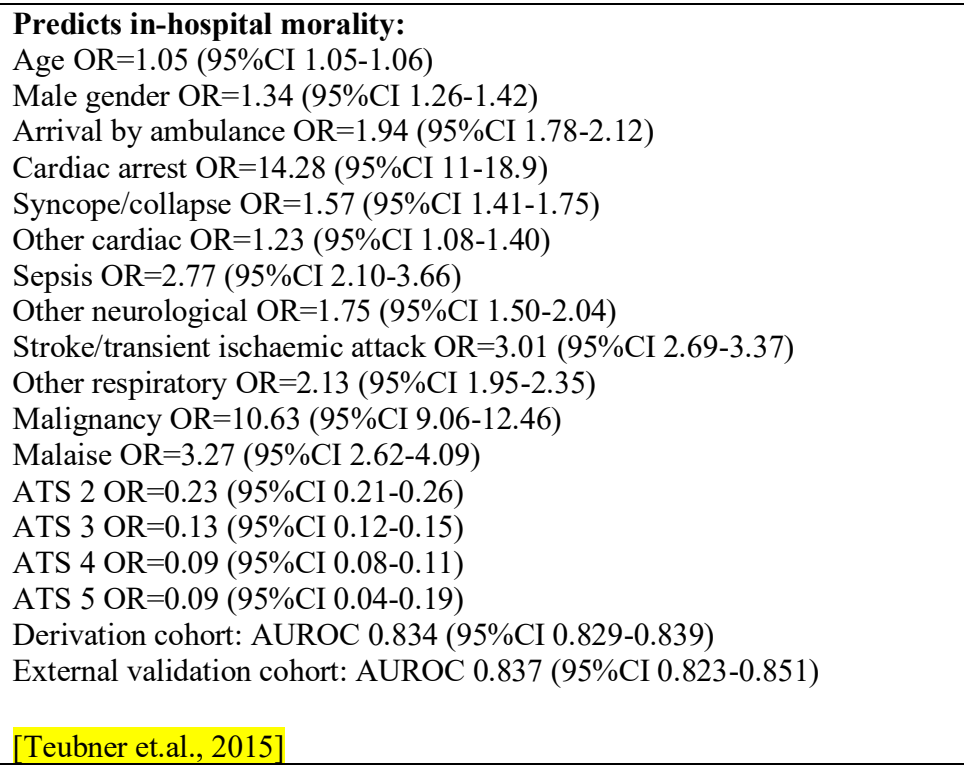 \\
\hline $\begin{array}{l}\text { SCAP score } \\
\text { Severe } \\
\text { community } \\
\text { acquired } \\
\text { pneumonia }\end{array}$ & $\mathrm{E}$ & $\mathrm{R}$ & Cohort & $\mathrm{Y}$ & $\begin{array}{l}\text { age }>80 \text { years, } \\
\text { multilobar involvement on radiography, } \\
\text { respiratory rate }>30 \text { breaths/min, } \\
\text { altered mental status } / \text { confusion (new onset) } \\
\mathrm{PaO} 2<54 \mathrm{mmHg} \text { or } \mathrm{PaO} 2 / \mathrm{FiO} 2<250 \mathrm{~mm} \mathrm{Hg}, \\
\text { decreased arterial } \mathrm{pH},<7.30 \text { ), } \\
\text { and systolic blood pressure }<90 \mathrm{~mm} \mathrm{Hg} \text {. }\end{array}$ & $\begin{array}{l}\text { Measured in ED, predictors of adverse patient-oriented outcomes } \\
\text { potentially necessitating a higher level of care } \\
\text { Major criteria for adverse outcome: } \mathrm{pH}<7.30 \mathrm{OR}=10.8(95 \% \mathrm{CI} 3.5-34.0) \\
\text { and Systolic } \mathrm{BP}<90 \mathrm{mmHg} \mathrm{OR}=8.9(95 \% \mathrm{CI} 3.2-25.2) \\
\text { Minor criteria: respiratory rate } \mathrm{OR}=12.7 \text { (95\% CI 7.7-21.0); altered mental } \\
\text { sate } \mathrm{OR}= \\
\text { Sensitivity } 92.1 \% \text { and } 84.3 \% \text { (derivation and validation); Specificity } 73.8 \% \\
\text { and } 60.3 \% \text { (derivation and validation) and AUROC } 0.38 \text { and } 0.72 \\
\text { (derivation and validation) [España } 2006 \text { ] }\end{array}$ \\
\hline
\end{tabular}




\begin{tabular}{|c|c|c|c|c|c|c|}
\hline $\begin{array}{c}\text { Objective } \\
\text { parameter } \\
\text { (clinical or } \\
\text { laboratory) }\end{array}$ & 氙 & 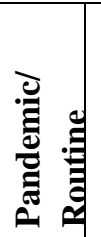 & Study design & 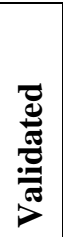 & $\begin{array}{c}\text { Specific parameters / recommended cut-off points } \\
\text { predicting poor outcome }\end{array}$ & $\begin{array}{l}\text { Prognostic performance findings/ thresholds/ } \\
\text { recommendations/ conclusions }\end{array}$ \\
\hline $\begin{array}{l}\text { Shock Index } \\
\text { (SI) }\end{array}$ & $\mathrm{E}$ & $\mathrm{R}$ & Retrospective & $\mathrm{N}$ & $\begin{array}{l}\text { (SI) is defined as the heart rate (HR) divided by systolic blood } \\
\text { pressure (SBP) in patients at risk of shock from: pulmonary } \\
\text { embolism, sepsis, etc } \\
\text { Score }>1.3 \text { increase likelihood of hospital admission } \\
\text { Score }>1.3 \text { increase likelihood of inpatient mortality } \\
\text { Score }>1.0 \text { at } 2 \text { hours post-resuscitation best death predictor } \\
\text { Score }>0.9 \text { Predicts increased risk of mortality, need for } \\
\text { massive transfusion protocol activation, and admission to ICU } \\
\text { SI }>0.8 \text { predicts requirement for vasopressors within } \mathbf{7 2} \mathbf{h r s} \\
\text { of admission }\end{array}$ & $\begin{array}{l}\text { Likelihood Ratio (+LR 6.76) } \\
\text { Likelihood Ratio (+LR 5.67) [Jalbout 2017] } \\
\text { AUROC } 0.889 \text { [95\% CI 0.805, 0.974] } \\
\text { for at least } 80 \% \text { of those identified in ED ; SI useful to anticipate need } \\
\text { for ICU and likelihood of mortality but not in isolation [Koch 2019] }\end{array}$ \\
\hline $\begin{array}{l}\text { Scoring } \\
\text { systems as } \\
\text { triage tools } \\
\text { on admission } \\
\text { to ED }\end{array}$ & $\mathrm{E}$ & $\mathrm{R}$ & $\begin{array}{l}\text { Systematic } \\
\text { Review }\end{array}$ & $\mathrm{Y}$ & $\begin{array}{l}\text { In-hospital mortality } \\
\text { Some systems used vital signs others blood tests for patients } \\
\text { admitted to a MAU or non-surgical ED or transferred to } \\
\text { hospital wards. } \\
\text { 30-day mortality } \\
\text { - } \quad \text { Mortality while admitted to ED } \\
\text { Death within } 15 \text { mins to } 24 \text { hours after arrival }\end{array}$ & $\begin{array}{ll}\text { REMS: } & \text { AUROC }=0.852(+/-0.014) \mathrm{p}<0.0001 \text { external validation } \\
\text { TTS: } & \text { AUROC }(0.657-0.782) \text { external validation } \\
\text { GS: } & \text { AUROC }=0.81(95 \% \text { CI: 0.78-0.84) } \\
\text { WPS: } & \text { AUROC }=0.74(0.74-0.77) \\
\text { EWS: } & \text { AUROC }=0.68(0.65-0.71) \\
\text { SCS: } & \text { AUROC }=0.858(\text { SE 0.009) derivation } \\
& \text { AUROC }=0.856(\text { SE 0.013) validation: } \\
\text { ALT: } & \text { AUROC }=0.904: \text { no 95\%CI provided } \\
\text { HOTEL: } & \text { AUROC }=0.865(0.793-0.937) \text { derivarion } \\
& \text { AUROC }=0.854(0.746-0.962) \text { validation: }[\text { Braband 2010] }\end{array}$ \\
\hline $\begin{array}{l}\text { Mortality in } \\
\text { Emergency } \\
\text { Department } \\
\text { Sepsis } \\
\text { (MEDS) } \\
\text { score }\end{array}$ & $\mathrm{E}$ & $\mathrm{R}$ & $\begin{array}{l}\text { Retrospective } \\
\text { case control }\end{array}$ & $\mathrm{Y}$ & $\begin{array}{l}\text { Terminal illness ( }<30 \text { days) }-6 \text { points } \\
\text { Tachypnoea (respiratory rate }>20 \text { ) or hypoxia (oxygen } \\
\text { saturation }<90 \% \text { or need for oxygen saturation of } 40 \% \mathrm{FiO} 2 \text { or } \\
\text { higher to maintain adequate saturation) }-3 \text { points } \\
\text { Septic shock }-3 \text { points } \\
\text { Platelets }<150,000 / \mathrm{mm}^{3}-3 \text { points } \\
\text { Bands }>5 \%-3 \text { points } \\
\text { Age }>65-3 \text { points } \\
\text { Lower respiratory tract infection }-2 \text { points } \\
\text { Nursing home resident }-2 \text { points } \\
\text { Altered mental status }-2 \text { points }\end{array}$ & $\begin{array}{l}\text { MEDS score predicts clinical deterioration (i.e. requiring a critical care } \\
\text { consult, ICU admission, or death) at: } \\
48-72 \text { hours before clinical deterioration event - AUROC } 0.71(95 \% \mathrm{CI} \\
0.64-0.78) \\
0-12 \text { hours before clinical deterioration event - AUROC } 0.74(95 \% \mathrm{CI} \\
0.70-0.78) \\
\text { [Yu 2014] }\end{array}$ \\
\hline
\end{tabular}




\begin{tabular}{|c|c|c|c|c|c|c|}
\hline $\begin{array}{c}\text { Objective } \\
\text { parameter } \\
\text { (clinical or } \\
\text { laboratory) }\end{array}$ & 营 & 异 & Study design & 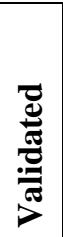 & $\begin{array}{c}\text { Specific parameters / recommended cut-off points } \\
\text { predicting poor outcome }\end{array}$ & $\begin{array}{l}\text { Prognostic performance findings/ thresholds/ } \\
\text { recommendations/ conclusions }\end{array}$ \\
\hline $\begin{array}{l}\text { IDSA/ATS } \\
\text { criteria on } \\
\text { admission }\end{array}$ & $\mathrm{E}$ & $\mathrm{R}$ & $\begin{array}{l}\text { Retrospective } \\
\text { study }\end{array}$ & $\mathrm{Y}$ & $\begin{array}{l}\text { Community acquired pneumonia: } \\
\text { IDSA/ATS } 2007 \text { criteria for severe pneumonia: } \\
\text { Minor criteria } \\
\text { Respiratory rateb }>=30 \text { breaths } / \mathrm{min} \\
\mathrm{PaO} 2 / \mathrm{FiO} 2 \text { ratio }<=250 \\
\text { Multilobar infiltrates } \\
\text { Confusion/disorientation } \\
\text { Uremia (BUN level, }>=20 \mathrm{mg} / \mathrm{dL} \text { ) } \\
\text { Leukopeniac (WBC count, }<4000 \text { cells } / \mathrm{mm} 3 \text { ) } \\
\text { Thrombocytopenia (platelet count, }<100,000 \text { cells } / \mathrm{mm} 3 \text { ) } \\
\text { Hypothermia (core temperature, }<36 \mathrm{C} \text { ) } \\
\text { Hypotension requiring aggressive fluid resuscitation } \\
\text { Major criteria } \\
\text { Invasive mechanical ventilation } \\
\text { Septic shock with the need for vasopressors } \\
\text { Ward triage to ICU within } 72 \text { hours } \\
\text { IDSA/ATS score } \geq 3 \text { at admission in the ED triaged to the ward } \\
\text { Initial Ward Triage vs. Initial ICU Triage on } 30 \text {-day mortality }\end{array}$ & $\begin{array}{l}\mathrm{OR}=2.6, \mathrm{p}=0.056 \text { 30-day mortality } \\
\mathrm{OR}=4.0, \mathrm{p}=0.08 \text { mortality } \\
\mathrm{OR}=2.495 \% \text { CI } 0.95-5.9, \mathrm{p}=0.06 \text { [Brown 2012] }\end{array}$ \\
\hline $\begin{array}{l}\text { Simple } \\
\text { Clinical Score } \\
\text { (SCS) }\end{array}$ & $\mathrm{E}$ & $\mathrm{R}$ & Prospective & $\mathrm{Y}$ & $\begin{array}{l}\text { Age } 75+\text {, Coma, oxygen saturation }<90 \% \text {, respiratory rate } \\
>30 / \text { min or breathlessness, systolic blood pressure } \leq 70 \text {, Pulse }> \\
\text { systolic BP, new stroke, Altered mental status (agitated, } \\
\text { confused, fluctuating level of consciousness), nursing home } \\
\text { residency, unable to stand unaided, prior illness keeping patient } \\
\text { some part of day in bed, diabetes type } 1 \text { or } 2 \text {, abnormal ECG, } \\
\text { Temperature }<35 \mathrm{C} \text { or } \geq 39 \mathrm{C} \\
\text { SCS can be used to stratify patients into } 5 \text { groups with very low } \\
\text { to very high risk profiles }\end{array}$ & $\begin{array}{l}\text { Weighted SCS score } \geq 12 \text { points indicates very high risk patients; } 8 \text {-11 high } \\
\text { risk of death from the first to the } 30 \text { th day after admission. } \\
\text { Most significant adjusted predictors of } 30 \text {-day mortality: Coma, new } \\
\text { stroke, temperature }<35 \mathrm{C} \text { or } \geq 39 \mathrm{C} \text {, inability to stand unaided, \& abnormal } \\
\text { ECG } \\
\text { AUROC } 0.858 \text { derivation (SE } 0.009 \text { ) and } 0.856 \text { (SE } 0.013 \text { ) validation } \\
\text { [Kellett } 2006 \text { ] } \\
\text { Applicability for early identification of patients with a high risk of death, } \\
\text { who will require care in critical care areas (or specialist palliative care) } \\
\text { [Subbe } 2010\end{array}$ \\
\hline
\end{tabular}




\begin{tabular}{|c|c|c|c|c|c|c|}
\hline $\begin{array}{c}\text { Objective } \\
\text { parameter } \\
\text { (clinical or } \\
\text { laboratory) }\end{array}$ & 氞 & 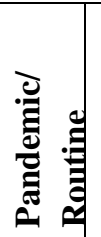 & Study design & 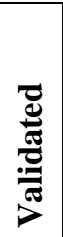 & $\begin{array}{c}\text { Specific parameters / recommended cut-off points } \\
\text { predicting poor outcome }\end{array}$ & $\begin{array}{l}\text { Prognostic performance findings/ thresholds/ } \\
\text { recommendations/ conclusions }\end{array}$ \\
\hline $\begin{array}{l}\text { Emergency } \\
\text { Severity } \\
\text { Index (ESI) } \\
\text { for triaging } \\
\text { older patients }\end{array}$ & $\mathrm{E}$ & $\mathrm{R}$ & $\begin{array}{l}\text { Prospective } \\
\text { cohort study }\end{array}$ & $\mathrm{Y}$ & $\begin{array}{l}\text { Age } \geq 65 \text { years } \\
\text { Association of ESI with mortality (ESI level } 2 \text { vs 1) } \\
\text { (ESI level } 3 \text { vs } 2 \text { ) } \\
\text { Admission to an ICU } \\
\text { ESI (level 1) diagnostic accuracy to predict life-saving } \\
\text { interventions } \\
\text { ESI 5-level triage tool (Level 1): } \\
\text { Stability of vital functions (ABCs): Unstable } \\
\text { Life threat or organ threat: Obvious } \\
\text { Requires resuscitation: Immediately } \\
\text { Severe pain or severe distress: Yes } \\
\text { Expected resource intensity: max - staff at bedside } \\
\text { continuously; mobilisation of outside resources } \\
\text { Physician/staff response: immediate team effort } \\
\text { Expected time disposition: } 1.5 \mathrm{hr}\end{array}$ & $\begin{array}{l}\mathrm{HR}=0.128(95 \% \mathrm{CI} 0.03 \text { to } 0.52) \\
\mathrm{HR}=0.309(95 \% \mathrm{CI} 0.09 \text { to } 1.01) \\
\text { Age }>=65 \text { years } \\
\text { AUROC }=0.7490(95 \% \mathrm{CI} 0.727 \text { to } 0.770) \\
\text { Sensitivity }=0.462(95 \% \text { CI } 0.232 \text { to } 0.709) \\
\text { Specificity }=0.998(95 \% \text { CI } 0.989 \text { to } 1.000) \\
\text { [Grossmann } 2012 \text { ] }\end{array}$ \\
\hline $\begin{array}{l}\text { Criteria for } \\
\text { screening and } \\
\text { triaging to } \\
\text { appropriate } \\
\text { alternative } \\
\text { care }\end{array}$ & $\mathrm{E}$ & $\mathrm{R}$ & Prospective & $\mathrm{Y}$ & $\begin{array}{l}\text { Age } 65+\text { years; frailty as CFS }>5 ; \text { meets } \geq 2 \text { calling criteria for } \\
\text { rapid response (oxygen saturation }<90 \% \text {, respiratory rate } \\
<5 / \text { min or }>30 / \text { min, loss of consciousness, prolonged or repeat } \\
\text { seizures, hypoglycaemia } 1.0-4.0 \mathrm{mmol} / \mathrm{L} \text {, low urinary output } \\
\text { ( }<15 \mathrm{ml} / \mathrm{hour} \text { or }<0.5 \mathrm{ml} / \mathrm{kg} / \text { hour); nursing home resident; } \\
\text { previous emergency hospitalisation in past year; previous ICU } \\
\text { admission in past year; either of } 7 \text { conditions: advanced cancer, } \\
\mathrm{HCF} \text {, CKD, COPD, stroke, history of myocardial infarction; } \\
\text { chronic liver disease, cognitive impairment; chronic ECG } \\
\text { abnormality; proteinuria (++ or }>30 \mathrm{mg} \text { albumin } / \mathrm{g} \text { creatinine ); } \\
\text { polypharmacy } \geq 6 \text { prescribed medications; history of fall in the } \\
\text { past } 3 \text { months }\end{array}$ & $\begin{array}{l}\text { CriSTAL score } \geq \mathbf{6} \text { should consider goals of care discussion and } \\
\text { palliative care pathway } \\
\text { Severe cognitive impairment in the absence of a contactable surrogate } \\
\text { decision-maker on admission } \\
\text { Rule of } 1 \text { point for each of } 19 \text { risk factors. Scores of } 6+\text { indicate high risk } \\
\text { of death within 3-6 months. } \\
\text { Most statistically significant death predictors on full model: frailty, } \\
\text { advanced malignancy, nursing home residency, oxygen saturation, } \\
\text { advanced age, any mental impairment } \\
\text { AUROC } 0.809(0.761-0.857) \text { for Australia } \\
\text { AUROC } 0.794(0.755-0.837) \text { For Denmark } \\
\text { [Cardona 2018] }\end{array}$ \\
\hline
\end{tabular}




\begin{tabular}{|c|c|c|c|c|c|c|}
\hline $\begin{array}{l}\text { Objective } \\
\text { parameter } \\
\text { (clinical or } \\
\text { laboratory) }\end{array}$ & 気 & 异 & Study design & 总 & $\begin{array}{c}\text { Specific parameters / recommended cut-off points } \\
\text { predicting poor outcome }\end{array}$ & $\begin{array}{l}\text { Prognostic performance findings/ thresholds/ } \\
\text { recommendations/ conclusions }\end{array}$ \\
\hline $\begin{array}{l}\text { Advanced } \\
\text { malignancy }\end{array}$ & $\begin{array}{l}\mathrm{E} \\
\mathrm{E} \\
\mathrm{I}\end{array}$ & $\mathrm{R}$ & $\begin{array}{l}\text { Cohort } \\
\text { Cohort } \\
\text { Cohort }\end{array}$ & $\begin{array}{l}\mathrm{Y} \\
\mathrm{Y} \\
\mathrm{N}\end{array}$ & $\begin{array}{l}\text { Advanced malignancy increased risk of } 3 \text {-month mortality } \\
\text { Advanced malignancy increased risk of } 3 \text {-month mortality } \\
\text { Cancer+sepsis+Lactate } 24 \mathrm{hs} \mathrm{post-admission}\end{array}$ & $\begin{array}{l}\mathrm{OR}=4.995 \% \mathrm{CI} 2.2-10.8 \text { Australia [Cardona 2018] } \\
\mathrm{OR}=3.295 \% \mathrm{CI} 1.9-5.4 \text { Denmark [Cardona 2018] } \\
\mathrm{OR}=4.095 \% \mathrm{CI} \text { 2.7 }-5.9 \text { ICU mortality [Hajjar 2011] }\end{array}$ \\
\hline $\begin{array}{l}\text { Clinical } \\
\text { Frailty Scale }\end{array}$ & $\mathrm{E}$ & $\mathrm{R}$ & Retrospective & $\mathrm{Y}$ & $\begin{array}{l}\text { Patients aged } \geq 75 \text { years: } \\
\text { Clinical frailty score } \\
\text { Age } \\
\text { Charlson comorbidity index } \\
\text { Known history of dementia and/or current cognitive concern }\end{array}$ & $\begin{array}{l}\text { OR } 1.60(95 \% \text { CI } 1.48-1.74), p<0.001 \text {, AUROC } 0.72(95 \% \text { CI } 0.69- \\
0.75) \text { for inpatient mortality } \\
\text { OR } 1.03(95 \% \text { CI } 1.01-1.05), p=0.001 \text { for inpatient mortality } \\
\text { OR } 1.16(95 \% \text { CI } 1.12-1.20), p<0.001 \text { for inpatient mortality } \\
\text { OR } 0.66(95 \% \text { CI } 0.51-0.86), p=0.002 \text { for inpatient mortality } \\
\text { [Wallis } 2015 \text { ] }\end{array}$ \\
\hline $\begin{array}{l}\text { Frailty } \\
\text { syndromes }\end{array}$ & $\mathrm{E}$ & $\mathrm{R}$ & $\mathrm{N} / \mathrm{R}$ & $\mathrm{N}$ & $\begin{array}{l}\text { Frailty syndromes: } \\
\text { Delirium, dementia, mobility problems, pressure ulcers }\end{array}$ & $\begin{array}{l}\text { Predictors of in-patient mortality: } \\
\text { Delirium OR=1.562 (95\% CI 1.229-1.985) } \\
\text { Dementia OR=1.595 (95\% CI 1.323-1.924) } \\
\text { Mobility problems OR=1.495 (95\% CI 1.231-1.817) } \\
\text { Pressure ulcers OR=2.996 (95\% CI 2.403-3.735) } \\
\text { AUROC 0.728 (95\% CI 0.708-0.748), p<0.001 } \\
\text { [Soong et.al., 2017] }\end{array}$ \\
\hline $\begin{array}{l}\text { Routine blood } \\
\text { tests }\end{array}$ & $\mathrm{E}$ & $\mathrm{R}$ & $\begin{array}{l}\text { Prospective } \\
\text { cohort study }\end{array}$ & $\mathrm{Y}$ & $\begin{array}{l}\text { Blood test parameters: } \\
\text { Albumin, creatinine, c-reactive protein, haemoglobin, lactate } \\
\text { dehydrogenase, leukocyte, potassium, sodium } \\
\text { Demographic parameters: age }(>16) \text { and gender }\end{array}$ & $\begin{array}{l}\text { Routine blood tests + demographics predictor of 30-day mortality: } \\
\text { Derivation cohort AUROC } 0.886 \text { (95\% CI 0.861-0.911) } \\
\text { Validation cohort AUROC } 0.908 \text { (95\% CI 0.892-0.923) } \\
\text { Routine blood test should be included in early risk stratification for ED } \\
\text { physicians to prioritise patients when necessary. } \\
\text { [Kristensen et.al., 2017] }\end{array}$ \\
\hline
\end{tabular}




\begin{tabular}{|c|c|c|c|c|c|c|}
\hline $\begin{array}{l}\text { Objective } \\
\text { parameter } \\
\text { (clinical or } \\
\text { laboratory) }\end{array}$ & 己ِ & 导 & Study design & 冚 & $\begin{array}{l}\text { Specific parameters / recommended cut-off points } \\
\text { predicting poor outcome }\end{array}$ & $\begin{array}{l}\text { Prognostic performance findings/ thresholds/ } \\
\text { recommendations/ conclusions }\end{array}$ \\
\hline $\begin{array}{l}\text { Laboratory } \\
\text { only model }\end{array}$ & $\mathrm{E}$ & $\mathrm{R}$ & Retrospective & $\mathrm{Y}$ & $\begin{array}{l}\text { Standard laboratory data parameters: } \\
\text { Serum sodium, potassium, urea, albumin, red cell distribution, } \\
\text { white blood cell count } \\
\text { 30-day mortality risk-estimates subsets based on laboratory } \\
\text { data + troponin: } \\
\text { Group I: } \leq 1 \% \\
\text { Group II: }>1 \leq 2 \% \\
\text { Group III: }>2 \leq 4 \% \\
\text { Group IV: }>4 \leq 8 \% \\
\text { Group V: }>8 \%\end{array}$ & $\begin{array}{l}\text { Predicts 30-day mortality using only laboratory data }+ \text { troponin } \\
\text { Group I: OR=1.0 (reference group); } \\
\text { Group II: OR=5.1 (95\%CI 3.4-7.7); } \\
\text { Group III: OR=14.5 (95\%CI 10.1-20.8); } \\
\text { Group IV: OR=50.8 (95\%CI 36.2-71.5); } \\
\text { Group V: OR=85.5 (95\%CI 61.0-119.9) } \\
\text { Derivation cohort: AUROC 0.90 (95\%CI 0.89-0.90) } \\
\text { Validation cohort: AUROC 0.88 (95\%CI 0.86-0.90) } \\
\text { [O'Sullivan et.al., 2012] }\end{array}$ \\
\hline $\begin{array}{c}\text { Serum } \\
\text { Creatinine } \\
\text { or End-stage } \\
\text { Renal disease }\end{array}$ & $\mathrm{E}$ & $\mathrm{R}$ & $\begin{array}{l}\text { Retrospective } \\
\text { data analysis }\end{array}$ & $\mathrm{Y}$ & $\begin{array}{l}\text { Serum creatinine }>3 \mathrm{mg} / \mathrm{dL} \text { at time of continuous renal } \\
\text { replacement therapy. } \\
\text { Chronic or acute kidney disease }(\mathrm{KD}) \\
\text { CPR before admission }+\mathrm{KD} \text { requiring renal dialysis } \\
\text { CPR before admission+ KD not requiring renal dialysis }\end{array}$ & $\begin{array}{l}\text { OR=1.24 (95\%CI 1.13-1.37) for in-hospital mortality among patients on } \\
\text { chronic renal dialysis } \\
\text { Adjusted AUROC 0.853 (95\% CI 0.851-0.854) } \\
\text { OR=1.9 95\%CI 1.44-2.52 in-hospital mortality [Hutchison 2007] } \\
\text { OR=2.1 95\%CI 2.05-2.22 in-hospital mortality [Hutchison 2007] } \\
\text { This may inform the clinical decision process surrounding ICU } \\
\text { admission for patients receiving chronic dialysis therapy [Hutchison } \\
\text { 2007] }\end{array}$ \\
\hline $\begin{array}{l}\text { Arterial } \\
\text { Lactate }\end{array}$ & $\mathrm{E}$ & $\mathrm{R}$ & $\begin{array}{l}\text { Cohort } \\
\text { Cohort }\end{array}$ & $\begin{array}{l}\mathrm{N} \\
\mathrm{N}\end{array}$ & $\begin{array}{l}\text { Serum arterial lactate } \geq 3.3 \mathrm{mmol} / \mathrm{L} \text { in-hospital mortality } \\
\text { Serum arterial lactate }>4 \mathrm{mmol} / \mathrm{L}\end{array}$ & $\begin{array}{l}\mathrm{OR}=2.295 \% \mathrm{CI} \text { 1.5-3.1 post-discharge mortality [Allegretti 2013] } \\
\mathrm{OR}=4.295 \% \mathrm{CI} \text { 1.9-9.4 in-hospital mortality [Bethea 2018] }\end{array}$ \\
\hline
\end{tabular}




\begin{tabular}{|c|c|c|c|c|c|c|}
\hline $\begin{array}{c}\text { Objective } \\
\text { parameter } \\
\text { (clinical or } \\
\text { laboratory) }\end{array}$ & 氞 & 异 & Study design & 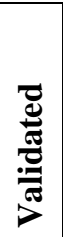 & $\begin{array}{c}\text { Specific parameters / recommended cut-off points } \\
\text { predicting poor outcome }\end{array}$ & $\begin{array}{l}\text { Prognostic performance findings/ thresholds/ } \\
\text { recommendations/ conclusions }\end{array}$ \\
\hline $\begin{array}{l}\text { Estimated } \\
\text { glomerular } \\
\text { filtration rate } \\
\text { (eGFR) }\end{array}$ & $\mathrm{E}$ & $\mathrm{R}$ & $\begin{array}{l}\text { Prospective } \\
\text { cohort }\end{array}$ & $\mathrm{Y}$ & $\begin{array}{l}\text { eGFR at time of emergency presentation, per decrease of } \\
10 \mathrm{ml} / \mathrm{min} / 1.73 \mathrm{~m} 2 \text { as calculated using the Chronic Kidney } \\
\text { Disease-Epidemiology Collaboration equation (CKD-EPI). }\end{array}$ & $\begin{array}{l}\text { OR } 1.15 \text { (95\% CI } 1.09-1.22), \mathrm{p}<0.001 \text {, AUROC } 0.71(95 \% \text { CI } 0.68 \text { - } \\
0.73) \text { for } 30 \text { day mortality } \\
\text { OR } 1.16 \text { (95\% CI } 1.08-1.24), \mathrm{p}<0.001 \text {, AUROC } 0.71 \text { (95\% CI } 0.68 \text { - } \\
0.75) \text { for in hospital mortality } \\
\text { OR } 1.15 \text { (95\% CI } 1.10-1.20), \mathrm{p}<0.001 \text {, AUROC } 0.63(95 \% \text { CI } 0.60 \text { - } \\
0.65) \text { for ICU admission } \\
\text { [Haas } 2020 \text { ] }\end{array}$ \\
\hline \multicolumn{7}{|l|}{ WARD CARE } \\
\hline $\begin{array}{l}\text { Simple } \\
\text { clinical score } \\
\text { (SCS) \& } \\
\text { HOTEL score }\end{array}$ & $\mathrm{W}$ & $\mathrm{R}$ & $\begin{array}{l}\text { Prospective } \\
\text { cohort study }\end{array}$ & $\mathrm{Y}$ & 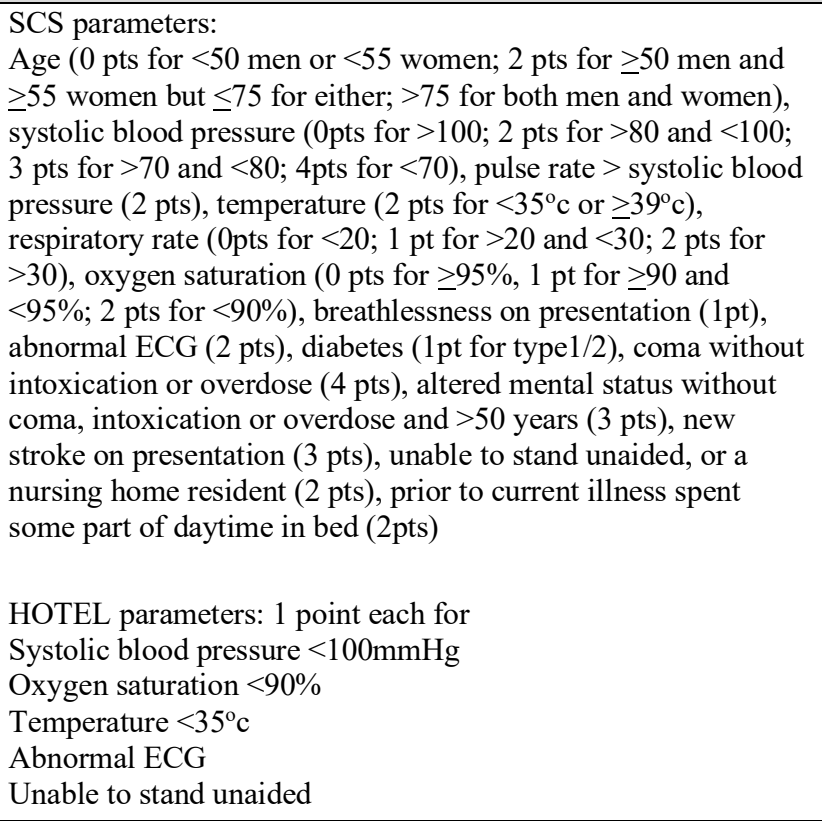 & $\begin{array}{l}\text { SCS: } \\
\text { Predicts 24h mortality: AUROC } 0.960 \text { ( } 95 \% \text { CI } 0.932-0.988), \mathrm{p}=0.998 \\
\text { Predicts 30-day mortality: AUROC } 0.826 \text { (95\% CI 0.774-0.879), p=0.947 } \\
\text { [Straede et.al., 2014] } \\
\text { HOTEL: } \\
\text { Predicts 24h mortality: AUROC } 0.931 \text { (95\% CI } 0.901-0.962), \mathrm{p}=0.234 \\
\text { [Straede et.al., 2014] }\end{array}$ \\
\hline
\end{tabular}




\begin{tabular}{|c|c|c|c|c|c|c|}
\hline $\begin{array}{l}\text { Objective } \\
\text { parameter } \\
\text { (clinical or } \\
\text { laboratory) }\end{array}$ & 突 & 兽 & Study design & 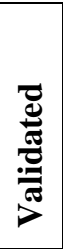 & $\begin{array}{c}\text { Specific parameters / recommended cut-off points } \\
\text { predicting poor outcome }\end{array}$ & $\begin{array}{l}\text { Prognostic performance findings/ thresholds/ } \\
\text { recommendations/ conclusions }\end{array}$ \\
\hline $\begin{array}{l}\text { NIVO score } \\
\text { Non-invasive } \\
\text { ventilation } \\
\text { outcomes }\end{array}$ & W & $\mathrm{R}$ & Retrospective & $\mathrm{Y}$ & $\begin{array}{l}\text { Atrial fibrillation, chest } X \text {-ray consolidation, } \mathrm{pH}<7.25 \text {, } \\
\text { Glasgow coma scale } \leq 14 \text { (all } 1 \text { point), timing of acidaemia }>12 \\
\text { hours from admission time ( } 2 \text { points) and eMRCD }(1-4=0 \text {, } \\
5 \mathrm{a}=2,5 \mathrm{~b}=3) \text {. }\end{array}$ & $\begin{array}{l}\text { For exacerbations of COPD and respiratory acidaemia requiring assisted } \\
\text { ventilation: } \\
\text { Maximum score of } 9 \text { using } 6 \text { indices. Higher score=increased in-hospital } \\
\text { mortality } \\
\text { AUROC in derivation cohort: } 0.83 \text {; in validation cohort }=0.79 \\
\text { Useful for guiding level of care, setting treatment limitations and } \\
\text { objectifying both clinician decision making and discussion with } \\
\text { patients/family members. [Hartley } 2019 \text { ] }\end{array}$ \\
\hline $\begin{array}{l}\text { HOMR } \\
\text { Hospital } \\
\text { patient 1-year } \\
\text { mortality risk }\end{array}$ & W & $\mathrm{R}$ & Retrospective & $\mathrm{Y}$ & $\begin{array}{l}\text { age, sex and living status); health burden (measured using the } \\
\text { Charlson Comorbidity Index score, home oxygen status and the } \\
\text { number of visits to emergency departments and admissions to } \\
\text { hospital by ambulance in the previous year); and acuity of } \\
\text { illness (admission urgency and hospital service, direct } \\
\text { admission to an intensive care unit and whether the admission } \\
\text { was an urgent readmission to hospital). }\end{array}$ & $\begin{array}{l}\text { Risk of 1-year mortality: } 8.7 \%(95 \% \mathrm{CI} 8.7-8.8) \\
\text { AUROC range } 0.89(95 \% \mathrm{CI} 0.87-0.91) \text { to AUROC } 0.92(95 \% \mathrm{CI} 0.91- \\
0.93) \text { in } 3 \text { validation cohorts } \\
\text { [van Walraven } 2015 \text { ] }\end{array}$ \\
\hline $\begin{array}{l}\text { CURB } 65 \\
\text { score }\end{array}$ & $\mathrm{E}$ & $\mathrm{R}$ & $\begin{array}{l}\text { Cohort } \\
\text { Cohort } \\
\text { Cohort } \\
\text { Cohort }\end{array}$ & Y & $\begin{array}{l}\text { Six point score, one point for each of Confusion, Urea }>7 \\
\mathrm{mmol} / \mathrm{l} \text {, Respiratory rate }>30 / \mathrm{min} \text {, low systolic }(<90 \mathrm{~mm} \mathrm{Hg} \text { ) or } \\
\text { diastolic ( }<60 \mathrm{~mm} \mathrm{Hg} \text { ) Blood pressure), age }>65 \text { years }\end{array}$ & $\begin{array}{l}\text { 30-day mortality : score } 4=41.5 \% \text { mortality and score } 5=57 \% \\
\text { CURB-65 } \geq 3 \text { specificity } 74.9 \% \text { derivation and } 74.7 \% \text { validation [Lim WS } \\
\text { 2003] } \\
\text { CURB-65 } \geq 3 \text { Sensitivity } 38.5 \text { (95\%CI } 28.4-49.2) \text { Specificity } 74.2 \\
\text { (95\%CI } 71.0-77.2 \text { ) and AUROC } 0.62(95 \% \text { CI } 0.56-0.67 \text { ) [Charles } 2008 \text { ] } \\
\text { CURB-65 } \geq 3 \text { Sensitivity } 68.4 \% \text { and } 60.3 \% \text { (derivation and validation); } \\
\text { Specificity } 86.8 \% \text { and } 78.4 \% \text { (derivation and validation) and AUROC } \\
0.78 \text { and } 0.69 \text { (derivation and validation) [España } 2006 \text { ] } \\
\text { CURB65 } \geq 3 \text { predicts } 30-\text { day mortality from sepsis onset: } \\
\text { OR=30.3 (95\%CI } 6.17-66.87) \\
\text { AUROC } 0.72 \text { (95\% CI } 0.67-0.77) \\
\text { Sensitivity } 81 \%, \text { specificity } 52 \%, \text { PPV } 29 \%, \text { NPV } 92 \% \\
\text { [Marwick et.al., 2014] }\end{array}$ \\
\hline
\end{tabular}




\begin{tabular}{|c|c|c|c|c|c|c|}
\hline $\begin{array}{c}\text { Objective } \\
\text { parameter } \\
\text { (clinical or } \\
\text { laboratory) }\end{array}$ & 氞 & 异兽 & Study design & 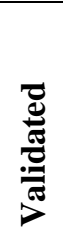 & $\begin{array}{c}\text { Specific parameters / recommended cut-off points } \\
\text { predicting poor outcome }\end{array}$ & $\begin{array}{c}\text { Prognostic performance findings/ thresholds/ } \\
\text { recommendations/ conclusions }\end{array}$ \\
\hline $\begin{array}{l}\text { Mortality } \\
\text { Predictive } \\
\text { Model for } \\
\text { Children }\end{array}$ & $\mathrm{W}$ & $\mathrm{R}$ & Retrospective & $\mathrm{Y}$ & $\begin{array}{l}\text { Laboratory parameters for children }(2-17 \mathrm{y}) \\
\text { Albumin } \leq 2.8 \mathrm{~g} / \mathrm{dL} \\
\text { Aspartate aminotransferase }>55 \mathrm{U} / \mathrm{L} \\
\text { Creatinine }>0.8 \mathrm{mg} / \mathrm{dL} \\
\text { Glucose }>300 \mathrm{mg} / \mathrm{dL} \\
\text { Sodium } \leq 130 \text { or } \geq 142 \mathrm{mEq} / \mathrm{L} \\
\text { Arterial } \mathrm{pH} \leq 7.35 \text { or }>7.45 \mathrm{pH} \text { units } \\
\text { PaCO }>60 \mathrm{mmHg} \\
\text { Haemoglobin } \leq 10 \mathrm{~g} / \mathrm{dL} \\
\text { Platelets } \leq 150 \mathrm{x} 10^{9} / \mathrm{L} \\
\text { Vital signs \& altered mental status: } \\
\text { Oral temperature } \leq 95^{\circ} \mathrm{F} \\
\text { Pulse }>120 \mathrm{bpm} \\
\text { SBP } \leq 80 \text { or }>150 \mathrm{mmHg} \\
\text { Mild or moderate altered mental status } \\
\text { Severe altered mental status }\end{array}$ & 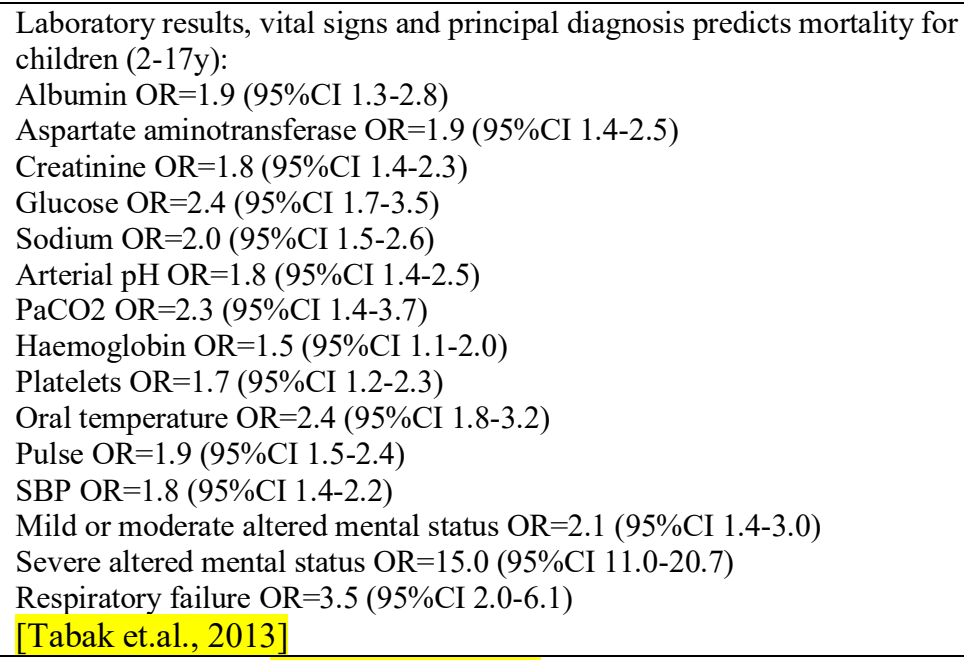 \\
\hline $\begin{array}{l}\text { Age as } \\
\text { Included in } \\
\text { several } \\
\text { algorithms }\end{array}$ & $\begin{array}{c}\mathrm{I} \\
\mathrm{E} \\
\mathrm{E} \\
\mathrm{W} \\
\mathrm{E} \\
\mathrm{I}\end{array}$ & $\mathrm{R}$ & $\begin{array}{l}\text { Cohort } \\
\text { Retrospective } \\
\text { Retrospective } \\
\text { Prospective } \\
\text { Cohort } \\
\text { Guidelines and } \\
\text { Consensus }\end{array}$ & $\begin{array}{l}\mathrm{N} \\
\mathrm{Y} \\
\mathrm{Y} \\
\mathrm{Y} \\
\mathrm{Y}\end{array}$ & $\begin{array}{l}\geq 85 \text { years predicts ICU mortality } \\
\geq 80 \text { years predicts high severity requiring higher resources } \\
\geq 75 \text { years } \& \geq 65 \text { years predict need for IVU and MV } \\
\geq 65 \text { years predicts } 30 \text {-day mortality } \\
\geq 65 \text { years in-hospital or post-discharge mortality } \\
\geq 65 \text { years overall mortality } \\
\geq 65 \text { years in-hospital mortality }\end{array}$ & $\begin{array}{l}\mathrm{OR}=1.8, \mathrm{p}<0.001 \text { [Brunner Ziegler 2007] } \\
\mathrm{OR}=2.495 \% \text { CI } 1.3 \text { to } 4.4 \text { [España 2006] } \\
\mathrm{OR}=4.4(2.7-7.2) \& \text { OR=3.0 (1.7-5.5) respectively [Talmor 2007] } \\
\mathrm{OR}=3.595 \% \text { CI } 1.6 \text { to } 8.0 \text { [Lim WS 2003] } \\
\mathrm{OR}=1.0595 \% \text { CI } 1.02-1.08 \text { Denmark [Cardona 2018] } \\
\text { Age not per se, but in conjunction with chronic conditions to maximise } \\
\text { life-years saved rather than lives. [Powell NY 2008, Brunner Ziegler 2007, } \\
\text { Daugherty-Biddison } 2019 \\
\text { OR=6.5 95\% CI } 3.8 \text { to } 11.2 \text { [Hough 2015] } \\
\text { Age and Shock Index better predictors of in-hospital death than SBP [Koch } \\
\text { 2019] }\end{array}$ \\
\hline \multicolumn{7}{|c|}{ 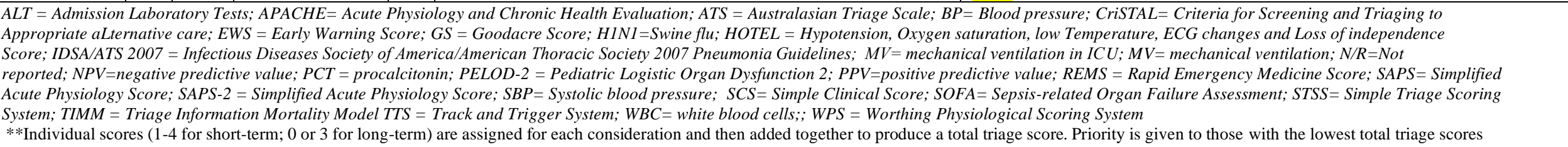 } \\
\hline
\end{tabular}

